Praca na stopień doktora nauk medycznych wykonana $\mathrm{w}$

Katedrze i Klinice Chorób Uszu, Nosa, Gardła i Krtani GUMed

Kierownik: prof. dr hab. med. Czesław Stankiewicz.

\title{
Dominik Stodulski
}

Rak ślinianki przyusznej: analiza kliniczno-patologiczna oraz ocena wyników leczenia

Promotor: prof. dr hab. med. Czesław Stankiewicz 
Składam serdeczne podziękowania

Panu Profesorowi Czesławowi Stankiewiczowi za życzliwość i pomoc przy realizacji pracy, Moim Koleżankom i Kolegom za cenne wskazówki, Mojej Żonie za wsparcie i niewyczerpanq cierpliwość. 


\section{SPIS TREŚCI}

1. Wstęp............................................................4

1.1. Epidemiologia nowotworów złośliwych ślinianki przyusznej.............4

1.2. Klasyfikacja histologiczna guzów gruczołów ślinowych i jej ewolucja......7

1.3. Omówienie cech histologicznych i klinicznych raków gruczołów ślino-

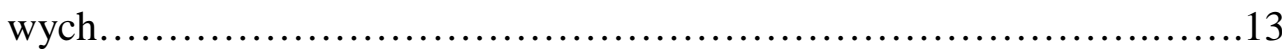

1.4. Zasady klasyfikacji klinicznej raków dużych gruczołów ślinowych.........20

1.5. Metody i wytyczne dotyczące leczenia raków ślinianki przyusznej.........24

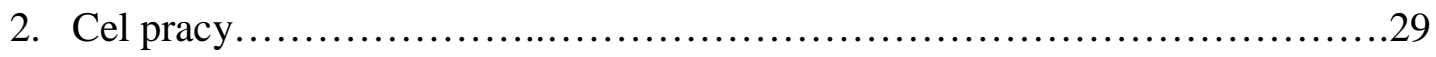

3. Materiał i metoda ........................................................ 30

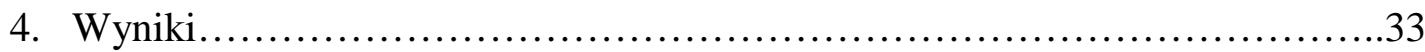

4.1. Dane kliniczno-patologiczne..................................... 33

4.2. Sposób leczenia.................................................42

4.3. Wyniki leczenia...............................................49

4.4. Niepowodzenie leczenia...........................................78

5. Omówienie............................................................ 83

5.1. Dane kliniczno-patologiczne...................................... 83

5.2. Sposób leczenia...............................................98

5.3. Wyniki leczenia oraz wartość rokownicza wybranych czynników........100

5.4. Niepowodzenie leczenia.........................................105

6. Wnioski............................................................. 111

7. Streszczenie.............................................................. 113

8. Summary............................................................ 117

9. Piśmiennictwo..................................................... 120 


\section{WSTĘP}

Rak ślinianki przyusznej należy do najbardziej heterogenicznych pod względem budowy histologicznej i przebiegu klinicznego nowotworów występujących u człowieka. Mimo stałego postępu w diagnostyce i leczeniu stanowi on, głównie z powodu swojej względnej rzadkości, duże wyzwanie dla onkologów i chirurgów głowy i szyi.

\subsection{Epidemiologia nowotworów złośliwych ślinianki przyusznej}

Guzy gruczołów ślinowych są rzadkie, stanowią 2 - 3\% wszystkich nowotworów głowy i szyi. Większość (64 do 80\%) nowotworów gruczołów ślinowych zlokalizowana jest w śliniance przyusznej, najczęściej w płacie powierzchownym, z czego guzy złośliwe stanowią około $15 \%$ [27, 31, 32, 90, cyt. wg 118]. Surowy współczynnik zachorowań na nowotwory złośliwe dużych gruczołów ślinowych w Polsce wynosi 0,8/100000 dla mężczyzn i 0,7 dla kobiet, co stanowi $0,2 \%$ wszystkich nowotworów złośliwych u mężczyzn i 0,3\% u kobiet [cyt. wg 12]. Według danych WHO, częstość występowania nowotworów złośliwych dużych gruczołów ślinowych jest podobna na całym świecie, chociaż istnieją populacje o znacznie wyższym współczynniku zachorowań (np. lymphoepithelial carcinoma gruczołów ślinowych u Eskimosów Ameryki Północnej). Kobiety chorują nieco częściej na nowotwory złośliwe ślinianek, jednakże istnieje zależność między poszczególnymi rodzajami raków a płcią. Średni wiek chorych ze złośliwymi nowotworami gruczołów ślinowych wynosi 47 lat, a szczyt zachorowań obserwowany jest między 6 i 7 dekadą życia [5]. 
Jak udowodniono, czynnikiem etiologicznym w rozwoju lymphoepithelial carcinoma może być zakażenie wirusem Epsteina Barra (EBV) [89, 113]. Inne patogeny, takie jak wirus brodawczaka ludzkiego (HPV), poliomawirusy wydają się nie odgrywać żadnej roli w rozwoju tych nowotworów [59]. Udowodniono natomiast, że promieniowanie jonizujące ma związek z rozwojem nowotworów łagodnych i złośliwych gruczołów ślinowych. U osób, które przeżyły wybuch bomby atomowej w Hiroshimie lub Nagasaki ryzyko rozwoju złośliwego nowotworu ślinianek było 11 razy większe w porównaniu z mieszkańcami innych miast Japonii [8, 108]. Również przebyte napromienianie regionu głowy i szyi z powodu innych nowotworów oraz leczenie jodem radioaktywnym z powodu chorób tarczycy, a także częste wykonywanie zdjęć rentgenowskich zębów związane są ze wzrostem ryzyka raka gruczołów ślinowych $[46,62,65,84,87]$. W piśmiennictwie światowym istnieją ponadto doniesienia na temat związku ekspozycji na promieniowanie ultrafioletowe $\mathrm{z}$ występowaniem guzów dużych gruczołów ślinowych [103]. Nie udowodniono natomiast związku między rozwojem tych nowotworów a promieniowaniem mikrofalowym (telefony komórkowe, kuchenki) lub ekspozycją na radon [4, 49, 64]. Wykazano, że istnieje zwiększone ryzyko zachorowań na nowotwory gruczołów ślinowych związane z rodzajem wykonywanej pracy (przemysł gumowy, samochodowy, ekspozycja na nikiel, chrom, pył cementowy i/lub azbestowy oraz pracownicy salonów fryzjerskich) $[47,58,63]$. Nie wykazano związku między rozwojem złośliwych nowotworów gruczołów ślinowych a paleniem tytoniu oraz konsumpcją alkoholu, jednakże konieczne są dalsze badania na większych grupach chorych [49, 66, 88,119]. Nie wyjaśniony jest również wpływ hormonów płciowych (estrogenów, prostagenów i androgenów) na rozwój nowotworów gruczołów ślinowych [23, 24]. 
Największe zestawienia (2062 i 396 przypadków) nabłonkowych nowotworów złośliwych ślinianki przyusznej, opracowane na podstawie danych zebranych w Szwedzkim Krajowym Rejestrze Nowotworów, przedstawili Wahlberg i wsp. oraz Eneroth i wsp. [31, 116]. Na uwagę zasługuje też materiał 85 raków ślinianki przyusznej u chorych wyłącznie poniżej 18 roku życia opublikowany przez Shapiro i wsp. [93]. W tabeli I zebrano prace dotyczące nowotworów złośliwych dużych gruczołów ślinowych z podaniem liczby przypadków pierwotnych raków ślinianki przyusznej.

Tabela I.

Rak ślinianki przyusznej w piśmiennictwie światowym

\begin{tabular}{lllc}
\hline Autor & Kraj & Rok & Liczba chorych \\
\hline Wahlberg P. i wsp. [116] & Szwecja & 2002 & 2062 \\
Eneroth C.M. i wsp. [31] & Szwecja & 1971 & 396 \\
Armstrong J.G. i wsp. [3] & USA & 1992 & 386 \\
Terhaard C. i wsp. [109] & Holandia & 2006 & 324 \\
Theriault C. i wsp. [112] & Kanada & 1986 & 271 \\
Carrillo J.F. i wsp. [16] & Meksyk & 2007 & 127 \\
Lima R.A. i wsp. [55] & Brazylia & 2005 & 126 \\
Kelley D.J. i wsp. [50] & USA & 1996 & 121 \\
Pedersen D. i wsp. [77] & Dania & 1992 & 110 \\
Witten J. i wsp. [120] & Dania & 1990 & 105 \\
Huang C.C. i wsp. [48] & Tajwan & 2007 & 88 \\
Shapiro N.L. i wsp. [93] & USA & 2005 & 85 \\
Matsuba H.M. i wsp. [60] & USA & 1985 & 79 \\
Rafla S. i wsp. [85] & USA & 1977 & 67 \\
Tullio A. i wsp. [114] & Włochy & 2001 & 45 \\
\hline
\end{tabular}

W polskim piśmiennictwie otolaryngologicznym i onkologicznym można również 
znaleźć doniesienia i zestawienia omawiające nowotwory ślinianki przyusznej, jednakże materiał dotyczący raków jest niezbyt liczny. Największe polskie zestawienia przedstawia tabela II.

Tabela II.

Nowotwory złośliwe ślinianki przyusznej w piśmiennictwie polskim

\begin{tabular}{lcc}
\hline Autor & Rok & Liczba chorych \\
\hline Gierek T. (Katowice) [35] & 2007 & 106 \\
Ożdziński W. (Gdańsk) [76] & 1995 & 72 \\
Olszański W. (Lublin) [74] & 2000 & 64 \\
Pietniczka-Załęska M. (Warszawa) [79] & 2008 & 60 \\
Dalke K. (Bydgoszcz) [21] & 1995 & 42 \\
Bień S. (Kielce) [11] & 1999 & 39 \\
\hline
\end{tabular}

\subsection{Klasyfikacja histologiczna guzów gruczołów ślinowych i jej ewolucja}

W przypadku guzów gruczołów ślinowych należy rozważyć trzy możliwości ich pochodzenia: sialoma (sialadenoma) są to nowotwory wywodzące się z miąższu; synsialoma (synsialadenoma) to guzy rozwijające się wewnątrz torebki ślinianki, ale pochodzące ze zrębu, tj. z tkanki łącznej włóknistej, tłuszczowej, naczyń, nerwów. Parasialoma (parasialadenoma) są nowotworami pochodzącymi z tkanek otaczających ślinianki, które mogą manifestować się jako guzy gruczołów ślinowych. Guzy wywodzące się z miąższu gruczołu ślinowego (sialoma) są najczęstsze i najważniejsze ze wszystkich nowotworów obejmujących tę strukturę. Obecna klasyfi- 
kacja guzów wywodzących się z miąższu gruczołów ślinowych opiera się na ich cechach morfologicznych, cytologicznych i biologicznych (klinicznych) [57].

Klasyfikacja histologiczna guzów gruczołów ślinowych podlega ciagłej ewolucji. Do wczesnych lat 50-tych XX wieku, ze względu na brak publikacji zawierających duży materiał operacyjny nowotworów gruczołów ślinowych, trudno było stworzyć klasyfikację histologiczną tych guzów, która korespondowałaby z ich przebiegiem klinicznym [29]. W 1954 roku Foote i Frazell zaprezentowali klasyfikację, która była pierwszą opartą na dużym materiale klinicznym i zdecydowanie rozdzielała nowotwory łagodne od złośliwych [33]. W 1972 roku została opracowana przez Światową Organizację Zdrowia klasyfikacja histologiczna guzów gruczołów ślinowych z uniwersalną i powszechnie akceptowaną nomenklaturą.

Tabela III

Histologiczna klasyfikacja guzów gruczołów ślinowych (WHO, 1972) [111]

I . Nabłonkowe (epithelial)

A. Gruczolak (adenoma)

B. Guz śluzowo-naskórkowy (mucoepidermoid tumour)

C. Guz zrazikowokomórkowy (acinic cell tumour)

D. Rak (carcinoma)

1. Rak gruczołowo-torbielowaty (adenoid cystic carcinoma)

2. Gruczolakorak (adenocarcinoma)

3. Rak płaskonabłonkowy (squamous cell carcinoma)

4. Rak niezróźnicowany (undifferenciated carcinoma)

5. Rak w gruczolaku wielopostaciowym (carcinoma ex pleomorphic adenoma)

II. Nienabłonkowe (non-epithelial)

III. Niesklasyfikowane (unclassified)

IV. Stany pokrewne (allied conditions)

Według niej, guzy gruczołów ślinowych zostały podzielone na cztery główne grupy: nabłonkowe, nienabłonkowe, niesklasyfikowane i stany pokrewne. Prawdziwe nowotwory gruczołów ślinowych (sialoma) należały do pierwszej grupy i były podzielone na cztery podgrupy: gruczolaki, guzy śluzowo-naskórkowe, guzy zrazikowokomórkowe i różnego rodzaju raki. Guzy śluzowo-naskórkowe oraz guzy zraziko- 
wokomórkowe zostały wyodrębnione jako osobne podgrupy ze względu na dwoisty obraz histologiczny i przebieg kliniczny (łagodniejszy oraz zdecydowanie agresywny). W podgrupie raków wyróżniono 5 rodzajów (rak gruczołowo-torbielowaty, gruczolakorak, rak płaskonabłonkowy, rak niezróżnicowany oraz rak w gruczolaku wielopostaciowym), a więc klasyfikacja WHO z 1972 roku prezentowała łącznie 7 różnych typów nabłonkowych nowotworów złośliwych [29, 111]. W związku z osiągnięciami w badaniach nad patologią nowotworów gruczołów ślinowych rozpoczęto w 1987 roku prace nad drugą edycją histologicznej klasyfikacji WHO, którą wydano w 1991 roku [91].

Tabela IV

Histologiczna klasyfikacja guzów gruczołów ślinowych (WHO, 1991) [91]

1. Gruczolak (adenoma)

2. Rak (carcinoma)

2.1 Rak zrazikowokomórkowy (acinic cell carcinoma)

2.2 Rak śluzowo-naskórkowy (mucoepidermoid carcinoma)

2.3 Rak gruczołowo-torbielowaty (adenoid cystic carcinoma)

2.4 Gruczolakorak polimorficzny o niskiej złośliwości (polymorphous low grade adenocarcinoma, terminal duct adenocarcinoma)

2.5 Rak nabłonkowo-mioepitelialny (epithelial-myoepithelial carcinoma)

2.6 Gruczolakorak podstawnokomórkowy (basal cell adenocarcinoma)

2.7 Rak łojowy (sebaceous carcinoma)

2.8 Torbielakogruczolakorak brodawkowaty (papillary cystadenoca.)

2.9 Gruczolakorak śluzowy (mucinous adenocarcinoma)

2.10 Gruczolakorak kwasochłonny (oncocytic carcinoma)

2.11 Rak przewodowy ślinianek (salivary duct carcinoma)

2.12 Gruczolakorak (adenocarcinoma)

2.13 Złośliwy mioepitelioma (myoepithelial carcinoma)

2.14 Rak w gruczolaku wielopostaciowym (ca. ex pleomorphic adenoma)

2.15 Rak płaskonabłonkowy (squamous cell carcinoma)

2.16 Rak drobnokomórkowy (small cell carcinoma)

2.17 Rak niezróżnicowany (undifferenciated carcinoma)

2.18 Inne raki (other carcinoma)

3. Nowotwory nienabłonkowe (non-epithelial tumours)

4. Chłoniaki złośliwe (malignant lymphomas)

5. Nowotwory wtórne (secondary tumours)

6. Nowotwory niesklasyfikowane (unclassified tumours)

7. Zmiany nowotworopodobne (tumour-like lesions) 
W porównaniu z pierwszą edycją uwzględniono m.in. nowe typy raków, celem bardziej precyzyjnego ich rozpoznawania, leczenia i przewidywania przebiegu klinicznego. W podgrupie raków wyodrębniono 18 ich typów, a więc łącznie z rakami (guzami według poprzedniej nomenklatury) śluzowo-naskórkowymi i zrazikowokomórkowymi, dodano do tej podgrupy 13 nowych rodzajów nabłonkowych nowotworów złośliwych [92]. Obowiązująca obecnie klasyfikacja histologiczna guzów gruczołów ślinowych została wydana w 2005 roku [5].

Tabela V

Złośliwe guzy nabłonkowe; Histologiczna klasyfikacja guzów gruczołów ślinowych (WHO, 2005) [5]

1. Rak zrazikowokomórkowy (acinic cell carcinoma)

2. Rak śluzowo-naskórkowy (mucoepidermoid carcinoma)

3. Rak gruczołowo-torbielowaty (adenoid cystic carcinoma)

4. Gruczolakorak polimorficzny o niskiej złośliwości (polymorphous low grade adenocarcinoma, terminal duct adenocarcinoma)

5. Rak jasnokomórkowy, bliżej nieokreślony (clear cell carcinoma, not other specified)

6. Rak nabłonkowo-mioepitelialny (epithelial-myoepithelial carcinoma)

7. Gruczolakorak podstawnokomórkowy (basal cell adenocarcinoma)

8. Rak łojowy (sebaceous carcinoma)

9. Gruczolakorak limfatyczny łojowy (sebaceous lymphadenocarcinoma),

10. Torbielakogruczolakorak (cystadenocarcinoma)

11. Torbielakogruczolakorak sitowaty o niskiej złośliwości (low grade cribriform cystadenocarcinoma)

12. Gruczolakorak śluzowy (mucinous adenocarcinoma)

13. Gruczolakorak kwasochłonny (oncocytic carcinoma)

14. Rak przewodowy ślinianek (salivary duct carcinoma)

15. Gruczolakorak, bliżej nieokreślony (adenocarcinoma, not other specified)

16. Złośliwy mioepitelioma (malignant myoepithelioma, myoepithelial carcinoma)

17. Rak w gruczolaku wielopostaciowym (carcinoma ex pleomorphic adenoma)

18. Mięsakorak (carcinosarcoma),

19. Przerzutujacy gruczolak wielopostaciowy (metastasizing pleomorphic adenoma)

20. Rak płaskonabłonkowy (squamous cell carcinoma)

21. Rak drobnokomórkowy (small cell carcinoma)

22. Rak olbrzymiokomórkowy (large cell carcinoma)

23. Lymphoepithelial carcinoma

24. Sialoblastoma 
Zawiera ona 24 rodzaje nabłonkowych nowotworów złośliwych. Oprócz wprowadzenia nowych, bardzo rzadkich typów raków (np. rak jasnokomórkowy), dodano dwa podtypy złośliwego guza mieszanego (mięsakorak i przerzutujący gruczolak wielopostaciowy), a także wyodrębniono raka olbrzymiokomórkowego i lymphoepithelial carcinoma (dotychczas sklasyfikowane jako raki niezróżnicowane) [5]. Mimo względnej rzadkości raków gruczołów ślinowych, w ewolucji klasyfikacji histologicznej WHO można zaobserwować tendencję do wyodrębniania nowych rodzajów nabłonkowych nowotworów złośliwych (7 w pierwszej edycji, 18 w drugiej, a w najnowszej, trzeciej edycji aż 24 ich rodzaje). Wprowadzanie nowych podtypów raków wiąże się z trudnościami w zakwalifikowaniu ich do wcześniej ustalonych grup, zarówno ze względu na cechy morfologiczne (histologiczne) jak i przebieg kliniczny. Należy również zwrócić uwagę, że mimo rozwoju technik immunohistochemicznych oraz cytofotometrii podstawą rozpoznania i klasyfikacji nowotworów gruczołów ślinowych są histologiczne cechy widziane w konwencjonalnym mikroskopie świetlnym [92].

Ze względu na obraz histologiczny i przebieg kliniczny nabłonkowe nowotwory złośliwe gruczołów ślinowych, można podzielić na guzy o niskim (low-grade), pośrednim (intermediate-grade) oraz wysokim (high-grade) stopniu złośliwości. Nowotwory o niskim stopniu złośliwości cechuje skłonność do naciekania okolicznych tkanek z tendencją do wznów miejscowych, zwłaszcza przy niepewnych lub dodatnich marginesach cięcia chirurgicznego, jednakże przerzuty odległe są rzadkie, a śmiertelność niska (5-20\%). Guzy o średnim stopniu złośliwości mają podobny przebieg kliniczny, jednakże niższe przeżycie 5-letnie (50-75\%). Wysoka złośliwość raków gruczołów ślinowych wiąże się z ich szybkim, naciekowo-guzowatym wzrostem, rozsiewem do regionalnych węzłów chłonnych, wczesnymi 
i częstymi przerzutami odległymi (przeżycie 5-letnie 5-45\%). Do raków o niskim stopniu złośliwości należą m.in.: rak zrazikowokomórkowy, rak śluzowonaskórkowy (o niskiej i pośredniej złośliwości), gruczolakorak polimorficzny o niskiej złośliwości, gruczolakorak podstawnokomórkowy, wysoko zróżnicowany gruczolakorak (bliżej nieokreślony), rak jasnokomórkowy, rak nabłonkowomioepitelialny, torbielakogruczolakorak. Rak gruczołowo-torbielowaty, rak łojowy, złośliwy mioepitelioma oraz lymphoepithelial carcinoma zaliczają się do nowotworów o pośrednim stopniu złośliwości. Najbardziej agresywne klinicznie (wysoki stopień złośliwości) to: nisko zróżnicowany rak śluzowo-naskórkowy, gruczolakorak (bliżej nieokreślony) o niskim stopniu zróżnicowania, rak płaskonabłonkowy, niezróżnicowane raki drobnokomórkowe i olbrzymiokomórkowe, rak w gruczolaku wielopostaciowym, rak przewodowy ślinianek, gruczolakorak kwasochłonny oraz odróżnicowane raki gruczołowo-torbielowaty i zrazikowokomórkowy [18].

Raki gruczołów ślinowych mogą rozwijać się de novo lub na podłożu istniejących nowotworów łagodnych. Najczęściej występujący nowotwór gruczołów ślinowych, gruczolak wielopostaciowy, może ulec przemianie złośliwej w raka w gruczolaku wielopostaciowym. Inne gruczolaki mogące ulec transformacji w nowotwór złośliwy to: gruczolak podstawnokomórkowy (rak w gruczolaku podstawnokomórkowym), mioepitelioma (myoepithelial carcinoma), gruczolak kwasochłonny (gruczolakorak kwasochłonny). Nowotwory złośliwe o małym stopniu złośliwości mogą ulegać progresji do większej złośliwości (np. rak śluzowo-naskórkowy, rak nabłonkowo-mioepitelialny), a także odróżnicowaniu z utratą wcześniejszych cech morfologicznych (np. rak zrazikowokomórkowy w gruczolakoraka o dużej złośliwości). Ponadto w przypadku niektórych raków (np. rak w gruczolaku wielopostaciowym nie naciekający poza pseudotorebkę „macierzystego” gruczolaka lub rak we- 
wnątrzprzewodowy nie naciekający podścieliska) używa się określenia „w miejscu” (in situ), dla odróżnienia od postaci inwazyjnej, naciekającej podścielisko lub przekraczającej torebkę gruczolaka [17].

\subsection{Omówienie cech histologicznych i klinicznych raków gruczołów ślinowych}

Rak zrazikowokomórkowy (acinic cell carcinoma) jest nowotworem posiadającym charakterystyczne surowiczo-groniaste zróżnicowanie komórek. Podobnie jak rak śluzowo-naskórkowy, był błędnie nazywany guzem zrazikowokomórkowym, obecnie został potwierdzony jego złośliwy charakter [91]. Rozwija się w każdym wieku (około 4\% chorych poniżej 20 roku życia), z niewielką przewagą kobiet. Lokalizuje się najczęściej w śliniance przyusznej (80\%) oraz w drobnych gruczołach ślinowych (17\%) [27]. Klinicznie manifestuje się jako wolno rosnący, ruchomy guz okolicy przyusznej, niekiedy ma charakter wieloguzkowy z naciekiem skóry, bólem (ok. 30\%) i niedowładem nerwu twarzowego (5-10\%). Czas trwania objawów nie przekracza zazwyczaj roku, ale zdarzają się przypadki wieloletnie [19, 27, 28]. Rak zrazikowokomórkowy może szerzyć się do regionalnych węzłów chłonnych i w konsekwencji dawać przerzuty odległe, najczęściej do płuc. Rokowanie zależy bardziej od zaawansowania klinicznego i stanu marginesów chirurgicznych niż od histologicznego stopnia złośliwości. 5-letnie przeżycie wynosi około 90\%, jednakże u 35\% chorych dochodzi do wznowy miejscowej, a $16 \%$ umiera z powodu tego nowotworu $[18,28,41]$.

Rak śluzowo-naskórkowy (mucoepidermoid carcinoma), zwany dawniej guzem Stewarda, jest jednym z najczęstszych nabłonkowych nowotworów złośliwych gruczołów ślinowych, zarówno u dzieci jak i dorosłych (średnia wieku 45 lat). 
W 53\% przypadków występuje w dużych gruczołach ślinowych, w większości w śliniance przyusznej [27, 41]. Zgodnie ze swoją nazwą zbudowany jest z komórek naskórkowych, pośrednich i śluzowych. Na podstawie kryteriów histologicznych, które dobrze korelują z przebiegiem klinicznym wyróżnia się jego trzy stopnie złośliwości - niską, pośrednią i wysoką. Klinicznie ujawnia się zazwyczaj jako twardy, słabo ruchomy i bezbolesny guz ślinianki, jednakże u około $1 / 3$ chorych występują dolegliwości bólowe i/lub parastezje, wycieki z ucha, niedowład lub porażenie nerwu twarzowego, owrzodzenie skóry, szczękościsk [32, 42, 70]. Rak śluzowonaskórkowy ślinianki przyusznej może szerzyć się do węzłów śródśliniankowych, podżuchwowych, jak również węzłów szyjnych poziomów III-V. Przerzuty odległe mogą pojawić się w płucach, wątrobie, kościach i mózgu. Rokowanie zależy ściśle od zaawansowania klinicznego, oraz od jego histologicznych cech złośliwości. W przypadku niskiej i pośredniej złośliwości jest dobre, poważne natomiast u chorych z rakiem o wysokim stopniu złośliwości (5-letnie przeżycie odpowiednio 92\%, $70-83 \%$ i $22-42 \%)[18,70]$.

Rak gruczołowo-torbielowaty (adenoid cystic carcinoma), dawniej zwany oblakiem (cylindroma), lokalizuje się najczęściej w śliniance przyusznej, podżuchwowej oraz drobnych gruczołach ślinowych podniebienia, jednakże może również rozwijać się w innych regionach głowy i szyi (zatoki przynosowe, gruczoł łzowy) [69, 102]. Występuje zazwyczaj miedzy 4 a 6 dekadą życia z niewielką przewagą u kobiet. Cechuje się zdolnością szerzenia się wzdłuż nerwów (inwazja około- i wewnątrznerwowa) daleko poza granicami guza pierwotnego, a także rozległym naciekaniem kości bez radiologicznych cech ich destrukcji. Najczęstszym objawem jest wolno rosnący guz przyusznicy, a następnie dolegliwości bólowe związane z naciekaniem okołonerwowym oraz porażenie nerwu twarzowego [69, 78, 102]. Czynniki 
wpływające na rokowanie to określone cechy utkania histologicznego, zaawansowanie kliniczne, naciekanie kości oraz stan marginesów chirurgicznych. Guzy mające utkanie cewkowe i sitowe są mniej agresywne niż te z przewagą struktur litych [78, 102, 107]. Chociaż przeżycie 5-letnie wynosi $60-75 \%$, to około $90 \%$ chorych umiera z powodu wznów miejscowych i przerzutów odległych w ciągu 10-15 lat. Wznowy miejscowe są bardzo częste, występują u 16-85\% leczonych. Zajęcie regionalnych węzłów chłonnych jest rzadkie, natomiast częstość przerzutów odległych (do płuc, kości, mózgu, wątroby) określa się na 25-55\% [18, 78].

Złośliwy guz mieszany (malignant mixed tumour) - termin ten odnosi się do trzech różnych nowotworów wywodzących się z łagodnego gruczolaka wielopostaciowego. Klasyfikacja WHO z 2005 r. wyodrębnia trzy typy złośliwego guza mieszanego jako: rak w gruczolaku wielopostaciowym (RwGW), mięsakorak oraz przerzutujacy gruczolak wielopostaciowy [5]. Ostatnie dwa typy pominięto ze względu na wyjątkową rzadkość występowania, są one przedmiotem doniesień wyłącznie kazuistycznych. Rak w gruczolaku wielopostaciowym (carcinoma ex pleomorphic adenoma) jest definiowany jako nabłonkowy nowotwór złośliwy rozwijający się w obrębie istniejącego wcześniej łagodnego gruczolaka wielopostaciowego (GW) lub w miejscu po jego usunięciu. Najczęściej ujawnia się w 6 i 7 dekadzie życia i rozwija się w śliniance przyusznej, chociaż może również lokalizować się w śliniance podżuchwowej i drobnych gruczołach ślinowych. Częstość przemiany złośliwej ocenia się na 2 - 23\% (średnio 6\%) wszystkich gruczolaków wielopostaciowych [37, 71]. Ryzyko zezłośliwienia wzrasta z czasem obecności guza łagodnego (od 2\% poniżej 5 lat do $9 \%$ ponad 15 lat) i jest związane z nagromadzeniem się niestabilności genetycznych w wieloletnim gruczolaku [18]. Średni czas przemiany złośliwej to 13 lat po pojawieniu się pierwotnego guza. Występowanie RwGW mie- 
ści się w zakresie 1-14\% (średnio 4\%) wszystkich guzów gruczołów ślinowych i około 12\% zmian złośliwych (od 3 do 42\%) [5]. Histologicznie proporcje między łagodną i złośliwą komponentą RwGW są zmienne, nierzadko pozostałości po istniejącym uprzednio gruczolaku wielopostaciowym są trudne lub wręcz niemożliwe do znalezienia. Dotyczy to również rozwoju RwGW w miejscu po uprzednio usuniętym, udokumentowanym histopatologicznie łagodnym GW. Najczęściej nabłonkowa komponenta złośliwa ma utkanie nisko zróżnicowanego gruczolakoraka lub raka niezróżnicowanego, jednakże inne typy raków (m.in. śluzowo-naskórkowy, gruczołowo-torbielowaty, płaskonabłonkowy) były również opisywane [18]. W rozwoju RwGW wyróżnia się trzy etapy. Pierwszy, najwcześniejszy to okres, w którym komponent złośliwy nie przekracza torebki macierzystego GW, a RwGW określany jest jako nieinwazyjny, w miejscu (in situ) lub wewnątrztorebkowy. Naciekanie tkanek poza torebką GW do $1,5 \mathrm{~mm}$ to etap minimalnej inwazji, a naciekanie powyżej 1,5 mm to postać inwazyjna [17]. RwGW manifestuje się klinicznie zazwyczaj szybkim powiększaniem istniejącego uprzednio guza (gruczolaka), jak również unieruchomieniem otaczających tkanek, bólem okolicy guza, niedowładem lub porażeniem nerwu twarzowego, naciekiem skóry czy powiększeniem regionalnych węzłów chłonnych. Wznowa miejscowa, jak i przerzuty odległe RwGW (zazwyczaj do płuc, kości, jamy brzusznej i mózgu) są częste. Ogniska przerzutowe tego nowotworu zbudowane są histologicznie wyłącznie z komponenty złośliwej. Rokowanie w przypadku RwGW zależy od utkania i zróżnicowania komponenty złośliwej, wielkości guza i stopnia naciekania poza torebkę macierzystego GW: dobre w fazie nieinwazyjnej oraz z minimalną inwazją, znacznie gorsze w postaci inwazyjnej z 5-letnim przeżyciem 25-65\% [5, 17, 18]. 
Gruczolakorak, bliżej nieokreślony (adenocarcinoma, not other specified) tym terminem określa się nowotwory złośliwe gruczołów ślinowych, wykazujące zróżnicowanie przewodowe bez innych cech morfologicznych umożliwiających bardziej precyzyjne ich sklasyfikowanie [5]. Gruczolakorak jest częstym (około 17\%) nowotworem dużych i małych gruczołów ślinowych (odpowiednio 60\% i 40\%), ze średnią wieku 58 lat [27]. Objawy gruczolakoraka ślinianki przyusznej są typowe dla nowotworów złośliwych, dość często (20\%) w jego przebiegu występuje niedowład lub porażenie nerwu twarzowego i ból [101]. Ze względu na brak cech patognomicznych tego nowotworu zawsze należy wykluczyć jego charakter przerzutowy. Rokowanie w przebiegu gruczolakoraka zależy od zaawansowania klinicznego i jego stopnia złośliwości $[18,101]$.

Rozpoznanie pierwotnego raka płaskonabłonkowego (epidermoid carcinoma, squamous cell carcinoma) gruczołów ślinowych jest możliwe wyłącznie po wykluczeniu jego przerzutowego charakteru i dotyczy tylko ślinianki przyusznej (80\%) i podżuchwowej (20\%) [5]. Nowotwór ma identyczną budowę z występującymi w błonie śluzowej górnych dróg oddechowych i pokarmowych [27]. Pierwotny rak płaskonabłonkowy dużych gruczołów ślinowych występuje rzadko, zazwyczaj między 6 a 8 dekadą życia, częściej u mężczyzn i zazwyczaj związany jest z przebytym napromienianiem okolicy głowy i szyi (15-30 lat wcześniej) [94]. Objawy takie jak twardy, nieprzesuwalny, szybko rosnący guz z lub bez towarzyszącego niedowładu nerwu twarzowego i powiększenia węzłów chłonnych szyi oraz dolegliwości bólowych, są podobne do występujących w przebiegu raków o innym utkaniu histologicznym $[94,105]$. Pierwotny rak płaskonabłonkowy ślinianki przyusznej jest agresywnym nowotworem o dużym stopniu złośliwości, z 5-letnim przeżyciem ocenia- 
nym na 25-30\%. Wznowy lokoregionalne występują u co najmniej połowy chorych, a przerzuty odległe u $20-30 \%[18,94]$.

Rak niezróżnicowany (undifferenciated carcinoma) gruczołów ślinowych zbudowany jest z prymitywnych lub anaplastycznych komórek, które w mikroskopie świetlnym nie wykazują żadnego zróżnicowania. Należy zawsze wykluczyć przerzuty tego nowotworu z innych narządów (płuca, tarczyca, skóra), a także konieczne jest jego różnicowanie przy użyciu technik immunohistochemicznych z nowotworami nienabłonkowymi (czerniak, chłoniak). Klasyfikacja WHO wyróżnia trzy podtypy tego nowotworu: rak drobnokomórkowy, rak olbrzymiokomórkowy oraz lymphoepithelial carcinoma [5]. Rak drobnokomórkowy (small cell carcinoma), zwany również owsianokomórkowym lub neuroendokrynnym, jest bardzo rzadkim nowotworem gruczołów ślinowych, zazwyczaj ślinianki przyusznej. Histologicznie stwierdza się jego trzy rodzaje (typu raka z komórek Merkela, typu płucnego i typu przewodowego) [18]. Rak drobnokomórkowy ma bardzo agresywny przebieg, u ponad 50\% chorych występują wznowa miejscowa i przerzuty odległe, zajęcie regionalnych węzłów chłonnych jest znacznie rzadsze. 5-letnie przeżycie wynosi 13 do 46\% [36, 68]. Jego przebieg kliniczny podobny jest do raka z komórek Merkela skóry, a rokowanie zdecydowanie lepsze niż w raku drobnokomórkowym płuca [18]. Rak olbrzymiokomórkowy (large cell carcinoma) również jest bardzo agresywnym nowotworem o wysokim stopniu złośliwości, z dużą skłonnością do nawrotów miejscowych, przerzutów odległych i do regionalnych węzłów chłonnych [68]. Lymphoepithelial carcinoma to nowotwór histologicznie i immunohistochemicznie identyczny z rozwijającym się w części nosowej gardła, a więc zawsze konieczne jest wykluczenie jego przerzutowego charakteru z tej okolicy [18]. Lymphoepithelial carcinoma cechuje się 
pośrednim stopniem złośliwości, dzięki leczeniu skojarzonemu uzyskuje się 5-letni okres przeżycia u 75-86\% pacjentów [53, 113].

Rak przewodowy ślinianek (salivary duct carcinoma) jest rzadkim, ale jednym z najbardziej agresywnych nowotworów złośliwych gruczołów ślinowych, w 80\% rozwijającym się w śliniance przyusznej. Występuje głównie miedzy 6 a 8 dekadą życia przeważnie u mężczyzn (ponad 4 razy częściej). Rak przewodowy charakteryzuje się częstym szerzeniem okołonerwowym (60\%), zatorami z komórek nowotworowych w naczyniach guza (31\%) i częstymi przerzutami do węzłów chłonnych (59\%) [6]. U 33\% pacjentów występuje wznowa miejscowa, a przerzuty odległe stwierdza się u 46\%, co potwierdza agresywny przebieg kliniczny tego nowotworu $[5,6,18]$.

Rak łojowy (sebaceous carcinoma) jest bardzo rzadkim nowotworem o pośrednim stopniu złośliwości, w 90\% rozwijającym się w obrębie ślinianki przyusznej. Występuje głównie w trzeciej oraz między 7 i 8 dekadą życia. Typowym objawem jest ból, porażenie nerwu twarzowego oraz unieruchomienie skóry nad guzem. 5-letnie przeżycie ocenia się na około $62 \%$ [5, 18, 26, 38].

Inne rzadkie typy gruczolakoraków takie jak gruczolakorak podstawnokomórkowy, gruczolakorak śluzowy, rak jasnokomórkowy, rak nabłonkowomioepitelialny, torbielakogruczolakorak oprócz specyficznych cech morfologicznych umożliwiających odrębne ich sklasyfikowanie, należą do nowotworów o niskim stopniu złośliwości ze stosunkowo łagodnym przebiegiem klinicznym i dobrym rokowaniem [5, 18]. 


\subsection{Zasady klasyfikacji klinicznej raków dużych gruczołów ślinowych}

Klasyfikacja TNM oparta jest na wielkości guza oraz jego umiejscowieniu w odniesieniu do określonych struktur anatomicznych. Wprowadza ona uszeregowanie nowotworów według rokowania, ułatwiając dobór leczenia i analizę porównawczą jego wyników [15]. Pierwsze próby klinicznego sklasyfikowania (TNM) nowotworów złośliwych dużych gruczołów ślinowych podejmowane były przez Amerykański Komitet Przeciwrakowy (AJCC) w 1983 roku i Japońskie Towarzystwo Przeciwrakowe (JJC) w 1984 roku. Miedzy innymi na ich podstawie w 1987 roku Międzynarodowa Unia Przeciwrakowa (UICC) zaprezentowała pierwszy międzynarodowy i powszechnie akceptowany system zaawansowania klinicznego nabłonkowych nowotworów złośliwych dużych gruczołów ślinowych (ślinianki przyusznej, podżuchwowej i podjęzykowej) [45, 72].

Na podstawie wielkości guza cechę T oceniano w 4-stopniowej skali, gdzie:

T1- guz nie przekracza $2 \mathrm{~cm}$ w największym wymiarze;

T2- guz powyżej $2 \mathrm{~cm}$, nie przekracza $4 \mathrm{~cm}$ w największym wymiarze;

T3- guz powyżej $4 \mathrm{~cm}$, nie przekracza $6 \mathrm{~cm}$ w największym wymiarze;

T4- guz przekracza $6 \mathrm{~cm}$ w największym wymiarze.

Dodatkowo wszystkie kategorie były podzielone na (a) - bez miejscowego naciekania oraz (b) - z miejscowym naciekaniem. Miejscowe naciekanie oznaczało makroskopowe cechy inwazji skóry, tkanek miękkich, kości lub nerwu twarzowego. Stwierdzenie nacieku tych struktur wyłącznie mikroskopowe nie stanowiło podstawy do sklasyfikowania jako miejscowe (pozagruczołowe) naciekanie .

Do oceny zaawansowania regionalnego wprowadzono 4-stopniową skalę wspólną dla wszystkich (z wyjątkiem tarczycy i części nosowej gardła) złośliwych nowotworów nabłonkowych głowy i szyi, gdzie: 
N0 - brak powiększonych węzłów chłonnych;

N1- przerzuty do pojedynczego ipsilateralnego węzła chłonnego, którego wielkość nie przekracza $3 \mathrm{~cm}$ w największym wymiarze;

$\mathrm{N} 2 \mathrm{a}$ - przerzut w pojedynczym ipsilateralnym węźle chłonnym większym niż 3, ale mniejszym niż $6 \mathrm{~cm}$;

$\mathrm{N} 2 \mathrm{~b}$ - przerzut do wielu ipsilateralnych węzłów chłonnych, największy z nich nie przekracza $6 \mathrm{~cm}$;

N2c - przerzuty w bilateralnych lub kontrlateralnych węzłach chłonnych, nie większych niż $6 \mathrm{~cm}$;

N3 - przerzuty w węźle chłonnym większym niż $6 \mathrm{~cm}$.

Dwustopniowa skala do oceny przerzutów odległych dużych gruczołów ślinowych jest identyczna z klasyfikacjami innych lokalizacji (Mx- brak możliwości oceny przerzutów odległych, M0- brak przerzutów odległych, M1- stwierdzone przerzuty odległe) [45].

Dopiero po 10 latach w 1997 r. Sobin zaprezentował pierwszą rewizję systemu TNM (5-ta edycja systemu TNM) raków dużych gruczołów ślinowych [95]. W oparciu o wyniki licznych badań wprowadzono szereg zmian do cechy T, klasyfikacja $\mathrm{N}$ i M pozostały niezmienione. Pozostawiono 4-stopniową skalę, ale zlikwidowano podział cechy $\mathrm{T}$ na dwie kategorie - bez miejscowego naciekania i z miejscowym naciekaniem. W nowym systemie przypadki bez naciekania miejscowego (zgodnie z wielkością guza) zostały sklasyfikowane jako T1 lub T2, natomiast te z niedowładem nerwu twarzowego, czynnikiem rokowniczo niekorzystnym, jako T4 $[15,72]$. Cechę $\mathrm{T}$ przedstawiano w 4-stopniowej skali, opartej na wielkości guza, cechach naciekania poza tkankę gruczołowa, nerwu twarzowego oraz podstawy czaszki: 
T1 - guz nie przekracza $2 \mathrm{~cm}$ w największym wymiarze, bez cech naciekania poza tkankę gruczołową;

T2 - guz powyżej $2 \mathrm{~cm}$, nie przekracza $4 \mathrm{~cm}$ w największym wymiarze, bez cech naciekania poza tkankę gruczołową;

T3 - guz powyżej $4 \mathrm{~cm}$, nie przekracza $6 \mathrm{~cm}$ i/lub wykazujący cechy kliniczne naciekania poza tkankę gruczołową;

T4 - guz naciekający podstawę czaszki, nerw twarzowy i/lub przekracza $6 \mathrm{~cm} \mathrm{w}$ największym wymiarze.

Kolejna, druga rewizja (6-sta edycja systemu TNM), została wprowadzona przez Sobina w 2002 r. i nie wnosi tak dużych zmian jak poprzednia, jest ona obowiązującą do dzisiaj [96]. Stopnie T1 i T2 pozostawiono niezmienione, w T3 usunięto górny zakres wielkości guza. Natomiast niezmiernie ważną zmianą jest podział cechy T4 na dwie kategorie T4a - guzy operacyjne i T4b- nieoperacyjne.

System TNM z 2002 roku ocenia zaawansowanie miejscowe następująco:

Tx - brak możliwości oceny guza;

T0 - $\quad$ nie ma guza pierwotnego;

Tis - $\quad$ rak in situ;

T1 - guz nie przekracza $2 \mathrm{~cm}$ w największym wymiarze, bez cech naciekania poza tkankę gruczołową;

T2 - guz powyżej $2 \mathrm{~cm}$, nie przekracza $4 \mathrm{~cm} \mathrm{w}$ największym wymiarze, bez cech naciekania poza tkankę gruczołową;

T3 - guz przekracza $4 \mathrm{~cm}$ i/lub wykazujący cechy kliniczne naciekania poza tkankę gruczołową;

T4a - guz naciekający skórę i/lub kość żuchwy i/lub przewód słuchowy zewnętrzny i/lub nerw twarzowy;

T4b - guz naciekający podstawę czaszki i/lub wyrostek skrzydłowy i/lub okalający tętnicę szyjną.

Cechy N i M pozostawiono niezmienione.

Zakwalifikowanie do poszczególnych stopni TNM opiera się na ocenie klinicznej 
(przed leczeniem) - cTNM oraz ocenie patologicznej (po leczeniu chirurgicznym) pTNM. Wszystkie klasyfikacje TNM nowotworów złośliwych dużych gruczołów ślinowych odnoszą się wyłącznie do raków.

Obowiązujący obecnie 4-stopniowy podział zaawansowania klinicznego nowotworów głowy i szyi (w tym dużych gruczołów ślinowych) oparty jest na klasyfikacji TNM z 2002 roku i przedstawia się następująco:

$\begin{array}{lccc}\text { Stopień 0 } & \text { Tis } & \text { N0 } & \text { M0 } \\ \text { Stopień I } & \text { T1 } & \text { N0 } & \text { M0 } \\ \text { Stopień II } & \text { T2 } & \text { N0 } & \text { M0 } \\ \text { Stopień III } & \text { T3 } & \text { N0 } & \text { M0 } \\ & \text { T1 } & \text { N1 } & \text { M0 } \\ & \text { T2 } & \text { N1 } & \text { M0 } \\ \text { Stopień IVA } & \text { T3 } & \text { N1 } & \text { M0 } \\ & \text { T4a } & \text { N0 } & \text { M0 } \\ & \text { T1-T4a } & \text { N2 } & \text { M0 } \\ \text { Stopień IVB } & \text { T4b } & \text { każde N } & \text { M0 } \\ & \text { każde T } & \text { N3 } & \text { M0 } \\ \text { Stopień IVC } & \text { każde T } & \text { każde N } & \text { M1 }\end{array}$

Na uwagę zasługuje podział IV stopnia zaawansowania klinicznego na 3 podtypy A, B i C. Stopień IVA oznacza zaawansowanie narządowe i regionalne umożliwiające leczenie operacyjne, IVB jest to zaawansowanie nieoperacyjne raka, przekraczające racjonalne wskazania do leczenia chirurgicznego, a do stopnia IVC klasyfikowani są chorzy z przerzutami odległymi [12]. 


\subsection{Metody i wytyczne dotyczące leczenia raków ślinianki przyusznej}

Podstawową metodą leczenia raków ślinianki przyusznej jest postępowanie chirurgiczne. Radioterapia ma zastosowanie jako leczenie uzupełniające, ewentualnie jako samodzielna metoda terapii w przypadku guzów nieoperacyjnych, u chorych z przeciwwskazaniami ogólnymi lub nie wyrażającymi zgody na zabieg operacyjny. Ponadto radioterapia i chemioterapia stosowane są w leczeniu paliatywnym [cyt. wg 12]. Wskazaniami do uzupełniającej radioterapii raków ślinianki przyusznej są: wysoki stopień złośliwości, wysokie zaawansowanie kliniczne, dodatnie lub niedostateczne marginesy cięcia chirurgicznego, nawrotowy charakter guza, przerzuty do regionalnych węzłów chłonnych [2, 99, 110].

Parotidektomia (wycięcie ślinianki przyusznej) jest jedyną uznawaną techniką chirurgiczną w leczeniu złośliwych nowotworów tego gruczołu. Parotidektomię można podzielić zgodnie z zakresem usuniętych tkanek na częściową i całkowitą. Częściowa polega na usunięciu powierzchownego płata ślinianki (część gruczołu bocznie w stosunku do nerwu twarzowego) i zwana jest również powierzchowną (boczną). Nie wykonuje się izolowanego usunięcia płata głębokiego (części gruczołu położonej przyśrodkowo od nerwu twarzowego). W całkowitej parotidektomii usuwa się cały miąższ ślinianki przyusznej (płat głęboki i powierzchowny). Ponadto używane jest również określenie parotidektomia rozszerzona, w której oprócz gruczołu usuwa się struktury sąsiadujące (np. skóra, mięśnie, fragment żuchwy, małżowiny usznej). Drugi podział parotidektomii związany jest z postępowaniem wobec nerwu twarzowego. Parotidektomia z usunięciem nerwu twarzowego nazywana jest radykalną, a z jego pozostawieniem - zachowawczą. Ponadto, w przypadku konieczności usunięcia części gałązek tego nerwu (np. gałęzi jarzmowej) używany jest termin pół- 
zachowawcza (ang. semi-conservative) [44]. Obecnie uważa się, że parotidektomię radykalną (z wycięciem nerwu twarzowego) należy wykonywać wyłącznie w przypadkach przedoperacyjnego porażenia lub stwierdzonego śródoperacyjnie naciekania nerwu. W sytuacji, gdy w badaniu przedoperacyjnym nie ma cech uszkodzenia nerwu twarzowego, a nerw można oddzielić od guza, to ryzyko wznowy raka związane z dodatnim marginesem mikroskopowym może zostać zminimalizowane przez uzupełniającą radioterapię [54, cyt. wg 82].

U większości chorych leczenie chirurgiczne guza pierwotnego (parotidektomia) łączy się z usunięciem regionalnych węzłów chłonnych szyi (operacje węzłowe). Obecnie obowiązuje podział i nazewnictwo operacji węzłowych szyi zaakceptowane przez Komitet Głowy, Szyi i Onkologii Amerykańskiej Akademii Otolaryngologii - Chirurgii Głowy i Szyi (AAO-HNS) oraz Komitet Naukowy Amerykańskiego Towarzystwa Chirurgii Głowy i Szyi (ASHNS) [22]. Operację węzłową szyi dzieli się ze względu na rozległość zabiegu na radykalną, radykalną zmodyfikowaną, selektywną oraz radykalną poszerzoną. W radykalnej operacji węzłowej usuwa się 5 grup (poziomy I-V węzłów chłonnych szyi) wraz mięśniem mostkowoobojczykowo-sutkowym, nerwem dodatkowym i żyłą szyjną wewnętrzną. W operacji radykalnej zmodyfikowanej usuwa się te same grupy węzłów chłonnych, ale zaoszczędza się co najmniej jedną z w/w struktur nielimfatycznych. Selektywna operacja węzłowa polega na usunięciu mniej niż pięć grup regionalnych węzłów chłonnych, na przykład I, II i III. W radykalnej poszerzonej operacji węzłowej usuwa się dodatkowe grupy węzłów chłonnych i/lub struktury nielimfatyczne [22].

W 2003 roku Bień [12] przedstawił standardy postępowania diagnostycznego i terapeutycznego w leczenia nowotworów gruczołów ślinowych (w tym raków ślinianki przyusznej), opracowane i dostosowane do polskich warunków na podsta- 
wie Programu SOR (standards, options, recommendations), który został utworzony przez Francuską Narodową Federację Ośrodków Onkologicznych (FNCLCC). Zaprezentowane standardy opierają się na zaawansowaniu klinicznym (TNM) oraz stopniu złośliwości raków ślinianki przyusznej. W I i II stopniu zaawansowania klinicznego (T1/2N0M0) nowotworów o niskim stopniu złośliwości zaleca się wykonanie parotidektomii powierzchownej $\mathrm{z}$ zaoszczędzeniem nerwu twarzowego lub jako opcję parotidektomię całkowitą zachowawczą. Wskazaniem do uzupełniającej radioterapii są dodatnie marginesy chirurgiczne, cechy naciekania pozagruczołowego lub okołonerwowego w badaniu patologicznym. W III stopniu zaawansowania klinicznego guzów o niskim stopniu złośliwości zalecenia różnią się w zależności od cechy N. W przypadku braku powiększonych klinicznie węzłów chłonnych szyi (T3N0M0) zaleca się parotidektomię całkowitą z możliwością zachowania ciągłości nerwu twarzowego lub jego gałęzi wraz z selektywną operacją węzłową (poziomy I-III węzłów chłonnych szyi). Wskazaniem do uzupełniającej radioterapii są dodatnie marginesy cięcia chirurgicznego, mikroprzerzuty bądź cechy naciekania pozagruczołowego lub okołonerwowego w badaniu patologicznym. W T1-3N1M0 rekomenduje się wykonanie parotidektomii zachowawczej powierzchownej lub całkowitej $\mathrm{z}$ operacją radykalną węzłów chłonnych szyi oraz uzupełniającą radioterapią w każdym przypadku. W przypadku nowotworów o wysokim stopniu złośliwości w I i II stopniu zaawansowania klinicznego zaleca się parotidektomię całkowitą z zachowaniem ciągłości nerwu twarzowego (ewentualnie poświęcenia całości lub jego części jeżeli wymaga tego radykalność zabiegu) z selektywną operacją węzłową szyi (poziomy I-III) oraz uzupełniającą radioterapią. Jako opcję terapeutyczną podaje się wykonanie selektywnej operacji węzłowej tylko w przypadku śródoperacyjnego stwierdzenia powiększonych węzłów chłonnych, a radioterapię uzupełniającą tylko w przypadku 
braku marginesów cięcia chirurgicznego, bądź cech naciekania pozagruczołowego lub okołonerwowego w badaniu patologicznym. W III stopniu zaawansowania klinicznego raków o dużym stopniu złośliwości zalecenia różnią się w zależności od cechy N. W 3 stopniu zaawansowania narządowego, bez powiększonych węzłów chłonnych (T3N0M0) rekomenduje się parotidektomię całkowitą radykalną, ewentualnie rozszerzoną o sąsiadujące struktury oraz w każdym przypadku selektywną operacje węzłową szyi (poziomy I-III). Wskazania do uzupełniającej radioterapii są identyczne, jak w przypadku guzów o niskim stopniu złośliwości (dodatnie marginesy cięcia chirurgicznego, mikroprzerzuty bądź cechy naciekania pozagruczołowego lub okołonerwowego w badaniu patologicznym). W zaawansowaniu narządowym T1-3 i regionalnym N1 nowotworów o wysokim stopniu złośliwości zaleca się parotidektomię całkowitą radykalną lub półzachowawczą z radykalną operacją węzłową szyi i uzupełniającą radioterapią w każdym przypadku. W IV stopniu zaawansowania klinicznego dla nowotworów o niskim i wysokim stopniu złośliwości nie ma szczegółowych zaleceń leczenia chirurgicznego. Jako opcję terapeutyczną (indywidualną w każdym przypadku) uznaje się wycięcie guza pierwotnego w granicach tkanek zdrowych z radykalną operacją węzłową szyi i uzupełniającą radioterapią [12].

W innych polskich zaleceniach postępowania w przypadku guzów gruczołów ślinowych z 2006 roku nie występuje podział na nowotwory o dużym i niskim stopniu złośliwości. Według tych rekomendacji, przy decyzji o sposobie leczenia (parotidektomia częściowa lub całkowita, z lub bez operacji węzłowej szyi i/lub uzupełniającej radioterapii) powinno się brać pod uwagę wielkość guza (do i powyżej $4 \mathrm{~cm}$, dla raka gruczołowo-torbielowatego powyżej $2 \mathrm{~cm}$ ), cechy kliniczne wskazujące na złośliwość (szybki wzrost, unieruchomienie/naciekania tkanek sąsiadujących, ból, niedowład/porażenie nerwu twarzowego), lokalizację (płat powierzchowny, głę- 
boki), stan węzłów chłonnych i inne histologiczne czynniki ryzyka (pośredni stopień złośliwości raka gruczołowo-torbielowatego, naciek nerwu lub perineurium, szerzenie się wzdłuż naczyń krwionośnych/chłonnych, stan marginesów operacyjnych). Zwraca uwagę brak rekomendacji wykonywania elektywnej operacji węzłowej w przypadku cechy N0, natomiast w N+ zaleca się zarówno operację węzłową radykalną, jak i selektywną [118]. 


\section{CEL PRACY}

1. Analiza danych kliniczno-patologicznych chorych $\mathrm{z}$ pierwotnym rakiem ślinianki przyusznej.

2. Ocena odległych wyników leczenia z uwzględnieniem danych klinicznych i patologicznych.

3. Ocena czynników wpływających na wyniki leczenia. 


\section{MATERIAŁ I METODA}

Materiał stanowi 131 chorych leczonych w latach 1978 - 2008 w Klinice Chorób Uszu, Nosa, Gardła i Krtani Gdańskiego Uniwersytetu Medycznego z powodu pierwotnego raka ślinianki przyusznej. Analizą kliniczno-patologiczną objęto wszystkich chorych, natomiast odległe wyniki leczenia opracowano na podstawie danych uzyskanych od 109 chorych, po wyłączeniu 12, którzy żyją a czas ich obserwacji był mniejszy niż 5 lat oraz 10 pacjentów, których dalszych losów nie zdołano ustalić.

Dane dotyczące chorych oraz przebiegu leczenia uzyskano na podstawie dokumentacji lekarskiej (historie choroby, protokoły operacyjne), a dalsze ich losy ustalono w oparciu o dokumentację z badań kontrolnych przeprowadzonych w Poradni Otolaryngologicznej Przychodni Przyklinicznej Uniwersyteckiego Centrum Klinicznego lub Wojewódzkim Centrum Onkologii w Gdańsku, informacji listownych i telefonicznych uzyskanych od chorych lub ich rodzin.

Ocenę zaawansowania nowotworów złośliwych ślinianki przyusznej oraz ostateczne rozpoznanie ustalono na podstawie badania klinicznego, badań dodatkowych (sialografii, ultrasonografii ślinianek i szyi, tomografii komputerowej i tomografii metodą rezonansu magnetycznego) przeprowadzonych głównie w Zakładzie Rentgenodiagnostyki Gdańskiego UM (kierownik: prof. dr hab. med. Michał Studniarek) oraz badania histologicznego materiału operacyjnego, które wykonano w Zakładzie Patomorfologii Gdańskiego UM (kierownik: prof. dr hab. med. Wojciech Biernat, uprzednio prof. dr hab. med. Kazimierz Jaśkiewicz).

Podział kliniczny raków ślinianki przyusznej oparto na klasyfikacji TNM Międzynarodowej Unii Przeciwrakowej (UICC) z 2002 roku, histologiczny - według 
klasyfikacji Światowej Organizacji Zdrowia (WHO) z 2005 roku (po reklasyfikacji danych chorych).

Podział operacji ślinianki przyusznej (parotidektomii) podano zgodnie z nomenklaturą występującą w światowym piśmiennictwie [44], zaś nazewnictwo operacji węzłowych zgodnie z wspólną propozycją Amerykańskiej Akademii Otolaryngologii - Chirurgii Głowy i Szyi oraz Amerykańskiego Towarzystwa Chirurgii Głowy i Szyi (2008 rok).

Chorych poddawanych radioterapii leczono w Klinice Onkologii i Radioterapii Gdańskiego Uniwersytetu Medycznego (kierownik: prof. dr hab. med. Jacek Jassem) lub Zakładzie Radioterapii Gdyńskiego Centrum Onkologii (dyrektor lek. Irena Erecińska-Siwy).

Z uzyskanych informacji utworzono komputerową bazę danych (program Microsoft Office Access 2003), a następnie przedstawiono w tabelach oraz na rycinach i poddano analizie statystycznej przy użyciu oprogramowania komputerowego Statistica 8.0 firmy StatSoft, Inc. licencjonowanego dla Gdańskiego Uniwersystetu Medycznego. Zgodność badanych zmiennych z rozkładem normalnym oceniano testem Kołmogorowa-Smirnowa. Porównania pomiędzy zmiennymi o charakterze normalnym oceniano przy pomocy testu t-Studenta. Do porównywania zmiennych o rozkładzie znacznie odbiegającym od normalnego wykorzystywano nieparametryczny test U Manna-Whitneya. Korelacje pomiędzy zmiennymi o rozkładzie normalnym badano metodą Pearsona, w przeciwnym przypadku metodą korelacji rang Spearmanna. Związki pomiędzy zmiennymi o charakterze jakościowym badano testem chi kwadrat Pearsona. W przypadku oceny czynników rokowniczych za miarę siły efektu wybrano iloraz szans (OR, ang. odds ratio). Prawdopodobieństwo przeżycia oceniano metodą Kaplana-Meiera. Do porównania prawdopodobieństwa przeży- 
cia pomiędzy dwiema grupami pacjentów użyto testu Wilcoxona według Gehana. Do przeprowadzenia analizy wieloczynnikowej przeżycia wykorzystano regresję proporcjonalnego hazardu Coxa. Za poziom istotności statystycznej w pracy przyjęto $\mathrm{p}<0,05$. 


\section{WYNIKI}

\subsection{Dane kliniczno-patologiczne}

W analizowanej grupie 131 chorych było 70 kobiet $(53,4 \%)$ oraz 61 mężczyzn (46,6\%), stosunek kobiet do mężczyzna wynosił 1,1:1. Wiek chorych wahał się od 11 do 90 lat. Średnia wieku wynosiła 58 lat, kobiet 57, mężczyzn 59 lat. Zarówno w grupie kobiet jak i mężczyzn dominowali chorzy w wieku 51 do 80 lat (60,0\% kobiet i 69,0\% mężczyzn, ze szczytem zachorowań kolejno w 7 i 6 dekadzie życia). Młodzi chorzy poniżej 20 roku życia stanowili jedynie 2,3\%. Wiek chorych z uwzględnieniem płci przedstawia rycina 1.

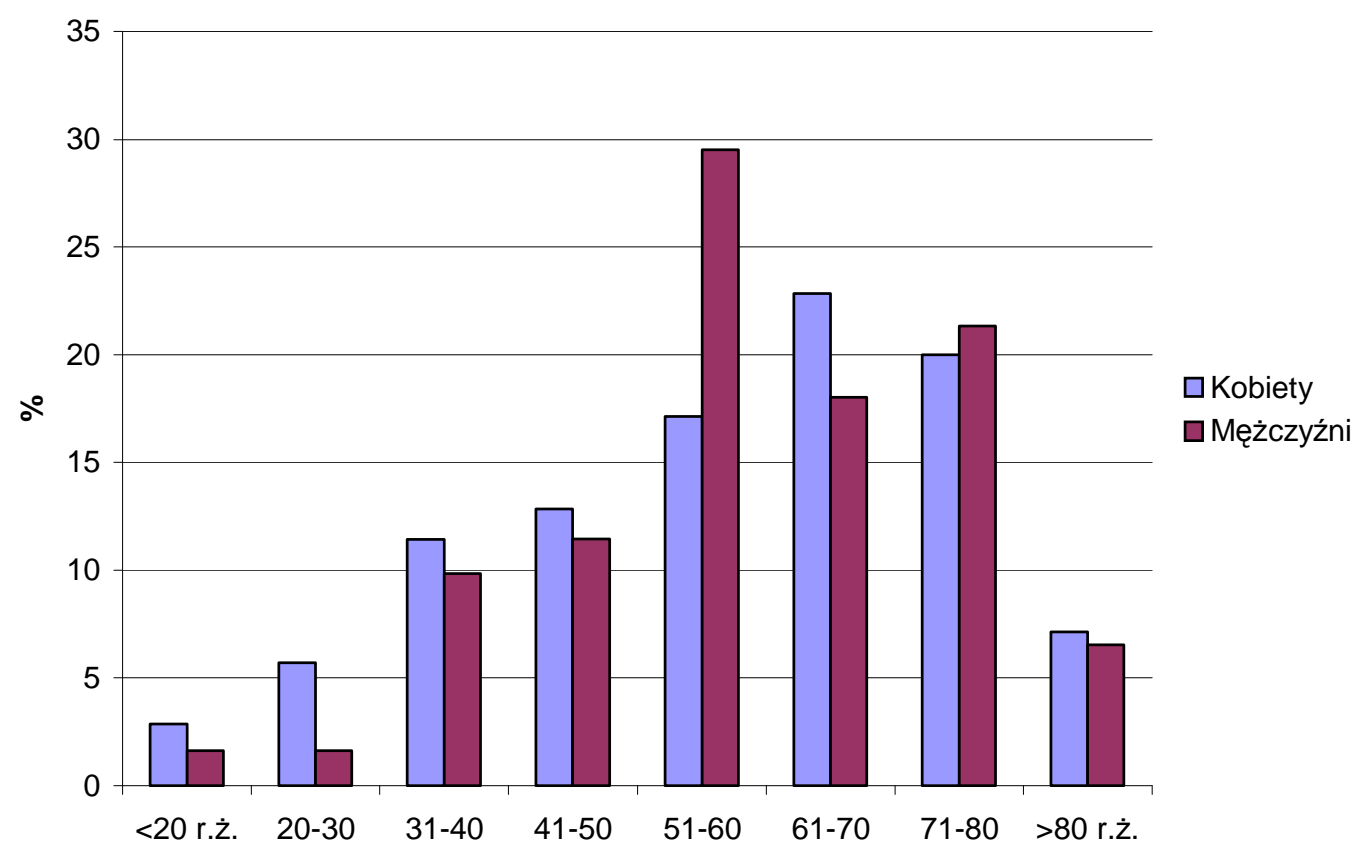

Ryc. 1. Wiek chorych z uwzględnieniem płci

Objawy zgłaszane przez chorych i odchylenia w badaniu klinicznym zostały zebrane łącznie i przedstawione w tabeli VI. 
Tabela VI.

Objawy i odchylenia w badaniu klinicznym

\begin{tabular}{lcc}
\hline Objawy i odchylenia w badaniu klinicznym & $\mathrm{n}$ & $\%$ \\
\hline Guz ślinianki przyusznej & 127 & 96,9 \\
Ból & 53 & 40,4 \\
Powiększone węzły chłonne szyi & 42 & 32,0 \\
Uszkodzenie nerwu VII & 27 & 20,6 \\
Naciek, unieruchomienie, owrzodzenie skóry & 26 & 19,8 \\
Parastezje & 13 & 9,9 \\
Inne Szczękościsk & 5 & 3,8 \\
$\quad$ Asymetria gardła & 4 & 3,0 \\
$\quad$ Guz policzka & 3 & 2,3 \\
$\quad$ Krwawienie z przewodu wyprowadzającego ślinianki & 2 & 1,5 \\
$\quad$ Nacieczenie ujścia przewodu wyprowadzającego ślinianki & 2 & 1,5 \\
$\quad$ Porażenie nerwu IX & 2 & 1,5 \\
\hline
\end{tabular}

Obecność guza ślinianki przyusznej stwierdzono u 127 chorych $(96,9 \%)$. U 8 z nich guz miał charakter wieloogniskowy, u 3 pojawił się w miejscu po uprzednio usuniętym gruczolaku wielopostaciowym, a u kolejnych 3 guz miał postać nacieku. Szybkie powiększanie się guza podawało 61 chorych (46,5\%). Unieruchomienie guza względem podłoża stwierdzono u 44 pacjentów (33,6\%). Ból był drugim pod względem częstości objawem i występował u 53 pacjentów (40,4\%). U 50 z nich $(38,2 \%)$ dotyczył okolicy guza i twarzy, natomiast u 10 (7,6\%) manifestował się jako otalgia. Powiększone węzły chłonne szyi obserwowano w 42 przypadkach (32,0\%). Kolejnym częstym objawem było zaburzenie czynności nerwu twarzowego, które występowało u 27 chorych (20,6\%). U 23 (17,5\%) dotyczyło wszystkich gałęzi nerwu. U 10 pacjentów $(7,6 \%)$ uszkodzenie nerwu miało charakter całkowitego porażenia. Naciek skóry występował u 26 chorych (19,8\%), z czego jej owrzodzenie stwierdzo- 
no u $8 \mathrm{z}$ nich $(6,1 \%)$. Zaburzenia czucia pod postacią parastezji podawało 13 chorych $(9,9 \%)$. Rzadsze objawy i odchylenia w badaniu to szczękościsk (5 chorych), nacieczenie ujścia lub krwawienie z przewodu wyprowadzającego ślinianki (po 2 chorych) oraz objawy porażenia nerwu językowo-gardłowego (2 przypadki). Asymetria gardła (przyśrodkowe przemieszczenie migdałka podniebiennego) stwierdzono u 4 chorych, przy czym u 1 z nich nie był wyczuwalny guz ślinianki przyusznej. Guz policzka stwierdzono u 3 chorych.

Odsetek poszczególnych objawów i odchyleń w badaniu był zróżnicowany w zależności od stopnia złośliwości raków. W grupie chorych z rakami o wysokim stopniu złośliwości w porównaniu z pacjentami z nowotworami o pośredniej lub niskiej złośliwości częściej występował ból (47,1\% vs 26,1\%), upośledzenie funkcji nerwu twarzowego (28,0\% vs 4,7\%), powiększenie węzłów chłonnych (34,8\% vs $26,1 \%)$, a także zajęcie skóry $(21,3 \%$ vs $16,6 \%$, w tym owrzodzenie - 7,8\% vs $2,3 \%$ ), jak również parastezje okolicy guza i/lub policzka - 14,2\% vs $7,8 \%$ chorych.

Wśród wszystkich objawów i odchyleń w badaniu klinicznym wyróżniono te, które wskazywały na złośliwy charakter nowotworu ślinianki (objawy złośliwości). Do objawów tych należały zaburzenie czynności nerwu twarzowego, nacieczenie lub owrzodzenie skóry, ból, powiększenie węzłów chłonnych szyi, szybki wzrost guza, szczękościsk, porażenie nerwu językowo-gardłowego, krwawienie z przewodu wyprowadzającego ślinianki. Tabela VII przedstawia podział chorych w zależności od liczby objawów złośliwości. 
Tabela VII

Podział chorych w zależności od liczby objawów złośliwości

\begin{tabular}{lcccccc}
\hline $\begin{array}{l}\text { Liczba objawów } \\
\text { złośliwości }\end{array}$ & \multicolumn{2}{c}{$\begin{array}{c}\text { Całość } \\
(\mathrm{n}=131)\end{array}$} & \multicolumn{2}{c}{$\begin{array}{c}\text { WSZ } \\
(\mathrm{n}=89)\end{array}$} & \multicolumn{2}{c}{$\begin{array}{c}\text { P/NSZ } \\
(\mathrm{n}=42)\end{array}$} \\
\hline 0 & $\mathrm{n}$ & $\%$ & $\mathrm{n}$ & $\%$ & $\mathrm{n}$ & $\%$ \\
\hline 1 & 27 & 20,6 & 16 & 18,0 & 11 & 26,2 \\
2 & 34 & 25,9 & 17 & 19,1 & 17 & 40,5 \\
3 & 30 & 22,9 & 24 & 27,0 & 6 & 14,3 \\
4 & 17 & 13,0 & 13 & 14,6 & 4 & 9,5 \\
5 & 15 & 11,4 & 13 & 14,6 & 2 & 4,8 \\
6 & 7 & 5,3 & 5 & 5,6 & 2 & 4,8 \\
\hline
\end{tabular}

Objawy złośliwości: naciek skóry, ból, niedowład/porażenie nerwu VII, powiększone węzły chłonne szyi, szybki wzrost guza, inne (szczękościsk, porażenie nerwu IX, naciek przewodu wyprowadzającego, krwawienie z przewodu wyprowadzającego) WSZ - wysoki stopień złośliwości; P/NSZ - pośredni/niski stopień złośliwości

W analizowanej grupie, 27 chorych (20,6\%) nie prezentowało żadnego, a kolejnych 34 (25,9\%) miało wyłącznie jeden objaw złośliwości. W 40 przypadkach (30,5\%) stwierdzono co najmniej 3 objawy wskazujące na proces złośliwy. W przedstawionym zestawieniu widoczne są różnice między nowotworami o wysokim a pośrednim i niskim stopniu złośliwości. U 28 chorych $(66,7 \%)$ z rakami o niskim i pośrednim oraz u $33(37,1 \%)$ z rakami o wysokim stopniu złośliwości nie stwierdzono żadnego lub maksymalnie jeden objaw złośliwości. 32 chorych $(35,9 \%)$ z rakiem o wysokim stopniu złośliwości i 8 pacjentów $(19,0 \%)$ z rakami o niskim stopniu złośliwości miało co najmniej trzy objawy wskazujący na proces złośliwy.

W całym materiale średnia liczba objawów złośliwości wynosiła 1,8 (w grupie raków o wysokim stopniu złośliwości 2,1, a w grupie o niskim i pośrednim stopniu złośliwości 1,4). Średni czas trwania objawów przed zgłoszeniem się chorego do lekarza wynosił 51,3 miesięcy, a w przypadku objawów sugerujących proces zło- 
śliwy - 4 miesiące. Po wyłączeniu grupy chorych z rakiem w gruczolaku wielopostaciowym średni czas trwania objawów wynosił 25,4 miesiące .

W grupie raków o wysokim stopniu złośliwości średni czas trwania objawów wynosił 60,9 miesięcy i był blisko dwukrotnie dłuższy niż w rakach o niskim/pośrednim stopniu złośliwości (31 miesięcy), jednakże po wyłączeniu przypadków raka w gruczolaku wielopostaciowym był zdecydowanie krótszy (21,8 miesięcy). Nie obserwowano istotnych różnic w średnim czasie trwania objawów złośliwości między grupami chorych z rakami o wysokim i pośrednim/niskim stopniem złośliwości. Tabela VIII przedstawia średni czas trwania objawów z uwzględnieniem chorych z rakiem w gruczolaku wielopostaciowym oraz stopnia złośliwości raka.

Tabela VIII.

Średni czas trwania objawów

\begin{tabular}{lcccc}
\hline & $\begin{array}{c}\text { Średni czas trwania wszystkich } \\
\text { objawów (miesiące) }\end{array}$ & $\begin{array}{c}\text { Średni czas trwania } \\
\text { objawów złośliwości } \\
\text { (miesiące) }\end{array}$ \\
\hline Całość & 51,3 & 25,4 & 139,7 & 4 \\
Wysoki SZ & 60,9 & 21,8 & - & 3,9 \\
Pośredni/Niski SZ & 31 & 31 & - & 4 \\
\hline \multicolumn{2}{c}{$\begin{array}{l}\text { RwGW- Rak w gruczolaku wielopostaciowym } \\
\text { SZ - stopień złośliwości }\end{array}$} &
\end{tabular}

Charakter i rozległość guzów ślinianki przyusznej oceniano przy użyciu dostępnych technik obrazowania, zgodnie $\mathrm{z}$ ich rozwojem w ciagu ostatnich 30 lat. Diagnostyka obrazowa oparta była początkowo wyłącznie na metodzie kontrastowego badania przewodów gruczołowych i miąższu ślinianki (sialografii), od 1985 roku wykonywano ultrasonografię (USG), natomiast diagnostyka metodą tomografii komputerowej (TK) była dostępna od 1990 roku, a tomografii rezonansu magnetycznego (MR) od 1998 roku. Spośród 19 chorych, u których wykonano sialografię, tylko 
u jednego z nich wykazała ona cechy złośliwości guza (przerwanie ciągłości przewodów ślinianki). Badanie USG w analizowanej grupie 131 chorych wykonano u 81 (61,8\%), dzięki niemu uzyskano dane dotyczące wielkości guza, jego charakteru (lity/torbielowato-lity, pojedynczy/ wieloogniskowy), struktury wewnętrznej, ograniczenia (obecność torebki) oraz stanu regionalnych węzłów chłonnych. Cechy złośliwości w USG, takie jak nieregularne zarysy guza, naciekanie poza miąższ ślinianki, obecność regionalnych węzłów chłonnych o charakterze przerzutowym, stwierdzono w 38 (46,9\%) przypadkach. Nowoczesne metody obrazowania TK i MR wykonano odpowiednio u $29(22,1 \%)$ i $9(6,9 \%)$ chorych. Umożliwiały one bardziej precyzyjną ocenę rozległości procesu nowotworowego i potwierdzenie jego złośliwego charakteru, m.in. zajęcie przestrzeni przygardłowej, naciekanie tkanek miękkich oraz kości. Radiologiczne cechy złośliwości guzów ślinianki przyusznej stwierdzono w $23(79,3 \%)$ badaniach TK oraz w 7 na 9 badań metodą MR.

Przedoperacyjną diagnostykę $\mathrm{w}$ postaci biopsji aspiracyjnej cienkoigłowej (BAC) wykonano u 89 spośród 131 chorych $(67,9 \%)$. Na podstawie BAC rozpoznano złośliwy charakter nowotworu (wynik prawdziwie dodatni) u 50 chorych $(56,2 \%)$, natomiast brak nowotworu lub nowotwór łagodny (wynik fałszywie ujemny) u 35 pacjentów (39,3\%). W 4 przypadkach (4,5\%) BAC była niediagnostyczna. Pełną zgodność rozpoznania cytologicznego z histopatologicznym uzyskano w 13 przypadkach $(14,6 \%)$. Wśród wyników fałszywie ujemnych najczęściej rozpoznawano w BAC nowotwór łagodny (gruczolak) - 22 chorych (24,7\%), następnie brak nowotworu, zmianę zapalną (sialadenitis) i torbiel, odpowiednio u 8, 3 i 2 pacjentów $(9,0 \%, 3,4 \%, 2,2 \%)$.

Śródoperacyjne badanie histologiczne wykonano u 66 spośród 131 chorych (50,4\%). Złośliwy charakter nowotworu stwierdzono u 56 (84,8\%). Pełna zgodność 
$\mathrm{z}$ ostatecznym rozpoznaniem histopatologicznym w trybie zwykłym miała miejsce u 20 pacjentów (30,3\%). Rozpoznanie nabłonkowego nowotworu złośliwego postawiono u 30 chorych $(45,4 \%)$, natomiast u kolejnych $6(9,1 \%)$ podano błędnie jego utkanie (podtyp). Brak cech złośliwości guza, a więc wynik fałszywie ujemny stwierdzono w 10 przypadkach $(15,1 \%)$, w tym nowotwór łagodny u 8, a u 2 chorych badanie śródoperacyjne nie wykazało w ogóle żadnego nowotworu.

W analizowanym materiale dominował drugi (T2) i czwarty (T4) stopień zaawansowania narządowego - odpowiednio 43 (32,8\%) i 54 chorych (41,2\%). Stopień T1 miało 12 chorych $(9,2 \%)$, a T3 - $22(16,8 \%)$. U 89 chorych $(67,9 \%)$ nie stwierdzono powiększonych węzłów chłonnych (N0). Stopień N1 i N2 określono odpowiednio u $22(16,8 \%)$ i 20 pacjentów (15,3\%), trzeci stopień zaawansowania regionalnego nie występował. 10 chorych bez powiększonych węzłów chłonnych było w stopniu T1, 37 w T2, a 12 w T3. W stopniu T4 również dominowali chorzy bez klinicznie powiększonych węzłów chłonnych - 30, kolejnych 11 miało stopień N1, a 13 - N2. Tabela IX przedstawia zaawansowanie narządowe i regionalne.

Tabela IX.

Zaawansowanie narządowe i regionalne

\begin{tabular}{|c|c|c|c|c|c|c|}
\hline & \multirow[t]{2}{*}{ No } & \multirow[t]{2}{*}{ N1 } & \multirow[t]{2}{*}{$\mathrm{N} 2$} & \multirow[t]{2}{*}{$\mathrm{N} 3$} & \multicolumn{2}{|c|}{ Razem } \\
\hline & & & & & $\mathrm{n}$ & $\%$ \\
\hline $\mathrm{T} 1$ & 10 & 2 & - & - & 12 & 9,2 \\
\hline $\mathrm{T} 2$ & 37 & 5 & 1 & - & 43 & 32,8 \\
\hline $\mathrm{T} 3$ & 12 & 4 & 6 & - & 22 & 16,8 \\
\hline $\mathrm{T} 4 *$ & 30 & 11 & 13 & - & 54 & 41,2 \\
\hline Łącznie & 89 & 22 & 20 & - & 131 & \\
\hline$\%$ & 67,9 & 16,8 & 15,3 & & & 100 \\
\hline
\end{tabular}

*łącznie T4a (51) i T4b (3) 
62 chorych $(47,3 \%)$ miało IV stopień zaawansowania klinicznego. II i III stopień miało odpowiednio $37(28,2 \%)$ i 22 pacjentów (16,8\%), natomiast pierwszy stopień tylko 10 chorych (7,6\%). Wysoki (III i IV) stopień zaawansowania klinicznego stwierdzono łącznie u 84 chorych $(64,1 \%)$.

Drugi nowotwór złośliwy (drugie pierwotne ognisko nowotworowe) występował u 18 spośród 109 chorych $(16,5 \%)$ podczas co najmniej 5 letniego okresu obserwacji. W 4 przypadkach miał charakter synchroniczny. Zdecydowanie dominowały raki skóry głowy (m.in. nos, małżowina uszna) o utkaniu podstawnokomórkowym lub płaskonabłonkowym - łącznie 10 chorych. Dwaj pacjenci zmarli z powodu drugiego nowotworu, w tym chory, u którego dwa niezależne ogniska gruczolakoraka (jelita grubego i gruczołu krokowego) rozwinęły się po 20 i 26 latach od leczeniu raka ślinianki przyusznej. Tabela X przedstawia drugie pierwotne nowotwory złośliwe z uwzględnieniem budowy histologicznej nowotworu ślinianki oraz lokalizacji, budowy histologicznej i czasu wystąpienia drugiego nowotworu. 
Tabela X

Drugie pierwotne nowotwory złośliwe u chorych leczonych z powodu raka ślinianki przyusznej

\begin{tabular}{|c|c|c|c|c|}
\hline $\begin{array}{l}\text { Płeć, } \\
\text { wiek }\end{array}$ & $\begin{array}{l}\text { Budowa histologiczna } \\
\text { nowotworu ślinianki }\end{array}$ & $\begin{array}{l}\text { Lokalizacja dru- } \\
\text { giego nowotworu }\end{array}$ & $\begin{array}{l}\text { Budowa histologiczna drugiego } \\
\text { nowotworu }\end{array}$ & $\begin{array}{l}\text { Charakter i czas } \\
\text { występowania } * *\end{array}$ \\
\hline $\mathrm{K}, 60$ & RwGW* & Nerka & Rak jasnokomórkowy & Meta $(-10)$ \\
\hline M, 56 & Rak śluzowo-naskórkowy & Płuco & Gruczolakorak & Syn (0) \\
\hline K, 68 & Rak gruczołowo-torbielowaty & Płuco & Rak płaskonabłonkowy & Meta $(+24)$ \\
\hline M, 57 & Rak gruczołowo-torbielowaty & Płuco & Gruczolakorak & Syn $(0)$ \\
\hline M, 56 & Rak gruczołowo-torbielowaty & Gruczoł krokowy & Gruczolakorak & Meta $(+170)$ \\
\hline M, 58 & Rak gruczołowo-torbielowaty & $\begin{array}{l}\text { Gruczoł krokowy } \\
\text { Jelito grube }\end{array}$ & $\begin{array}{l}\text { Gruczolakorak } \\
\text { Gruczolakorak }\end{array}$ & $\begin{array}{l}\text { Meta }(+240) \\
\operatorname{Meta}(+312)+\end{array}$ \\
\hline K, 72 & Rak śluzowo-naskórkowy & Skóra (głowa) & Rak podstawnokomórkowy & Meta $(-7)$ \\
\hline $\mathrm{K}, 43$ & Gruczolakorak BNO & Skóra (głowa) & Rak podstawnokomórkowy & Meta $(-36)$ \\
\hline M, 50 & Gruczolakorak BNO & Skóra (głowa) & Rak podstawnokomórkowy & $\operatorname{Meta}(+270)$ \\
\hline $\mathrm{K}, 87$ & Rak płaskonabłonkowy & Skóra (głowa) & Rak podstawnokomórkowy & Syn (-4) \\
\hline M, 66 & Gruczolakorak BNO & Skóra (ucho) & Rak płaskonabłonkowy & Meta $(+10)$ \\
\hline $\mathrm{K}, 81$ & Rak gruczołowo-torbielowaty & Skóra (ucho) & Rak podstawnokomórkowy & Meta $(-18)$ \\
\hline $\mathrm{K}, 67$ & Rak śluzowo-naskórkowy & Skóra (nos) & Rak płaskonabłonkowy & Meta $(-34)$ \\
\hline M, 57 & RwGW* & Skóra (nos) & Rak podstawnokomórkowy & Meta $(-36)$ \\
\hline M, 73 & Rak śluzowo-naskórkowy & Skóra (nos) & Rak płaskonabłonkowy & Meta $(-280)$ \\
\hline $\mathrm{K}, 75$ & Rak niezróżnicowany & Skóra (nos) & Rak płaskonabłonkowy & Meta (-24) \\
\hline M, 45 & Rak śluzowo-naskórkowy & Tarczyca & Rak brodawkowaty & Syn (0) \\
\hline $\mathrm{K}, 31$ & Rak niezróżnicowany & Żołądek & Gruczolakorak & $\operatorname{Meta}(+55)+$ \\
\hline
\end{tabular}

*RwGW - rak w gruczolaku wielopostaciowym; BNO - bliżej nieokreślony

**Meta - metachroniczny, Syn - synchroniczny. W nawiasach podano czas w miesiącach rozpoznania drugiego pierwotnego nowotworu: (+) po, (-) przed leczeniem nowotworu ślinianki.

t - zgon z powodu drugiego pierwotnego nowotworu 


\subsection{Sposób leczenia}

Spośród 131 chorych, 58 (44,3\%) było leczonych wyłącznie chirurgicznie, u $73(55,7 \%)$ zastosowano leczenie skojarzone (operacja uzupełniona napromienianiami).

Parotidektomia była standardowym zabiegiem, który wykonano u wszystkich analizowanych chorych. U 56 z nich (42,7\%) udało się zachować ciągłość anatomiczną nerwu twarzowego - parotidektomia zachowawcza, która w 39 przypadkach $(29,8 \%)$ polegała na usunięciu płata powierzchownego ślinianki wraz z guzem. Parotidektomię radykalną (wycięcie całej ślinianki przyusznej wraz z nerwem twarzowym) wykonano u 54 chorych $(41,2 \%)$, w tym u 6 konieczna była resekcja dodatkowych struktur otaczających, takich jak przewód słuchowy zewnętrzny, małżowina uszna, mięsień żwacz, część żuchwy. Do parotidektomii radykalnej rozszerzonej nie wliczono zabiegów, podczas których konieczne było wycięcie fragmentu skóry, ale możliwe pierwotne zamknięcie rany. Ponadto u 21 chorych $(16,0 \%)$ wykonano parotidektomię półzachowawczą która polegała na wycięciu niektórych, nacieczonych przez nowotwór gałęzi nerwu twarzowego wraz z guzem i częścią lub całością miąższu ślinianki przyusznej.

U 108 chorych $(82,5 \%)$ wycięcie ślinianki uzupełniono operacją węzłową na szyi, w tym u 66 (spośród 89) z węzłami N0 (zabieg elektywny). Najczęstszym rodzajem operacji węzłowej było selektywne wycięcie węzłów chłonnych poziomów II, III i V (67 chorych - 51,1\%). Radykalne usunięcie węzłów chłonnych szyi (poziomy I-V) wykonano łącznie u 37 chorych $(28,2 \%)$, w tym operację czynnościową (radykalną zmodyfikowana) u 19 pacjentów (14,5\%). W czterech przypadkach $(3,1 \%)$ konieczne było poszerzenie zabiegu o dodatkowe struktury anatomiczne 
(skóra i/lub nerw podjęzykowy i/lub tętnica szyjna zewnętrzna). W tabeli XI wyszczególniono rodzaje parotidektomii z uwzględnieniem zakresu operacji węzłowych na szyi.

Tabela XI

Rodzaj parotidektomii z uwzględnieniem zakresu operacji węzłowej na szyi

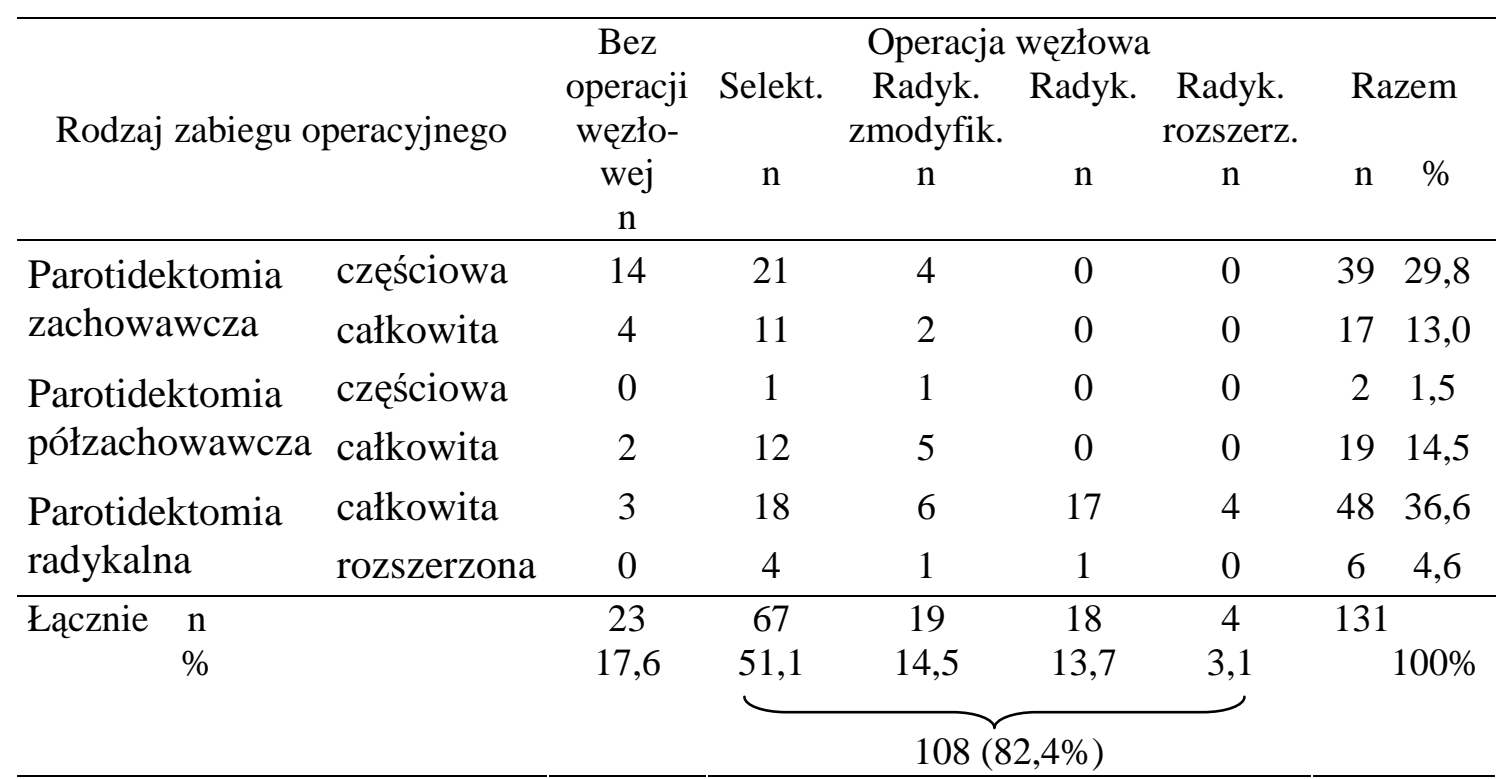

Selekt.- selektywna; Radyk.zmodyfik.- radykalna zmodyfikowana

Radyk.- radykalna; Radyk.rozszerz. -radykalna rozszerzona

U większości chorych leczonych metodą skojarzoną istniało co najmniej jedno wskazanie do uzupełniającej radioterapii. Najczęściej było to wysokie zaawansowanie narządowe (T3/T4) i wysoki stopień złośliwości raka - kolejno 59 i 60 chorych (45,0\% i 45,8\%), ponadto obecność przerzutów do regionalnych węzłów chłonnych (37 przypadków - 28,2\%) oraz dodatni lub wątpliwy margines chirurgiczny (29 chorych - 22,1\%).

Najczęstszym powikłaniem leczenia operacyjnego (parotidektomii zachowawczej lub półzachowawczej) było zaburzenie czynności nerwu twarzowego (45 spośród 77 chorych - 58,4\%). U pacjentów po parotidektomii z całkowitym zachowaniem ciągłości nerwu twarzowego, pooperacyjny niedowład tego nerwu wystąpił u 25 z 56 z nich (44,6\%), w tym u wszystkich 17 pacjentów po całkowitym usunięciu 
miąższu ślinianki przyusznej. U pacjentów, którym resekowano część nerwu, niedowład pozostałych gałęzi obserwowano u 20 z 21 chorych (95,2\%), przy czym u 19 po parotidektomi całkowitej. Ostatecznie trwałe zaburzenie czynności nerwu twarzowego o różnym stopniu nasilenia, wystąpiło u wszystkich 54 chorych po operacji radykalnej (porażenie) oraz u 6 pacjentów (7,8\%) po zabiegu zachowawczym lub półzachowawczym (pozostawionych gałęzi). Krwiak w ranie, zakażenie lub martwica płata skórnego obserwowano łącznie w 19 przypadkach (14,5\%). Kolejnym powikłaniem, które dotyczyło 11 chorych $(8,4 \%)$, była przetoka ślinowa lub retencja śliny w ranie. Szczękościsk wystapił u 7 pacjentów, w tym u 2 bez uprzednich zaburzeń w otwierania jamy ustnej. W toku dalszej obserwacji u 11 chorych rozpoznano pocenie smakowe (zespół Frey).

W analizowanej grupie 131 chorych $\mathrm{z}$ rakiem ślinianki przyusznej rozpoznano na podstawie badania histologicznego materiału operacyjnego 14 różnych typów histologicznych. Dominowały raki o wysokim stopniu złośliwości - 89 przypadków (67,9\%), raki o pośrednim i niskim stopniu złośliwości stwierdzono odpowiednio u $8(6,1 \%)$ i $34(25,9 \%)$ chorych.

Najczęstszym nowotworem był gruczolakorak (bliżej nieokreślony) oraz rak w gruczolaku wielopostaciowym - po 25 przypadków (19,0\%), następnie rak śluzowo-naskórkowy, który rozpoznano u 24 chorych (18,3\%) oraz rak gruczołowotorbielowaty (19 przypadków - 14,5\%). Rak zrazikowokomórkowy, niezróżnicowany i płaskonabłonkowy występowały rzadziej, odpowiednio u 11, 9 i 7 chorych $(8,4 \%, 6,9 \%, 5,3 \%)$. Pozostałe siedem podtypów raków rozpoznano łącznie u 11 pacjentów $(8,4 \%)$. Utkanie histologiczne raków ślinianki przyusznej z uwzględnieniem stopnia złośliwości przedstawiono w tabeli XII. 
Tabela XII

Utkanie histologiczne raków ślinianki przyusznej z uwzględnieniem stopnia złośliwości

\begin{tabular}{lccccc}
\hline \multirow{2}{*}{ Utkanie histologiczne } & WSZ & PSZ & NSZ & \multicolumn{2}{c}{ Całość } \\
& $\mathrm{n}$ & $\mathrm{n}$ & $\mathrm{n}$ & $\mathrm{n}$ & $\%$ \\
\hline Gruczolakorak BNO & 18 & & 7 & 25 & 19,0 \\
Rak w gruczolaku wielopostaciowym & 25 & & & 25 & 19,0 \\
Rak śluzowo-naskórkowy & 15 & & 9 & 24 & 18,3 \\
Rak gruczołowo-torbielowaty & 14 & 5 & & 19 & 14,5 \\
Rak zrazikowokomórkowy & & & 11 & 11 & 8,4 \\
Rak niezróżnicowany* & 7 & 2 & & 9 & 6,9 \\
Rak płaskonabłonkowy & 7 & & & 7 & 5,3 \\
Rak przewodowy ślinianek & 3 & & & 3 & 2,3 \\
Rak nabłonkowo-mioepitelialny & & & 2 & 2 & 1,5 \\
Torbielakogruczolakorak & & & 2 & 2 & 1,5 \\
Gruczolakorak podstawnokomórkowy & & & 1 & 1 & 0,8 \\
Rak jasnokomórkowy BNO & & & 1 & 1 & 0,8 \\
Gruczolakorak śluzowy & & & 1 & 1 & 0,8 \\
Rak łojowy & & 1 & & 1 & 0,8 \\
\hline Łącznie & 89 & 8 & 34 & 131 & 100 \\
\hline
\end{tabular}

* Podtypy: large cell carcinoma o wysokim stopniu złośliwości (6); small cell carcinoma o wysokim stopniu złośliwości (1); lymphoepithelial carcinoma o pośrednim stopniu złośliwości (2)

BNO - bliżej nieokreślony; WSZ - wysoki stopień złośliwości; PSZ - pośredni stopień złośliwości,

NSZ - niski stopień złośliwości

Komponenta złośliwa w obrębie raka w gruczolaku wielopostaciowym miała u 12 chorych utkanie gruczolakoraka (bliżej nieokreślonego), u 9 raka niezróżnicowanego, a u 4 chorych raka śluzowo-naskórkowego. Na rycinie 2 przedstawiono odsetki poszczególnych typów histologicznych raków ślinianki przyusznej.

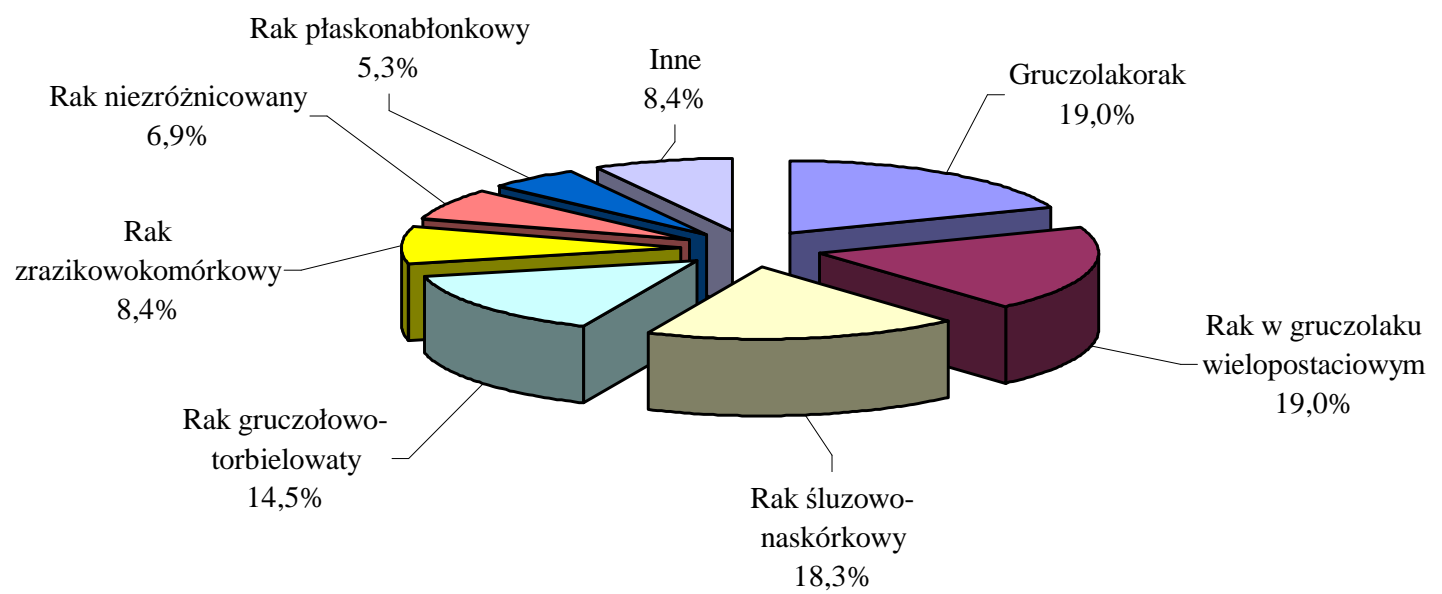

Ryc. 2. Typy histologiczne raków ślinianki przyusznej 
W najczęściej występującym gruczolakoraku (bliżej nieokreślonym) oraz w raku w gruczolaku wielopostaciowym, przeważali chorzy w IV stopniu zaawansowania klinicznego (odpowiednio 17 i 15 przypadków). W tabeli XIII przedstawiono zaawansowanie kliniczne z uwzględnieniem budowy histologicznej.

\section{Tabela XIII}

Zaawansowanie kliniczne z uwzględnieniem budowy histologicznej

\begin{tabular}{lccccc}
\hline Utkanie histologiczne & I & II & III & IV & Razem \\
\hline Gruczolakorak BNO & 0 & 6 & 2 & 17 & 25 \\
RwGW & 1 & 5 & 4 & 15 & 25 \\
Rak śluzowo-naskórkowy & 1 & 9 & 4 & 10 & 24 \\
Rak gruczołowo-torbielowaty & 5 & 6 & 3 & 5 & 19 \\
Rak zrazikowokomórkowy & 2 & 4 & 1 & 4 & 11 \\
Rak niezróżnicowany & 0 & 2 & 3 & 4 & 9 \\
Rak płaskonabłonkowy & 0 & 1 & 1 & 5 & 7 \\
Inne & 1 & 4 & 4 & 2 & 11 \\
\hline Lącznie n & 10 & 37 & 22 & 62 & 131 \\
\multicolumn{1}{c}{$\%$} & 7,6 & 28,2 & 16,8 & 47,3 & 100 \\
\hline BNO - bliżej nieokreślony & & & & &
\end{tabular}

W grupie 89 chorych z rakami o wysokim stopniu złośliwości dominował IV stopień zaawansowania klinicznego - 52 przypadki $(58,4 \%)$. W II i III stopniu było odpowiednio 20 i 13 pacjentów (22,5\% i 14,6\%). Tylko 4 chorych $(4,5 \%)$ z rakami o wysokim stopniu złośliwości miało I stopień zaawansowania klinicznego. Spośród 42 chorych z rakami o pośrednim lub niskim stopniu złośliwości przeważali chorzy w II stopniu zaawansowania klinicznego - 17 przypadków (40,5\%). 10 pacjentów (23,8\%) miało IV, 9 (21,4\%) - III stopień a $6(14,3 \%)$ - pierwszy stopień zaawansowania klinicznego.

Przerzuty do regionalnych węzłów chłonnych stwierdzono w badaniu histologicznym u 45 spośród 108 chorych (41,7\%), u których wykonano operację węzłową na szyi. Uwzględniając kliniczne zaawansowanie regionalne przerzuty węzłowe występowały u 12 z 22 chorych ze stopniem N1 (54,5\%) i u 13 z 20 ze stopniem N2 
$(65,0 \%)$. Przerzuty w węzłach N0 rozpoznano w 20 na 66 przypadków (30,3\%). Naciek pozatorebkowy węzła chłonnego rozpoznano u 11 spośród 45 chorych z przerzutami węzłowymi $(24,4 \%)$, w tym u 2 spośród 20 pacjentów $(10,0 \%)$ w stopniu N0, u 4 na $12(33,3 \%)$ w N1 oraz u 5 na 13 (38,5\%) w N2. Przerzuty do węzłów chłonnych najczęściej występowały w raku śluzowo-naskórkowym, gruczolakoraku (bliżej nieokreślonym) oraz raku $\mathrm{w}$ gruczolaku wielopostaciowym - odpowiednio u 11, 12 i 9 chorych $(52,4 \%, 50,0 \%$ i 47,4\%), a także u 2 spośród 3 pacjentów z rakiem przewodowym ślinianek. W raku gruczołowo-torbielowatym przerzuty węzłowe stwierdzono jedynie u 2 spośród 14 chorych (14,3\%). W tabeli XIV przedstawiono częstość występowania przerzutów węzłowych w zależności od utkania histologicznego.

Tabela XIV

Przerzuty do węzłów chłonnych w zależności od utkania histologicznego

\begin{tabular}{lcc}
\hline Utkanie histologiczne & \multicolumn{2}{c}{$\begin{array}{c}\text { Przerzuty do węzłów } \\
\text { chłonnych }\end{array}$} \\
& $\mathrm{n}$ & $\%$ \\
\hline Gruczolakorak BNO & $12 / 24$ & 50,0 \\
RwGW & $9 / 19$ & 47,4 \\
Rak śluzowo-naskórkowy & $11 / 21$ & 52,4 \\
Rak gruczołowo-torbielowaty & $2 / 14$ & 14,3 \\
Rak zrazikowokomórkowy & $2 / 8$ & \\
Rak niezróżnicowany & $3 / 8$ \\
Rak płaskonabłonkowy & $2 / 6$ \\
Rak przewodowy ślinianek & $2 / 3$ \\
Inne & $2 / 5$ \\
\hline BNO - bliżej nieokreślony; RwGW - rak w gruczolaku wielopostaciowym
\end{tabular}

Odsetek chorych z przerzutami do węzłów chłonnych różnił się również w zależności od stopnia złośliwości raków. W nowotworach o wysokim stopniu złośliwości przerzuty węzłowe stwierdzono u 39 spośród 77 chorych (50,6\%), natomiast w grupie pacjentów z rakami o pośrednim i niskim stopniu złośliwości u 6 z 31 pacjentów $(19,3 \%)$. W rakach o wysokim stopniu złośliwości przerzuty do węzłów 
chłonnych występowały u 16 spośród 46 chorych (34,8\%) bez klinicznie powiększonych węzłów chłonnych, u 11 z 15 w stopniu N1 (73,3\%) oraz u 12 z 16 w N2 $(75,0 \%)$. W rakach o niskim i pośrednim stopniu złośliwości zajęcie węzłów chłonnych stwierdzono u 6 spośród 28 chorych $(21,4 \%)$, w tym u 4 na 20 (20,0\%) z N0. Odsetek chorych z przerzutami do węzłów chłonnych był wyraźnie zróżnicowany w zależności od stopnia zaawansowania narządowego. Wahał się on od 14,3\% u chorych z T1 do 50,9\% w stopniu T4. Obserwowano niewielką różnicę między drugim i trzecim stopniem zaawansowania narządowego - odpowiednio 34,5\% i 36,8\%. Zwraca również uwagę częste występowanie utajonych przerzutów węzłowych zarówno w stopniu T4 (10 z 29 chorych, 34,5\%) jak i T2 (8 z 23 chorych, 34,8\%). W tabeli XV przedstawiono przerzuty do węzłów chłonnych w zależności od zaawansowania narządowego z uwzględnieniem zaawansowania regionalnego.

Tabela XV

Przerzuty do węzłów chłonnych w zależności od zaawansowania narządowego z uwzględnieniem zaawansowania regionalnego

\begin{tabular}{lccccc}
\hline & N0 & N1 & N2 & \multicolumn{2}{c}{ Razem N } \\
\hline T1 & $0 / 5$ & $1 / 2$ & $-/-$ & $1 / 7$ & $14,3 \%$ \\
T2 & $8 / 23$ & $1 / 5$ & $1 / 1$ & $10 / 29$ & $34,5 \%$ \\
T3 & $2 / 9$ & $2 / 4$ & $3 / 6$ & $7 / 19$ & $36,8 \%$ \\
T4 & $10 / 29$ & $8 / 11$ & $9 / 13$ & $27 / 53$ & $50,9 \%$ \\
\hline Łącznie & $20 / 66$ & $12 / 22$ & $13 / 20$ & $45 / 108$ & $41,7 \%$ \\
\hline
\end{tabular}




\subsection{Wyniki leczenia}

Ustalenie wyników leczenia na podstawie 5-letniego przeżycia możliwe było u 109 spośród 131 chorych $(83,2 \%)$. W tabeli XVI i na rycinie 3 przedstawiono całkowity czas przeżycia (overall survival, OS), przeżycie bezobjawowe (disease-free survival, DFS) oraz zależne od choroby (disease-specific survival, DSS). 10- i 15letnie przeżycie są wartościami szacunkowymi, gdyż zostały częściowo oparte na niepełnych (uciętych) obserwacjach.

\section{Tabela XVI}

Całkowity czas przeżycia, przeżycie bezobjawowe oraz zależne od choroby

\begin{tabular}{lccc}
\hline & 5 lat & 10 lat & 15 lat \\
\hline Przeżycie całkowite (OS) & $57,0 \%$ & $34,0 \%$ & $24,0 \%$ \\
Przeżycie zależne od choroby (DSS) & $57,0 \%$ & $51,0 \%$ & $45,0 \%$ \\
Przeżycie bezobjawowe (DFS) & $50,0 \%$ & $41,0 \%$ & $38,0 \%$
\end{tabular}

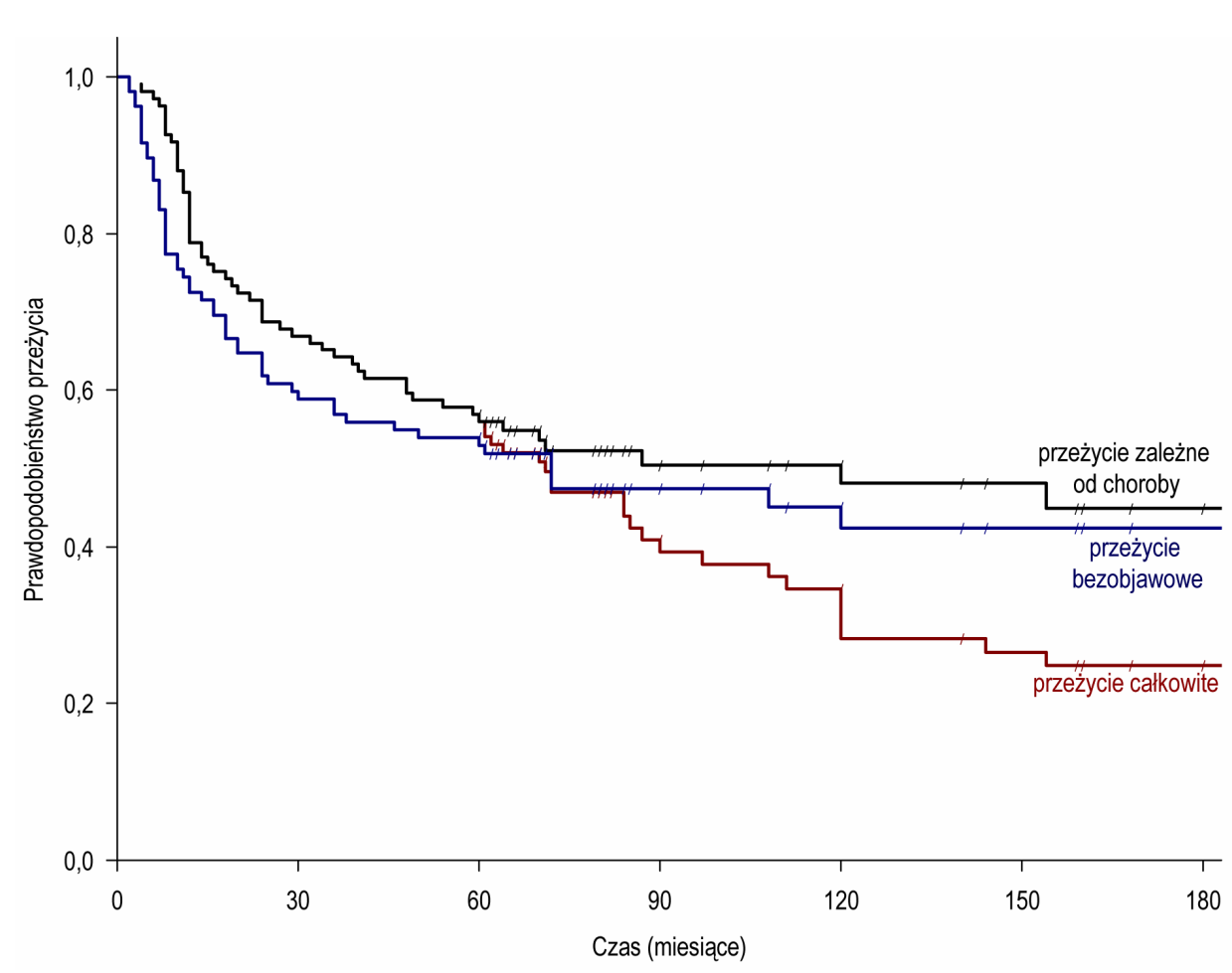

Ryc. 3. Całkowity czas przeżycia, przeżycie bezobjawowe oraz zależne od choroby; Ukośne kreski na wszystkich wykresach przeżycia oznaczają obserwacje ucięte 
W analizowanym materiale 109 chorych 5-letnie przeżycie zależne od choroby oraz przeżycie całkowite wynosiło 57,0\%, natomiast przeżycie bezobjawowe 50,0\%. Szacunkowa wartość 10- i 15-letniego przeżycia bez objawów choroby wynosiła odpowiednio $41,0 \%$ i $38,0 \%$.

5-letnie przeżycie bez objawów choroby (DFS) przyjęto za kryterium wyleczenia, którym posłużono się w dalszej części pracy.

W tabeli XVII i na rycinie 4 przedstawiono wyniki leczenia z uwzględnieniem wieku chorych. 5-letnie DFS uzyskano u 33 chorych $(60,0 \%)$ poniżej 60 roku życia, natomiast w grupie pacjentów w wieku powyżej 60 lat - u 21 (38,9\%). Szansa wyleczenia była 2,4 razy wyższa w grupie pacjentów w wieku poniżej 60 r.ż. w porównaniu do grupy pacjentów powyżej 60 r.ż. Różnice pomiędzy odsetkami przeżyć w obu grupach są statystycznie znamienne.

Tabela XVII

Wyniki leczenia z uwzględnieniem wieku chorych

\begin{tabular}{|c|c|c|c|c|}
\hline \multirow[t]{2}{*}{ Wiek } & \multicolumn{2}{|c|}{ 5- letnie DFS } & \multirow{2}{*}{$\begin{array}{c}\text { OR } \\
(95 \% \mathrm{CI})\end{array}$} & \multirow[t]{2}{*}{$\mathrm{p}$} \\
\hline & $\mathrm{n}$ & $\%$ & & \\
\hline$<60$ lat & 33 & 60,0 & \multirow{3}{*}{$\begin{array}{c}2,4 \\
(1,1-5,1)\end{array}$} & \multirow{3}{*}{0,027} \\
\hline$(\mathrm{n}=55)$ & & & & \\
\hline $\begin{array}{l}\geq 60 \text { lat } \\
(n=54)\end{array}$ & 21 & 38,9 & & \\
\hline
\end{tabular}




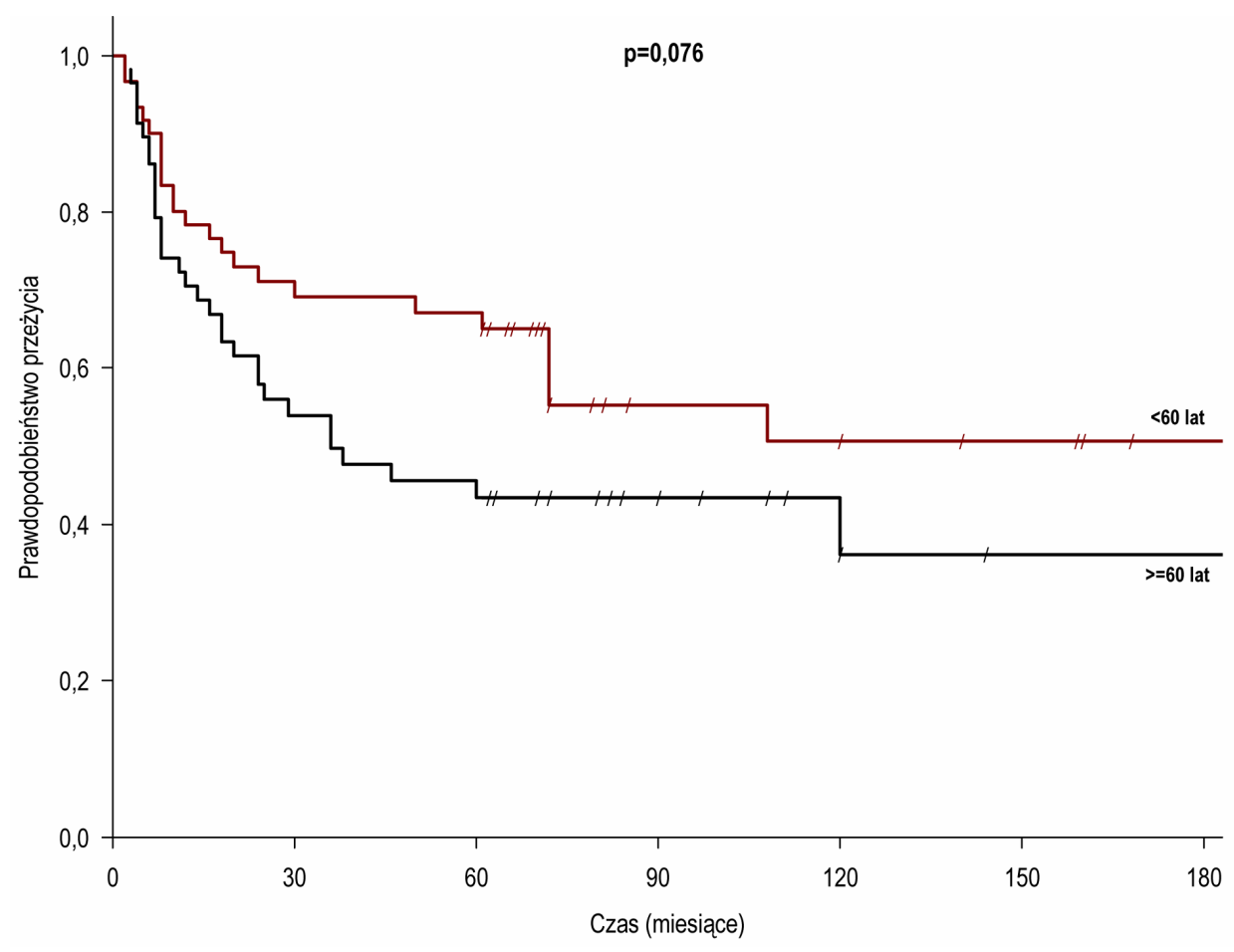

Ryc. 4. Wyniki leczenia z uwzględnieniem wieku chorych

W tabeli XVIII i na rycinie 5 przedstawiono wyniki leczenia z uwzględnieniem płci chorych. 5-letnie przeżycie bezobjawowe stwierdzono u 34 na 56 kobiet (60,7\%), i u 20 spośród 53 mężczyzn (37,7\%). Szansa wyleczenia była 2,6 razy większa w grupie kobiet w porównaniu z grupą mężczyzn. Różnice pomiędzy odsetkami przeżyć w obu grupach są statystycznie znamienne.

Tabela XVIII

Wyniki leczenia z uwzględnieniem płci chorych

\begin{tabular}{|c|c|c|c|c|}
\hline \multirow[t]{2}{*}{ Płeć } & \multicolumn{2}{|c|}{ 5- letnie DFS } & \multirow{2}{*}{$\begin{array}{c}\text { OR } \\
(95 \% \mathrm{CI})\end{array}$} & \multirow{2}{*}{$\mathrm{p}$} \\
\hline & $\mathrm{n}$ & $\%$ & & \\
\hline Kobiety & 34 & 60,7 & \multirow{2}{*}{$\begin{array}{c}2,6 \\
(1,2-5,5)\end{array}$} & \multirow[b]{2}{*}{0,016} \\
\hline $\begin{array}{l}\text { Mężczyźni } \\
(\mathrm{n}=53)\end{array}$ & 20 & 37,7 & & \\
\hline
\end{tabular}




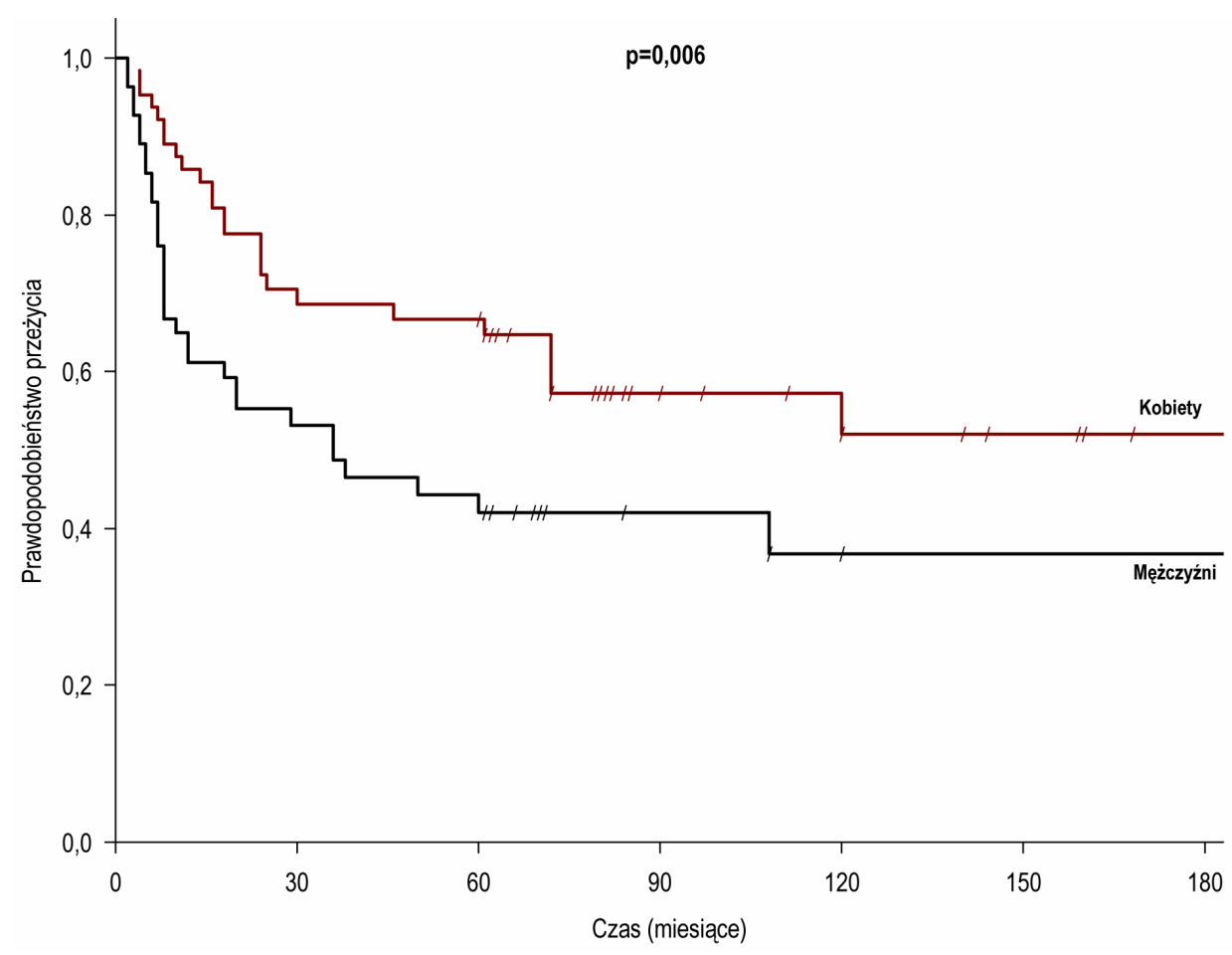

Ryc. 5. Wyniki leczenia z uwzględnieniem płci chorych

Przeanalizowano związek między objawami i odchyleniami w badaniu klinicznym a wynikami leczenia. W tabeli XIX i na rycinie 6 przedstawiono wyniki leczenia z uwzględnieniem dynamiki wzrostu guza. Wyleczenie uzyskano u 26 na 54 $(48,1 \%)$ z szybkim i u 28 spośród 55 chorych $(50,9 \%)$ z powolnym wzrostem guza. Szansa 5-letniego przeżycia była porównywalna w obu grupach. Różnice pomiędzy odsetkami przeżyć w obu grupach są statystycznie nieznamienne.

Tabela XIX

Wyniki leczenia z uwzględnieniem dynamiki wzrostu guza

\begin{tabular}{ccccc}
\hline Wzrostu guza & \multicolumn{2}{c}{ 5- letnie DFS } & OR & $\mathrm{p}$ \\
& $\mathrm{n}$ & $\%$ & $(95 \% \mathrm{CI})$ & \\
\hline $\begin{array}{c}\text { Szybki } \\
(\mathrm{n}=54)\end{array}$ & 26 & 48,1 & & \\
$\begin{array}{c}\text { Powolny } \\
(\mathrm{n}=55)\end{array}$ & 28 & 50,9 & $\begin{array}{c}1,1 \\
(0,5-2,4)\end{array}$ & 0,773 \\
\hline
\end{tabular}

DFS disease- free survival, przeżycie bezobjawowe; OR - iloraz szans; 95\% CI - 95\% przedział ufności dla OR 


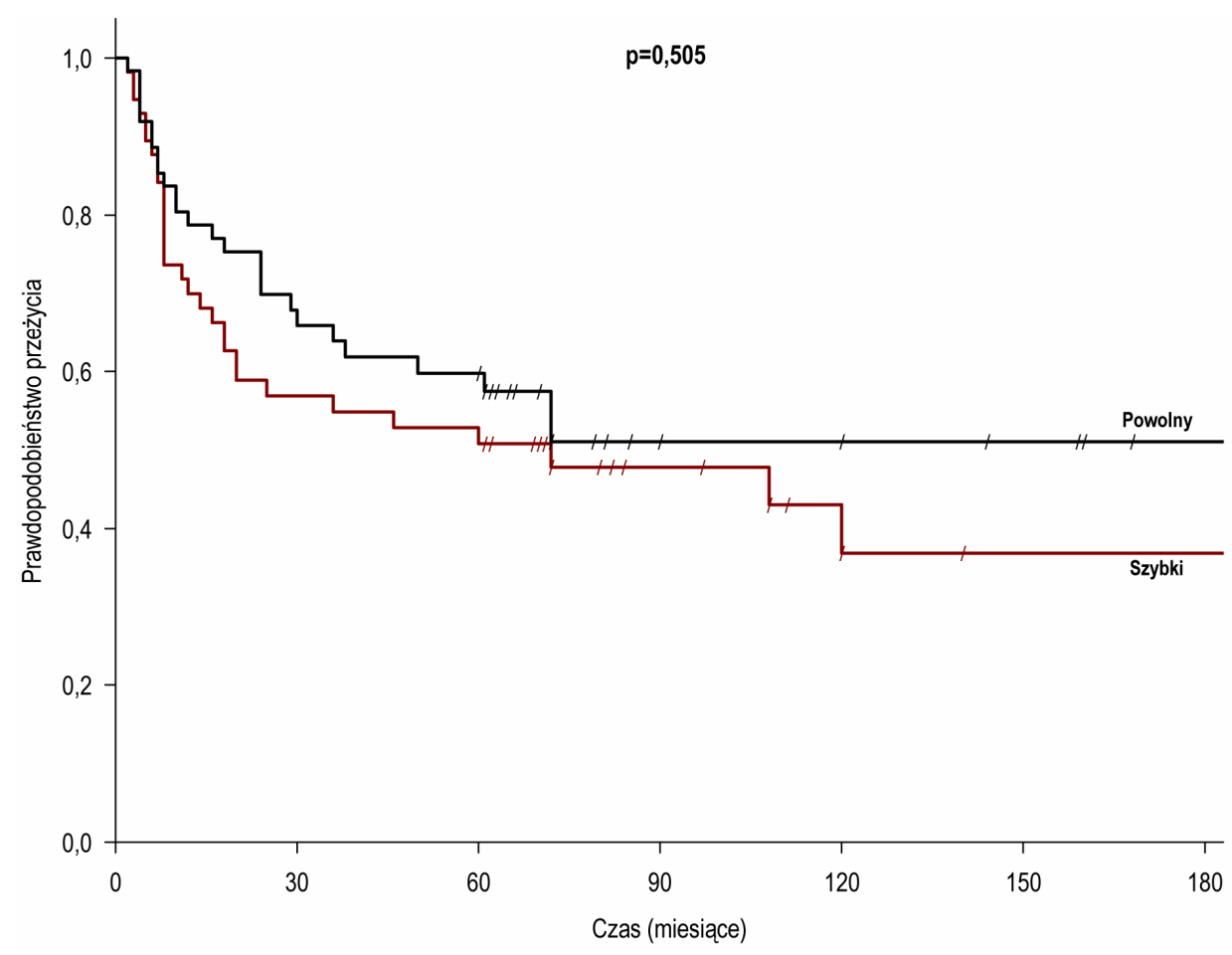

Ryc. 6. Wyniki leczenia z uwzględnieniem dynamiki wzrostu guza

Kolejnym analizowanym objawem był ból w okolicy guza, twarzy lub otalgia. $\mathrm{W}$ tabeli $\mathrm{XX}$ i na rycinie 7 przedstawiono wyniki leczenia $\mathrm{z}$ uwzględnieniem występowania dolegliwości bólowych. Wyleczenie uzyskano u 35 na 64 (54,7\%) bez i u 19 spośród 45 chorych $(42,2 \%)$ z dolegliwościami bólowymi. Szansa 5-letniego bezobjawowego przeżycia była porównywalna w obu grupach. Różnice pomiędzy odsetkami przeżyć w obu grupach są statystycznie nieznamienne.

Tabela XX

Wyniki leczenia w zależności od występowanie objawów bólowych

\begin{tabular}{|c|c|c|c|c|}
\hline \multirow[t]{2}{*}{ Ból } & \multicolumn{2}{|c|}{ 5- letnie DFS } & \multirow{2}{*}{$\begin{array}{c}\text { OR } \\
(95 \% \mathrm{CI})\end{array}$} & \multirow{2}{*}{$\mathrm{p}$} \\
\hline & $\mathrm{n}$ & $\%$ & & \\
\hline Nie & 35 & 54,7 & & \\
\hline $\begin{array}{c}(\mathrm{n}=64) \\
\text { Tak } \\
(\mathrm{n}=45)\end{array}$ & 19 & 42,2 & $\begin{array}{c}1,7 \\
(0,8-3,6)\end{array}$ & 0,200 \\
\hline
\end{tabular}




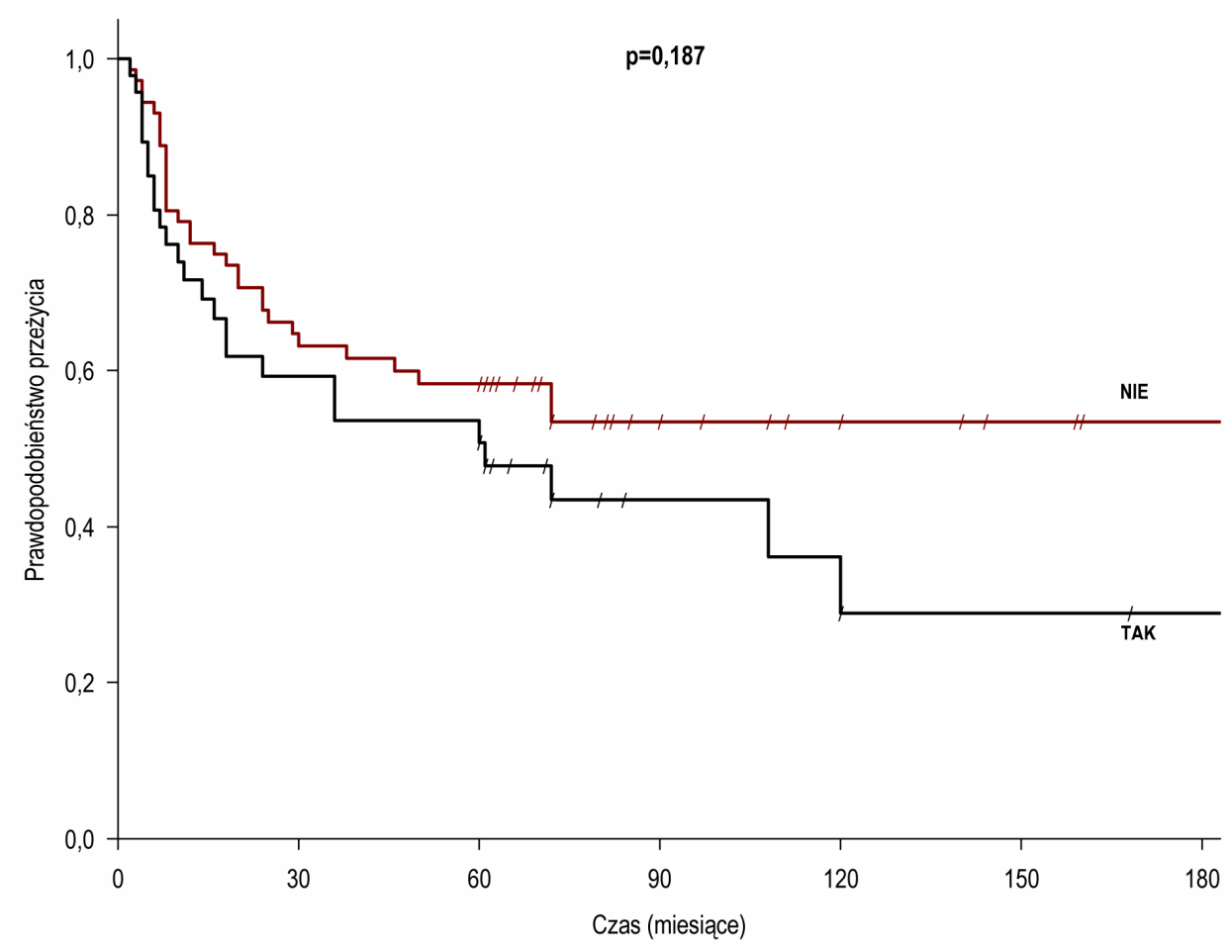

Ryc. 7. Wyniki leczenia w zależności od występowanie objawów bólowych

Kolejną badaną cechą było zaburzenie czynności nerwu twarzowego pod postacią niedowładu lub porażenia. W tabeli XXI i na rycinie 8 przedstawiono wyniki leczenia z uwzględnieniem czynności nerwu twarzowego. Wyleczenie uzyskano u 51 na 86 chorych $(59,3 \%)$ z prawidłową czynnością nerwu i jedynie u 3 spośród 23 $(13,0 \%)$ z jego niedowładem lub porażeniem. Zaburzenie czynności nerwu twarzowego było jednym z czynników najsilniej wpływających na wyniki leczenia, gdyż szansa 5-letniego bezobjawowego przeżycia była 9,7 razy wyższa w grupie pacjentów bez niedowładu bądź porażenia w porównaniu z grupą z zaburzoną czynnością nerwu. Różnice pomiędzy odsetkami przeżyć w obu grupach są statystycznie znamienne. 
Tabela XXI

Wyniki leczenia z uwzględnieniem czynności nerwu twarzowego

\begin{tabular}{ccccc}
\hline $\begin{array}{c}\text { Czynność nerwu } \\
\text { twarzowego }\end{array}$ & \multicolumn{2}{c}{5 - letnie DFS } & $\begin{array}{c}\text { OR } \\
(95 \% \mathrm{CI})\end{array}$ & $\mathrm{p}$ \\
\hline $\begin{array}{c}\text { Prawidłowa } \\
(\mathrm{n}=86)\end{array}$ & 51 & 59,3 & & \\
$\begin{array}{c}\text { Zaburzona } \\
(\mathrm{n}=23)\end{array}$ & 3 & 13,0 & $(2,7-35,2)$ & 0,0008 \\
\hline
\end{tabular}

DFS disease- free survival, przeżycie bezobjawowe; OR - iloraz szans;

95\% CI - 95\% przedział ufności dla OR

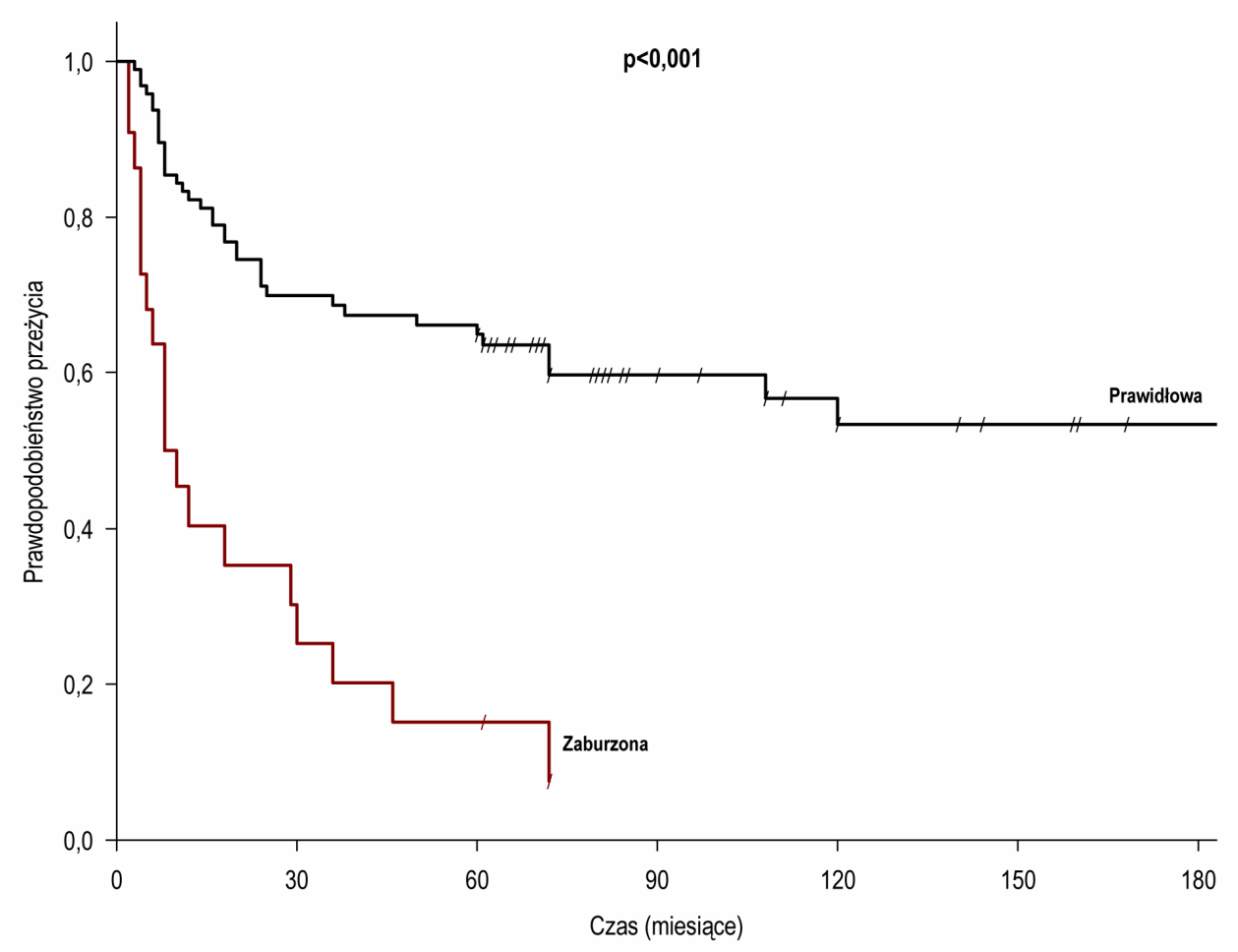

Ryc. 8. Wyniki leczenia z uwzględnieniem czynności nerwu twarzowego

Wyniki leczenia w zależności od naciekania skóry przedstawiono w tabeli XXII i na rycinie 9 . Wyleczenie uzyskano u 49 na 88 chorych $(55,7 \%)$ bez naciekania skóry i u 5 spośród 21 (23,8\%) z jej zajęciem. Szansa wyleczenia była 4,0 razy większa w grupie bez naciekania skóry w porównaniu z grupą chorych z jej zajęciem. Różnice pomiędzy odsetkami przeżyć w obu grupach są statystycznie znamienne. 
Tabela XXII

Wyniki leczenia w zależności od obecności naciekania skóry

\begin{tabular}{ccccc}
\hline Cechy naciekania skóry & \multicolumn{2}{c}{ 5- letnie DFS } & OR & $\mathrm{p}$ \\
& $\mathrm{n}$ & $\%$ & $(95 \% \mathrm{CI})$ & \\
\hline Nie & 49 & 55,7 & & \\
$(\mathrm{n}=88)$ & & & 4,0 & 0,009 \\
$\begin{array}{c}\text { Tak } \\
(\mathrm{n}=21)\end{array}$ & 5 & 23,8 & $(1,4-11,9)$ & \\
\hline
\end{tabular}

DFS disease- free survival, przeżycie bezobjawowe; OR - iloraz szans; 95\% CI - 95\% przedział ufności dla OR

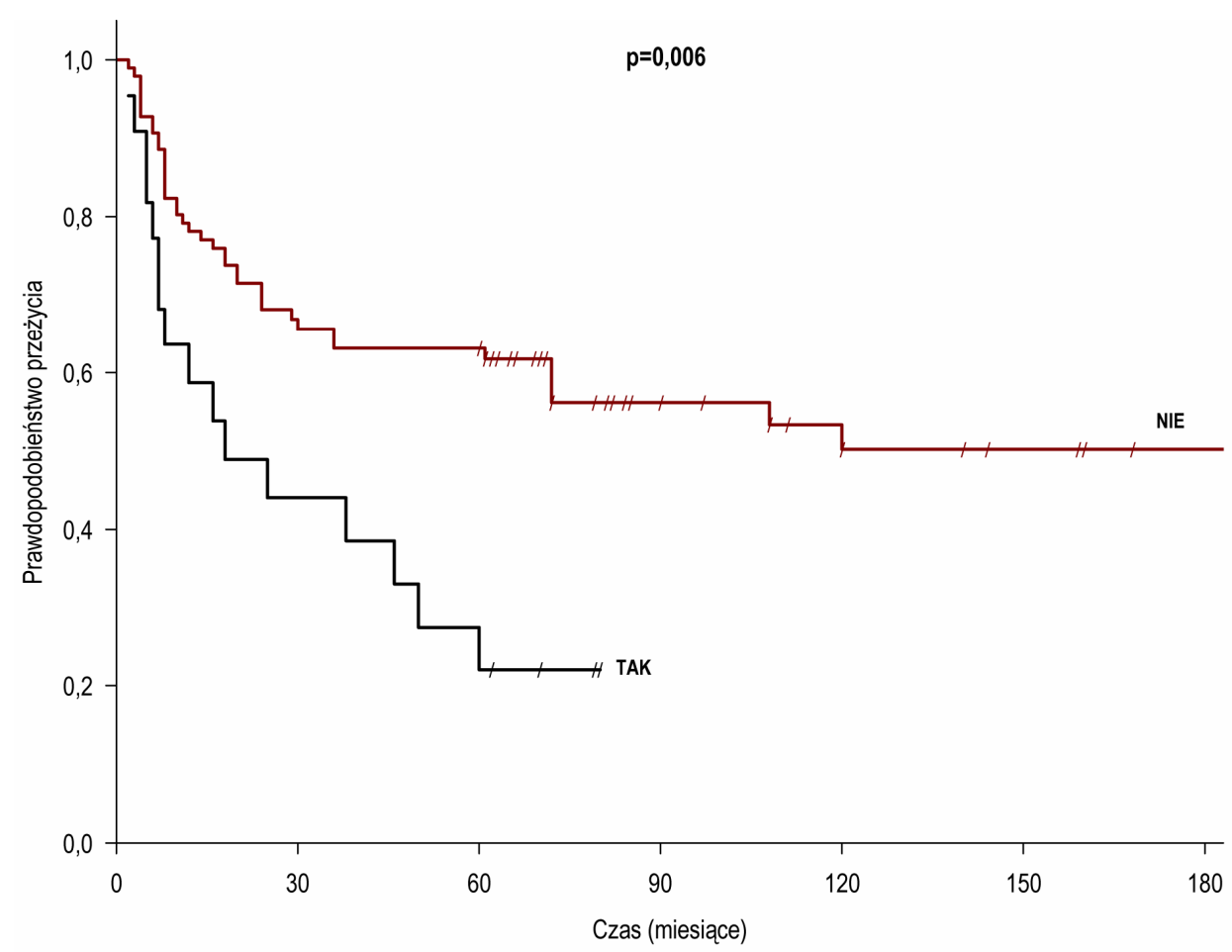

Ryc. 9. Wyniki leczenia w zależności od obecności naciekania skóry

W tabeli XXIII i na rycinie 10 przedstawiono wyniki leczenia w zależności od ruchomości guza. Wyleczenie uzyskano u 41 na 71 chorych $(57,7 \%)$ z przesuwalnym i u 11 spośród $36(30,5 \%)$ z nieruchomym guzem ślinianki. Szansa wyleczenia choroby była 3,1 razy większa w grupie chorych z zachowaną ruchomością guza. Różnice pomiędzy odsetkami przeżyć w obu grupach są statystycznie znamienne. 
Tabela XXIII

Wyniki leczenia w zależności od ruchomości guza

\begin{tabular}{ccccc}
\hline Ruchomość guza & \multicolumn{2}{c}{ 5- letnie DFS } & OR & $\mathrm{p}$ \\
& $\mathrm{n}$ & $\%$ & $(95 \% \mathrm{CI})$ & \\
\hline Nie & 41 & 57,7 & & \\
$\left(\mathrm{n}=71^{*}\right)$ & & & 3,1 & 0,010 \\
$\begin{array}{c}\text { Tak } \\
\left(\mathrm{n}=36^{* *}\right)\end{array}$ & 11 & 30,5 & $(1,3-7,3)$ & \\
\hline
\end{tabular}

DFS disease- free survival, przeżycie bezobjawowe; OR - iloraz szans; 95\% CI - 95\% przedział ufności dla OR

*/**Liczby nie sumują się do 109, gdyż nie u wszystkich chorych stwierdzono klinicznie guz ślinianki przyusznej

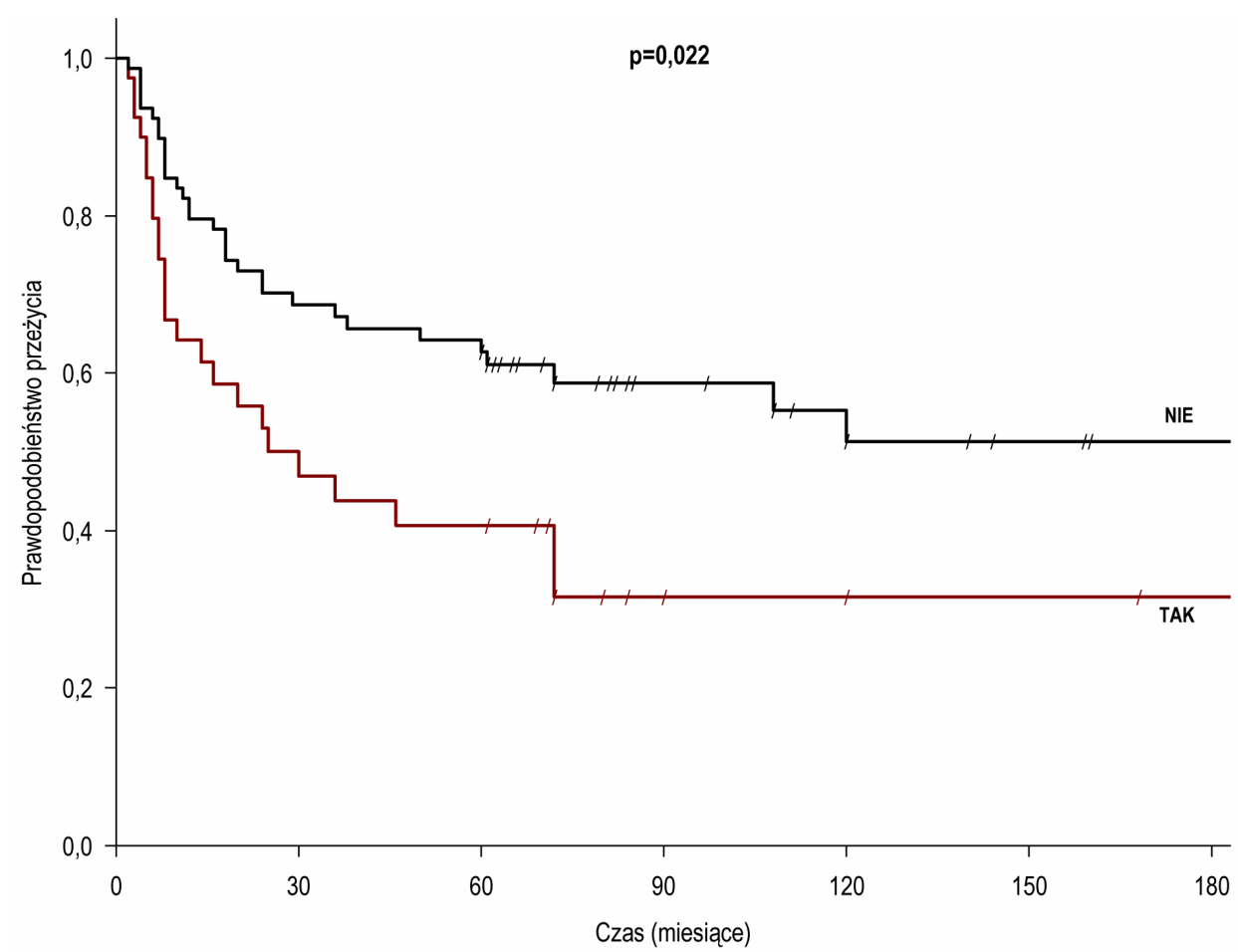

Ryc. 10. Wyniki leczenia w zależności od ruchomości guza

W dalszej kolejności analizowano wpływ powiększenia węzłów chłonnych na 5-letnie bezobjawowe przeżycie, co zostało przedstawione $\mathrm{w}$ tabeli XXIV i na rycinie 11 . Wyleczenie uzyskano u 44 z 75 chorych $(58,7 \%)$ bez powiększonych węzłów chłonnych szyi i u 10 spośród $34(29,4 \%)$ z ich powiększeniem. Szansa 5-letniego bezobjawowego przeżycia była 3,4 razy większa w grupie chorych bez powiększonych węzłów w porównaniu z grupą chorych $\mathrm{z}$ ich powiększeniem. Różnice pomiędzy odsetkami przeżyć w obu grupach są statystycznie znamienne. 
Tabela XXIV

Wyniki leczenia z uwzględnieniem stanu regionalnych węzłów chłonnych

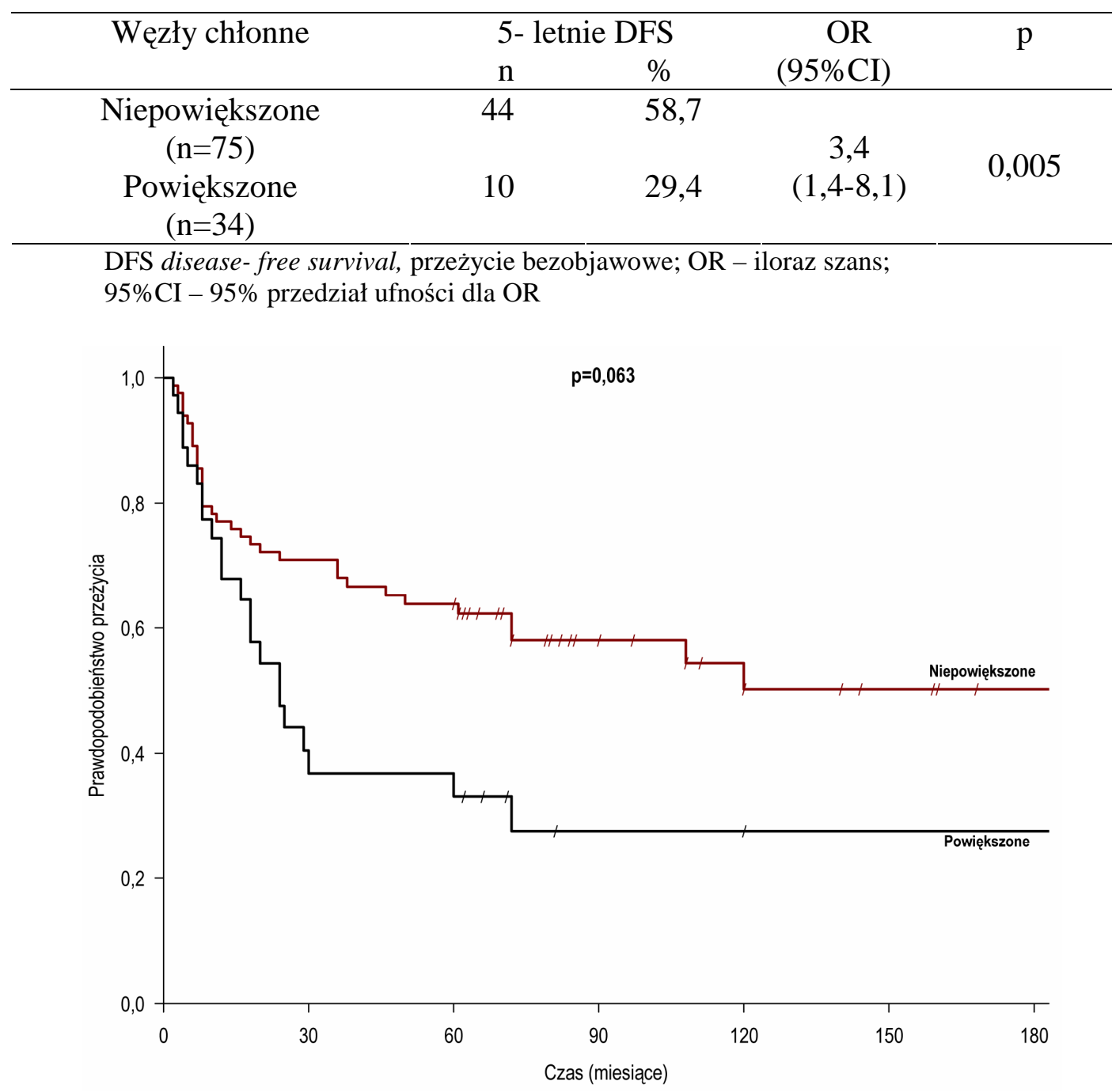

Ryc. 11. Wyniki leczenia z uwzględnieniem stanu regionalnych węzłów chłonnych

W dalszej analizie porównano wyniki leczenia w trzech grupach chorych różniących się liczbą objawów wskazujących na złośliwy charakter nowotworu. 5-letnie przeżycie w grupie chorych bez objawów złośliwości uzyskano u 15/21 (71,4\%), u 29/56 (51,8\%) z 1 lub 2 objawami. Natomiast u chorych z 3 i więcej objawami złośliwości wyleczenie uzyskano u 10/32 (31,2\%). Powyższe dane ilustruje tabela XXV i rycina 12. Różnice pomiędzy odsetkami przeżyć w tych grupach są statystycznie znamienne. 
Tabela XXV

Wyniki leczenia w zależności od liczby objawów złośliwości nowotworu

\begin{tabular}{cccc}
\hline Liczba objawów złośliwości & \multicolumn{2}{c}{5 - letnie DFS } & $\mathrm{p}$ \\
& $\mathrm{n}$ & $\%$ & \\
\hline Bez & 15 & 71,4 & \\
$(\mathrm{n}=21)$ & & & \\
$1-2$ & 29 & 51,8 & 0,001 \\
$(\mathrm{n}=56)$ & & & \\
$\geq 3$ & 10 & 31,2 & \\
$(\mathrm{n}=32)$ & & &
\end{tabular}

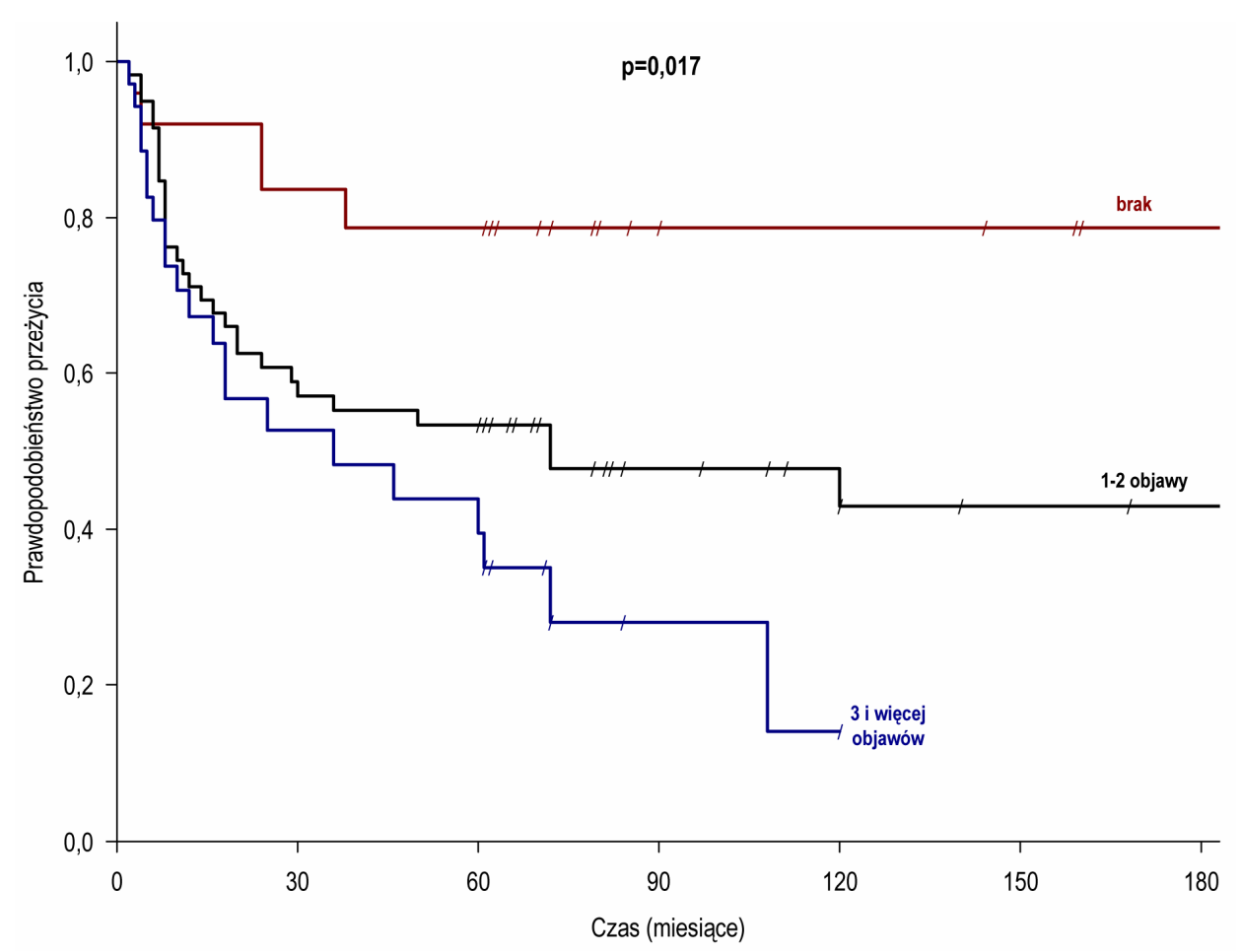

Ryc. 12. Wyniki leczenia w zależności od liczby objawów złośliwości nowotworu

Kolejną badaną cechą wpływającą na wyleczenie była pierwotna lokalizacja nowotworu, co zostało przedstawione w tabeli XXVI i na rycinie 13. 5-letnie bezobjawowe przeżycie stwierdzono u 31 na 49 chorych $(63,2 \%)$ z nowotworem ograniczonym do płata powierzchownego i u 23 spośród 60 pacjentów $(38,3 \%$ ) z zajęciem płata głębokiego lub całego gruczołu ślinianki przyusznej. Szansa wyleczenia była 2,8 większa $\mathrm{w}$ grupie chorych $\mathrm{z}$ guzem zlokalizowanym $\mathrm{w}$ płacie powierzchownym 
w porównaniu z grupą, u której nowotwór obejmował płat głęboki lub cały gruczoł.

Różnice pomiędzy odsetkami przeżyć w obu grupach są statystycznie znamienne.

\section{Tabela XXVI}

Wyniki leczenia raków ślinianki przyusznej w zależności od lokalizacji nowotworu

\begin{tabular}{ccccc}
\hline Lokalizacja & \multicolumn{2}{c}{ 5- letnie DFS } & OR & $\mathrm{p}$ \\
& $\mathrm{n}$ & $\%$ & $(95 \% \mathrm{CI})$ & \\
\hline $\begin{array}{c}\text { Płat powierzchowny } \\
(\mathrm{n}=49)\end{array}$ & 31 & 63,2 & & \\
$\begin{array}{c}\text { Płat głęboki lub cały gruczoł } \\
(\mathrm{n}=60)\end{array}$ & 23 & 38,3 & $(1,3-6,0)$ & 0,009 \\
\hline
\end{tabular}

DFS disease- free survival, przeżycie bezobjawowe; OR - iloraz szans; 95\% CI - 95\% przedział ufności dla OR

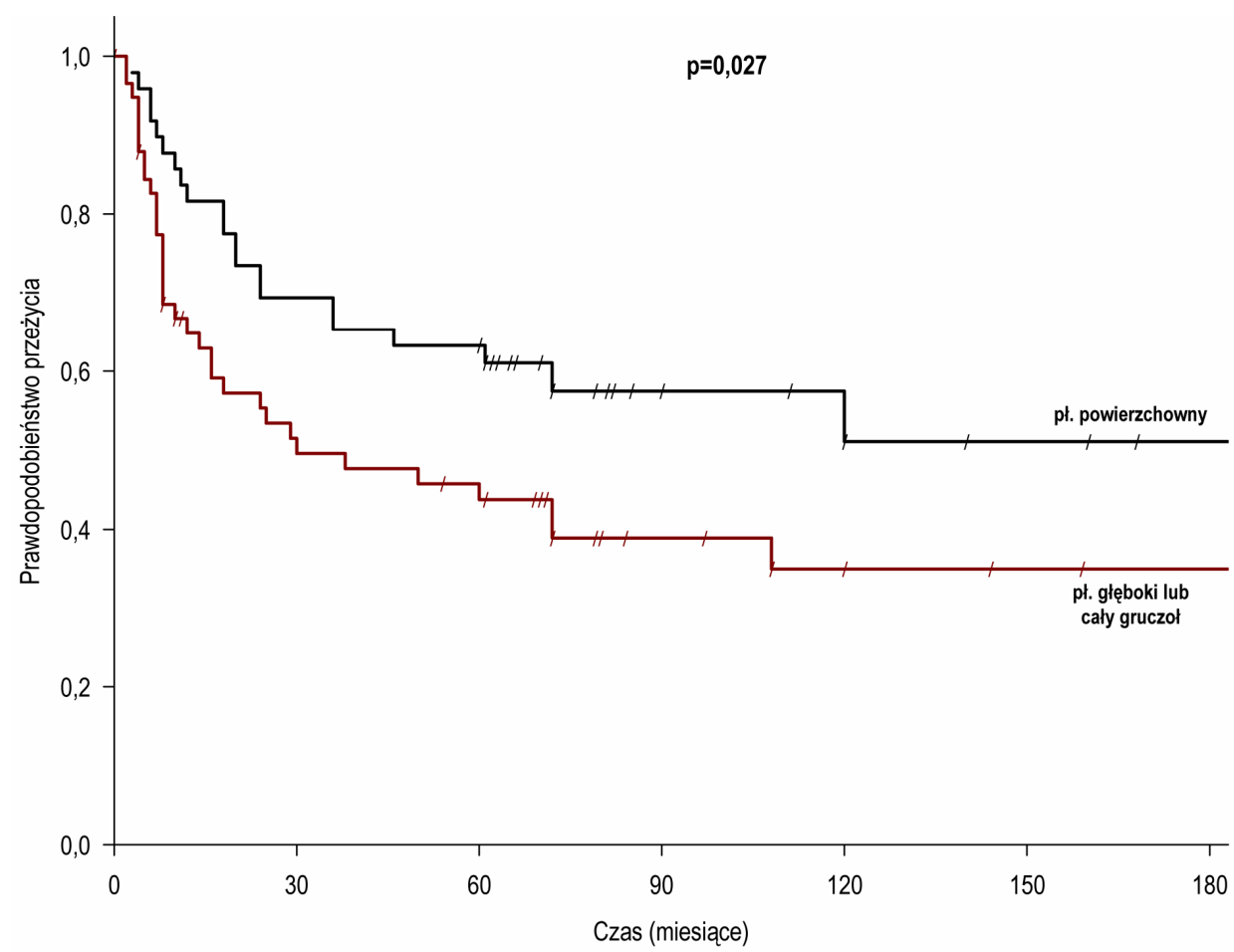

Ryc. 13. Wyniki leczenia w zależności od lokalizacji nowotworu

Wpływ zajęcia przestrzeni przygardłowej na 5-letnie przeżycie bezobjawowe ilustruje tabela XXVII i rycina 14 . Wyleczenie uzyskano u 52 na 92 chorych $(56,5 \%)$ bez zajęcia przestrzeni przygardłowej i u 2 spośród 17 (11,8\%) z jej naciekaniem. 
Zajęcie przestrzeni przygardłowej zmniejszało 9,8 razy szanse na wyleczenie. Różnice pomiędzy odsetkami przeżyć w obu grupach są statystycznie znamienne.

\section{Tabela XXVII}

Wyniki leczenia z uwzględnieniem zajęcia przestrzeni przygardłowej

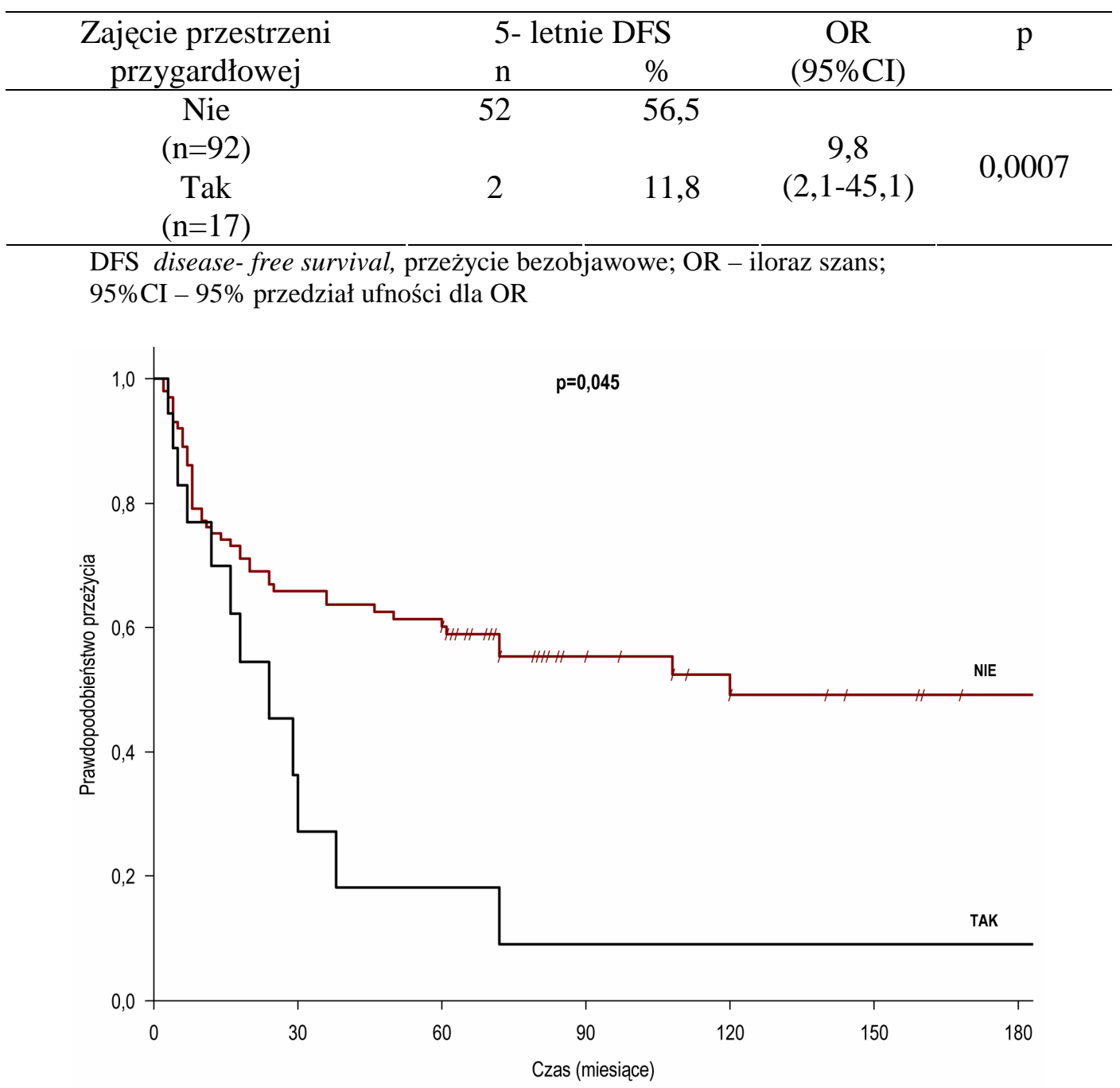

Ryc. 14. Wyniki leczenia z uwzględnieniem zajęcia przestrzeni przygardłowej

Naciekanie przez nowotwór mięśnia żwacza i/lub mięśnia mostkowoobojczykowo-sutkowego i/lub mięśnia dwubrzuścowego było kolejnym analizowanym parametrem. Wyleczenie uzyskano u 48 na 83 chorych $(57,8 \%)$ bez nacieku i u 6 spośród $26(23,1 \%)$ z zajęciem wyżej wymienionych mięśni. Szansa wyleczenia była 3,5 razy większa w grupie chorych bez nacieku mięśni w porównaniu z grupą 
z ich naciekiem. Wyniki leczenia z uwzględnieniem naciekania mięśni w raku ślinianki przyusznej przedstawiono w tabeli XXVIII i na rycinie 15. Różnice pomiędzy odsetkami przeżyć w obu grupach są statystycznie znamienne.

Tabela XXVIII

Wyniki leczenia z uwzględnieniem naciekania mięśni przez nowotwór

\begin{tabular}{ccccc}
\hline Naciekanie mięśni & \multicolumn{2}{c}{5 - letnie DFS } & OR & $\mathrm{p}$ \\
& $\mathrm{n}$ & $\%$ & $(95 \% \mathrm{CI})$ & \\
\hline $\begin{array}{c}\text { Nie } \\
(\mathrm{n}=83)\end{array}$ & 48 & 57,8 & & \\
Tak & & & 3,5 & 0,002 \\
$(\mathrm{n}=26)$ & 6 & 23,1 & $(1,0-11,6)$ & \\
\hline
\end{tabular}

DFS disease-free survival, przeżycie bezobjawowe; OR - iloraz szans; 95\%CI - 95\% przedział ufności dla OR

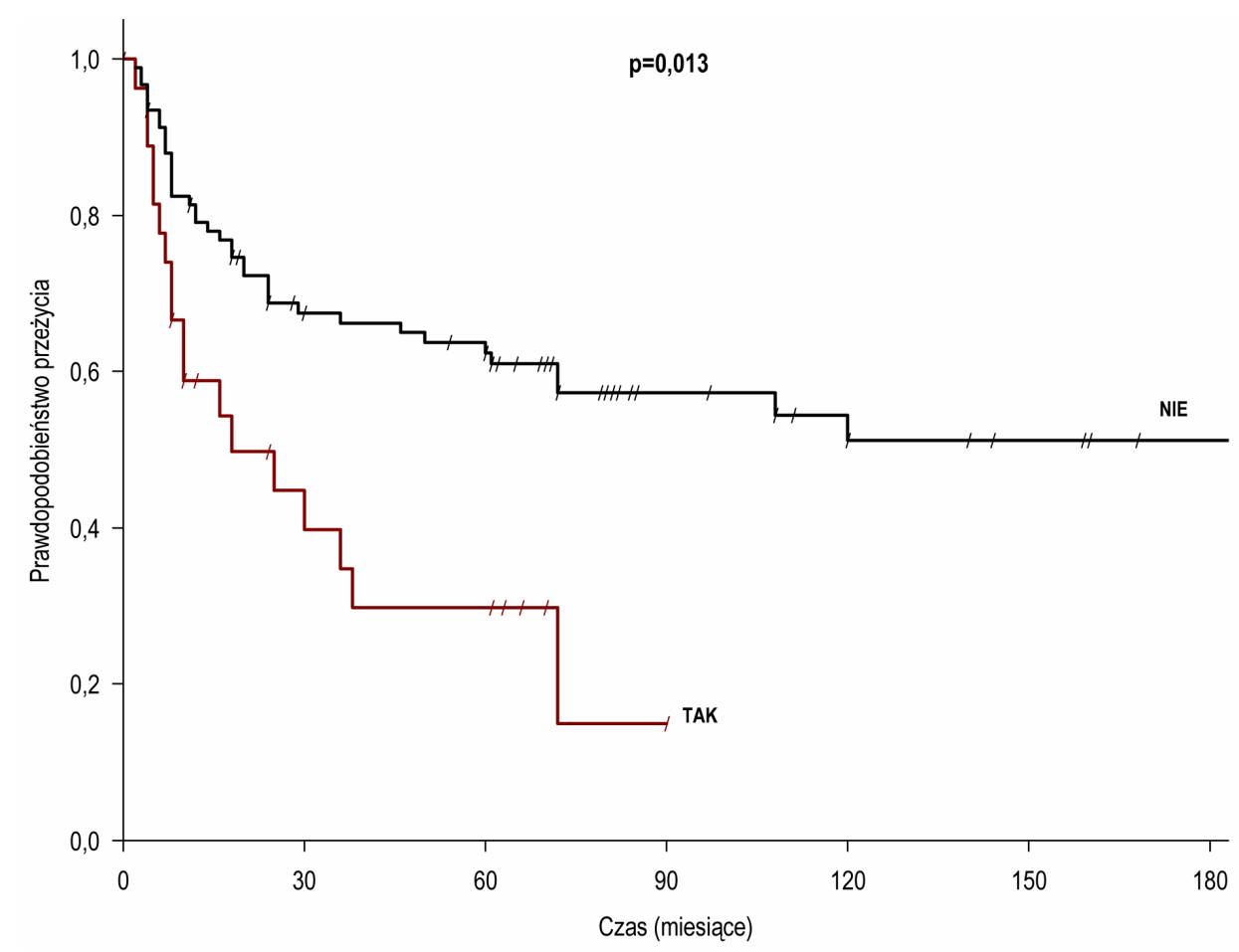

Ryc. 15. Wyniki leczenia z uwzględnieniem naciekania mięśni przez nowotwór

Wpływ naciekania pozagruczołowego raka ślinianki na wyniki leczenia przedstawia tabela XXIX i rycina 16. 5-letnie bezobjawowe przeżycie uzyskano u 40 na 59 chorych $(67,8 \%)$ z nowotworem ograniczonym do miąższu ślinianki 
i u 14 spośród 50 pacjentów $(28,0 \%)$ z naciekaniem pozagruczołowym. Szanse wyleczenia były 5,4 razy większe u chorych, u których nowotwór był ograniczony do miąższu ślinianki w porównaniu z grupą chorych z naciekaniem pozagruczołowym. Różnice pomiędzy odsetkami przeżyć w obu grupach są statystycznie znamienne.

\section{Tabela XXIX}

Wyniki leczenia z uwzględnieniem naciekania pozagruczołowego

\begin{tabular}{|c|c|c|c|c|}
\hline \multirow[t]{2}{*}{ Naciekanie pozagruczołowe } & \multicolumn{2}{|c|}{ 5- letnie DFS } & \multirow{2}{*}{$\begin{array}{c}\text { OR } \\
(95 \% \mathrm{CI})\end{array}$} & \multirow[t]{2}{*}{$\mathrm{p}$} \\
\hline & $\mathrm{n}$ & $\%$ & & \\
\hline $\mathrm{Nie}$ & 40 & 67,8 & & \\
\hline$(\mathrm{n}=59)$ & & & 5,4 & \\
\hline $\begin{array}{c}\text { Tak } \\
(n=50)\end{array}$ & 14 & 28,0 & $(2,4-12,3)$ & 0,0003 \\
\hline
\end{tabular}

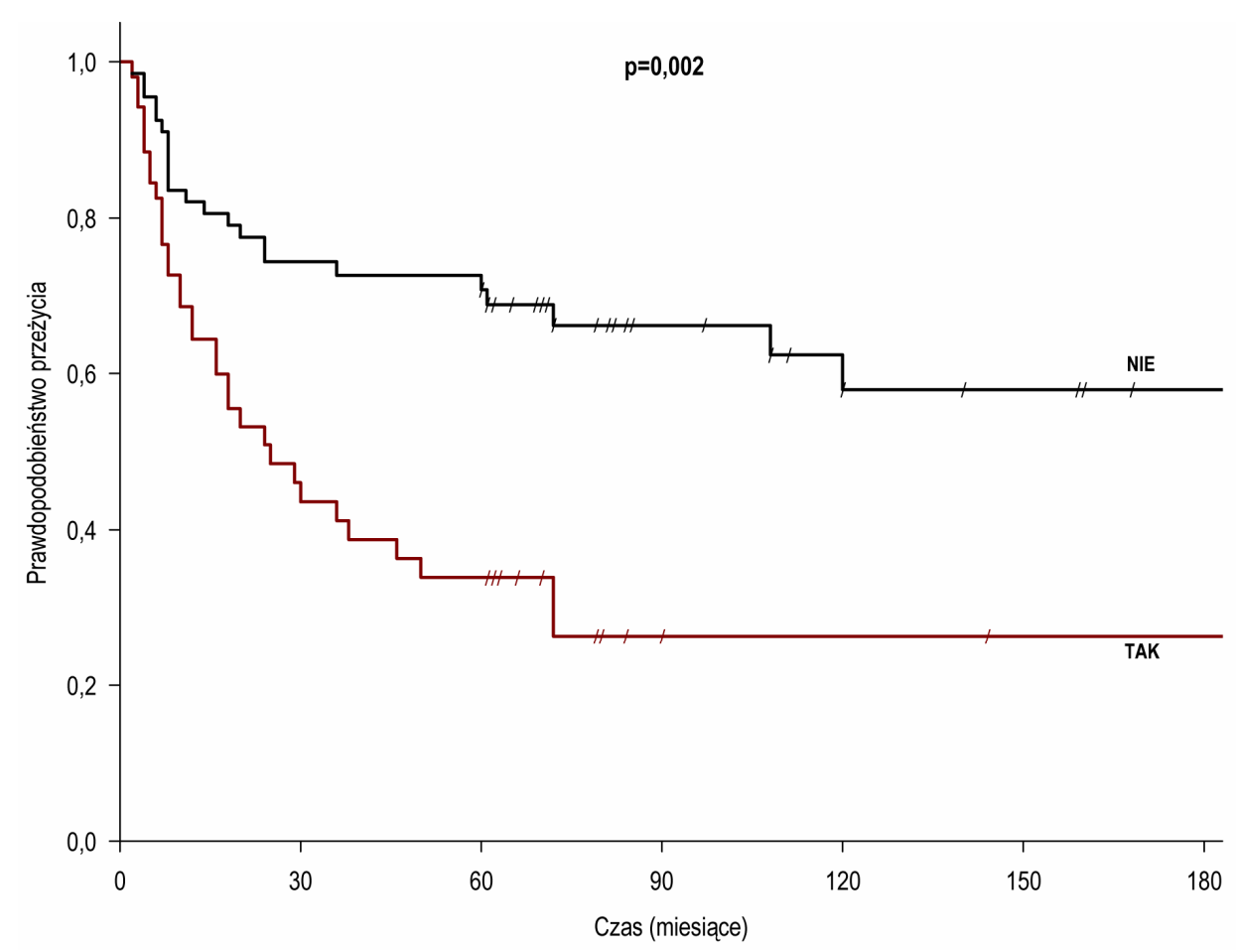

Ryc. 16. Wyniki leczenia z uwzględnieniem naciekania pozagruczołowego

U 43 chorych stwierdzono guz mniejszy niż 4 cm, a u 66 pacjentów większy niż $4 \mathrm{~cm}$. 5-letnie bezobjawowe przeżycie w pierwszej grupie uzyskano u 28 chorych 
$(65,1 \%)$, natomiast w drugiej u 26 pacjentów $(39,4 \%)$. Szansa wyleczenia była 2,9 razy większa u chorych z guzem mniejszym niż $4 \mathrm{~cm}$ w porównaniu z grupą pacjentów z guzem większym niż 4 cm. Różnice pomiędzy odsetkami przeżyć w obu grupach są statystycznie znamienne. Wyniki leczenia w zależności od wielkości guza przedstawiono w tabeli XXX i na rycinie 17.

\section{Tabela XXX}

Wyniki leczenia w zależności od wielkości guza

\begin{tabular}{ccccc}
\hline Wielkość guza & \multicolumn{2}{c}{5 - letnie DFS } & OR & $\mathrm{p}$ \\
& $\mathrm{n}$ & $\%$ & $(95 \% \mathrm{CI})$ & \\
\hline$\leq 4 \mathrm{~cm}$ & 28 & 65,1 & & \\
$(\mathrm{n}=43)$ & & & 2,9 & 0,009 \\
$>4 \mathrm{~cm}$ & 26 & 39,4 & $(1,3-6,4)$ & \\
$(\mathrm{n}=66)$ & & & & \\
\hline
\end{tabular}

DFS disease- free survival, przeżycie bezobjawowe; OR - iloraz szans; 95\% CI - 95\% przedział ufności dla OR

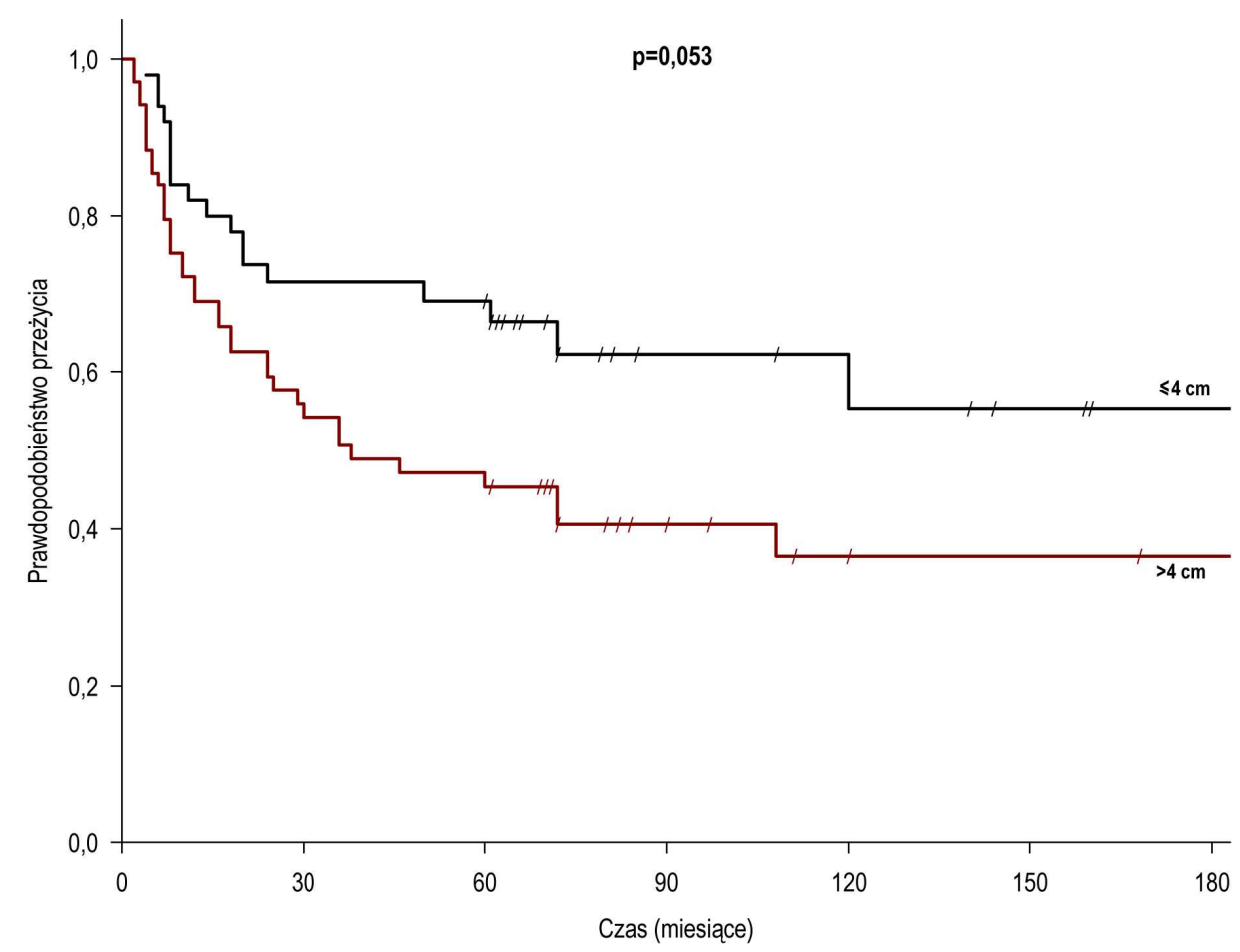

Ryc. 17. Wyniki leczenia w zależności od wielkości guza

Zaawansowanie narządowe było cechą silnie wpływającą na wyleczenie. W stopniu T1 przeżycie bezobjawowe uzyskano w 9/11 przypadków $(81,8 \%)$, w T2 
i T3 odpowiednio u 26/35 i 10/15 pacjentów (74,3\% i 66,7\%). W zaawansowaniu narządowym T4 tylko 9 spośród 48 chorych $(18,7 \%)$ przeżyło 5 lat bez objawów nawrotu choroby. Pacjenci z zaawansowaniem T1-T3 mieli 12,2 razy większą szansę przeżycia w porównaniu z grupą chorych w stopniu T4. Wyniki leczenia w zależności od stopnia zaawansowania narządowego ilustruje tabela XXXI i rycina 18.

\section{Tabela XXXI}

Wyniki leczenia w zależności od stopnia zaawansowania narządowego

\begin{tabular}{ccccc}
\hline Zaawansowanie narządowe & \multicolumn{2}{l}{5 - letnie DFS } & OR & $\mathrm{p}$ \\
& $\mathrm{n}$ & $\%$ & $(95 \% \mathrm{CI})$ & \\
\hline $\mathrm{T} 1$ & 9 & 81,8 & & \\
$(\mathrm{n}=11)$ & & & & \\
$\mathrm{T} 2$ & 26 & 74,3 & 12,2 & 0,0000 \\
$(\mathrm{n}=35)$ & & & & \\
$\mathrm{T} 3$ & 10 & 66,7 & $(4,8-30,7)$ & \\
$(\mathrm{n}=15)$ & & & & \\
$\mathrm{T} 4$ & 9 & 18,7 & \\
$(\mathrm{n}=48)$ & & &
\end{tabular}

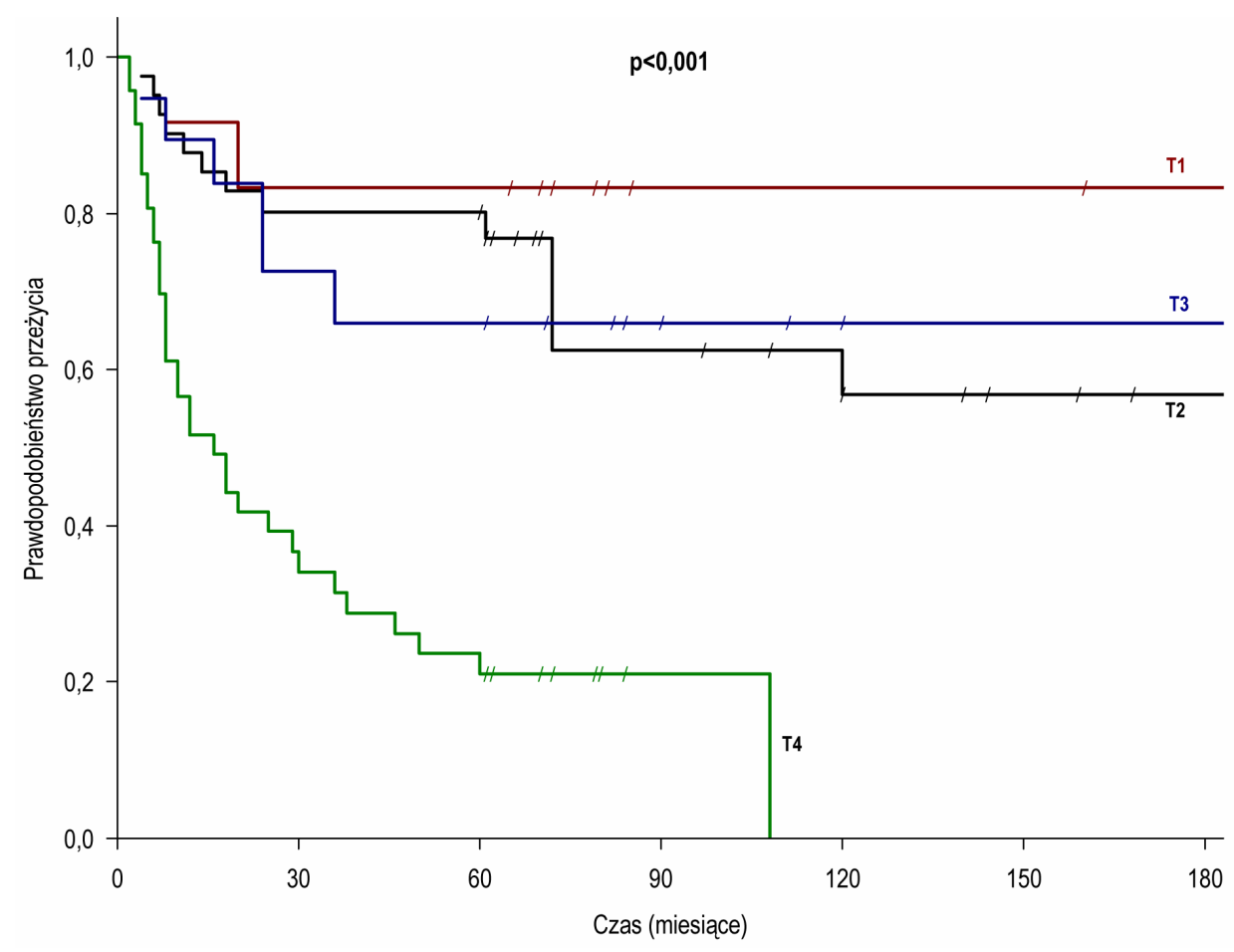

Ryc. 18. Wyniki leczenia w zależności od stopnia zaawansowania narządowego 
Odsetek chorych z 5-letnim przeżyciem bezobjawowym różnił się w zależności od stopnia zaawansowania klinicznego. Wyleczenie uzyskano u 8 na 9 chorych $(88,9 \%)$ w I stopniu i tylko u 11 spośród 52 pacjentów $(21,5 \%)$ w IV stopniu. Zaobserwowano niewielką różnicę w 5-letnim przeżyciu bezobjawowym między II i III stopniem, odpowiednio 22/30 i 13/18 chorych (73,3\% i 73,2\%). Pacjenci z I, II i III stopniem zaawansowania klinicznego mieli 11,4 razy większą szansę na wyleczenie w porównaniu z chorymi z IV stopniem. Wyniki leczenia w zależności od stopnia zaawansowania klinicznego przedstawiono w tabeli XXXII i rycina 19.

Tabela XXXII

Wyniki leczenia w zależności od stopnia zaawansowania klinicznego

\begin{tabular}{ccccc}
\hline Zaawansowanie kliniczne & \multicolumn{2}{c}{5 - letnie DFS } & OR & $\mathrm{p}$ \\
& $\mathrm{n}$ & $\%$ & $(95 \% \mathrm{CI})$ & \\
\hline $\begin{array}{c}\mathrm{I} \\
(\mathrm{n}=9) \\
\mathrm{II} \\
(\mathrm{n}=30) \\
\mathrm{III} \\
(\mathrm{n}=18) \\
\text { IV } \\
(\mathrm{n}=52)\end{array}$ & 8 & 88,9 & & \\
\hline $\begin{array}{l}\text { DFS disease- free survival, przeżycie bezobjawowe; OR - iloraz szans; } \\
\text { 95\%CI - 95\% przedział ufności dla OR }\end{array}$ & 22 & 73,3 & & \\
\end{tabular}




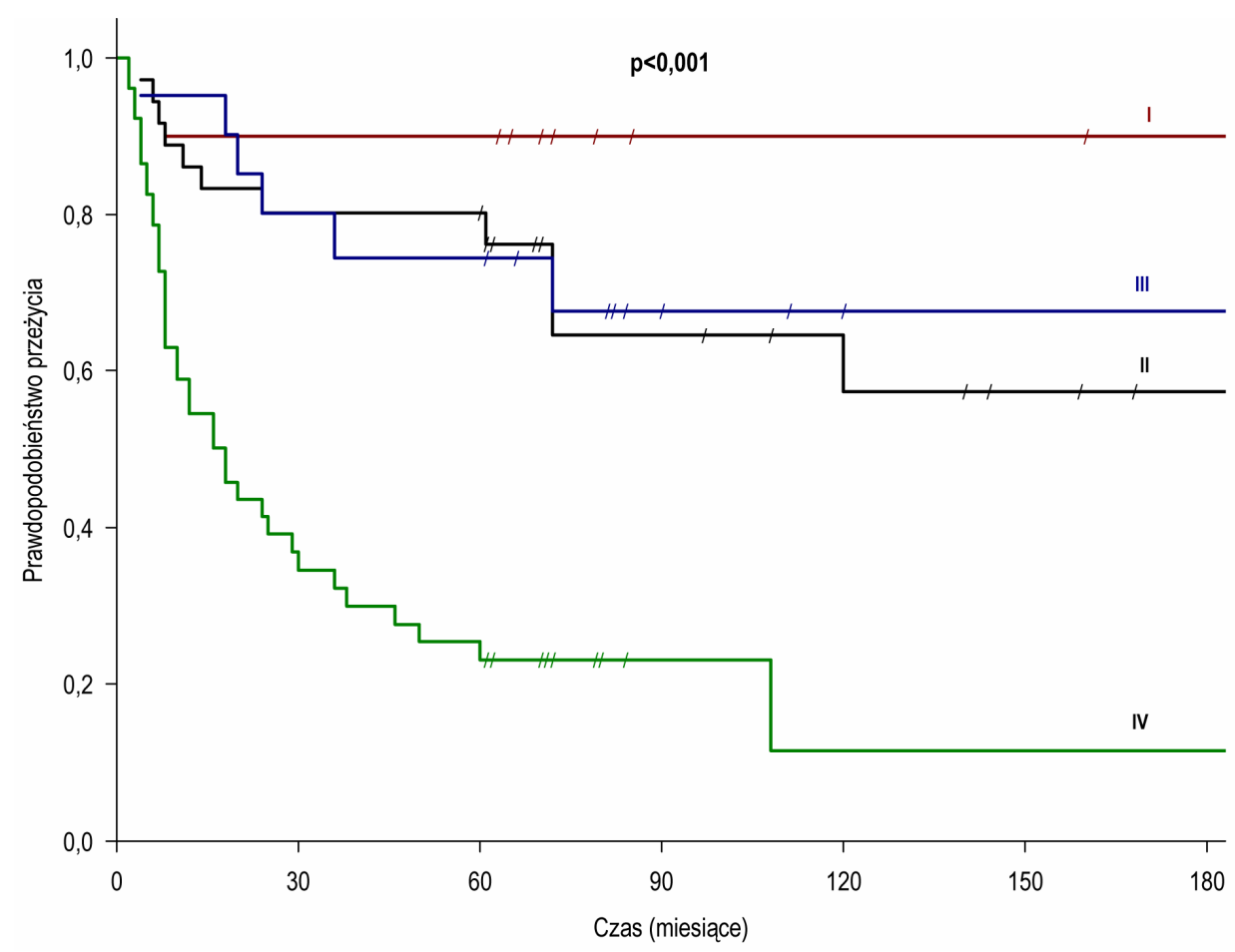

Ryc. 19. Wyniki leczenia w zależności od stopnia zaawansowania klinicznego

Stan marginesów mikroskopowych cięcia chirurgicznego również miał wpływ na wyniki leczenia. Przeżycie 5-letnie uzyskano u 45 na 79 chorych $(57,0 \%)$ z ujemnymi marginesami i u 9 spośród 30 pacjentów $(30,0 \%)$ z dodatnim lub wątpliwym marginesem. Szansa wyleczenia była 3,1 razy większa w grupie chorych, u których zabieg był mikroskopowo radykalny w porównaniu z grupa pacjentów z dodatnimi lub wątpliwymi marginesami cięcia chirurgicznego. Różnice pomiędzy odsetkami przeżyć w obu grupach są statystycznie znamienne. Wyniki leczenia w zależności od stanu marginesów mikroskopowych cięcia chirurgicznego przedstawiono w tabeli XXXIII i na rycinie 20. 
Tabela XXXIII

Wyniki leczenia w zależności od stanu marginesów mikroskopowych cięcia chirurgicznego

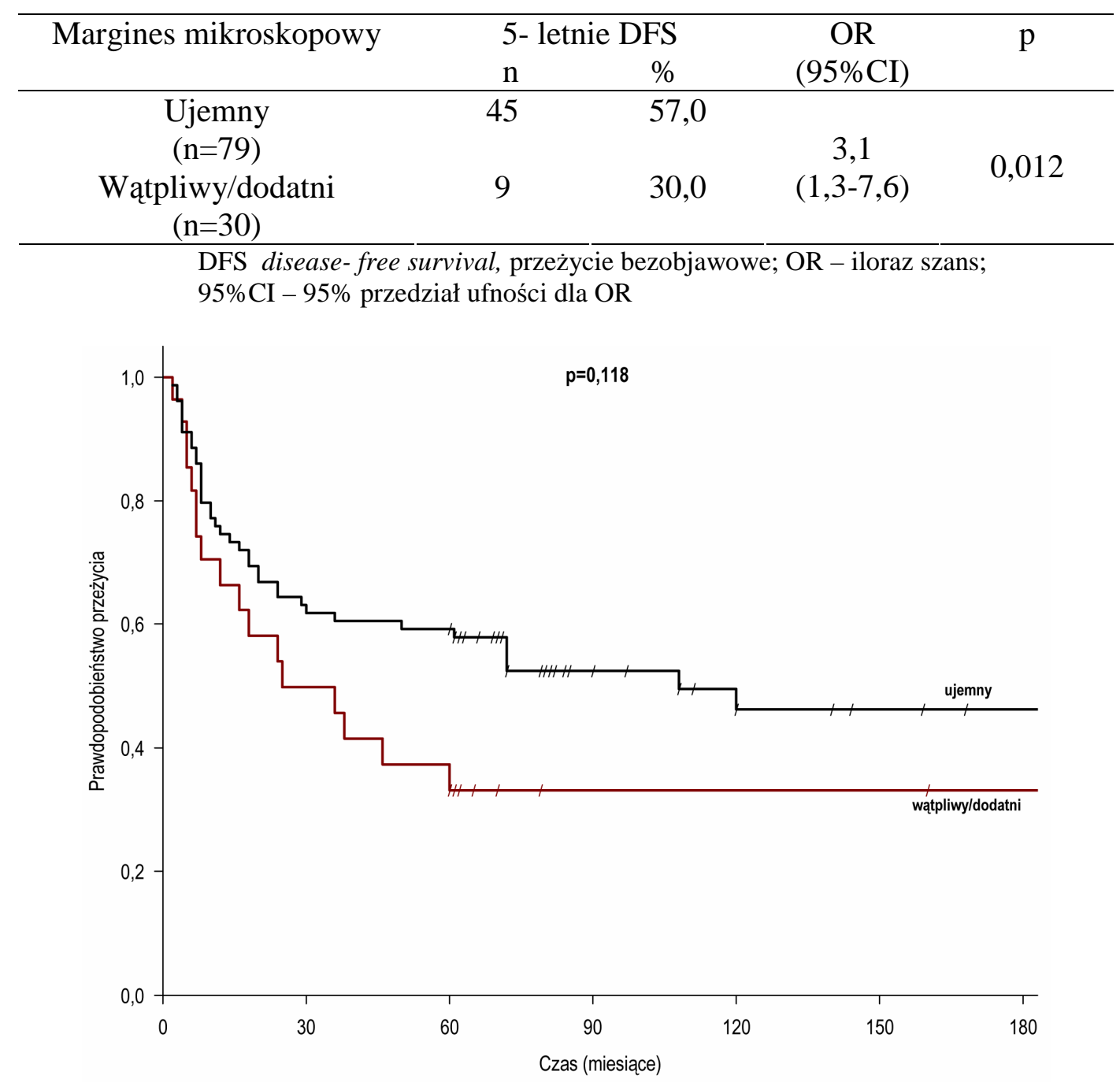

Ryc. 20. Wyniki leczenia w zależności od stanu marginesów mikroskopowych cięcia chirurgicznego

Również stopień złośliwości raków ślinianki przyusznej miał wpływ na wyniki leczenia, co ilustruje tabela XXXIV i rycina 21 . Większy odsetek wyleczeń uzyskano w grupie chorych z rakami o niskim/pośrednim stopniu złośliwości $(81,8 \%)$ w porównaniu z grupa z rakami o wysokim stopniu złośliwości - 35,5\%. Stopień złośliwości nowotworu znacząco wpływał na wyniki leczenia, gdyż szansa 5-letniego bezobjawowego przeżycia była 8,2 razy wyższa w grupie pacjentów 
z guzami o niskim lub pośrednim stopniu złośliwości w porównaniu z grupą chorych z rakami o wysokim stopniu złośliwości. Różnice pomiędzy odsetkami przeżyć w obu grupach są statystycznie znamienne.

Tabela XXXIV

Wyniki leczenia w zależności od stopnia złośliwości nowotworu

\begin{tabular}{ccccc}
\hline Stopień złośliwości & \multicolumn{2}{c}{ 5- letnie DFS } & OR & $\mathrm{p}$ \\
& $\mathrm{n}$ & $\%$ & $(95 \% \mathrm{CI})$ & \\
\hline $\begin{array}{c}\text { Niski/pośredni } \\
(\mathrm{n}=33)\end{array}$ & 27 & 81,8 & & \\
$\begin{array}{c}\text { Wysoki } \\
(\mathrm{n}=76)\end{array}$ & 27 & 35,5 & $(3,0-22,2)$ & 0,0001 \\
\hline
\end{tabular}

DFS disease- free survival, przeżycie bezobjawowe; OR - iloraz szans; 95\% CI - 95\% przedział ufności dla OR

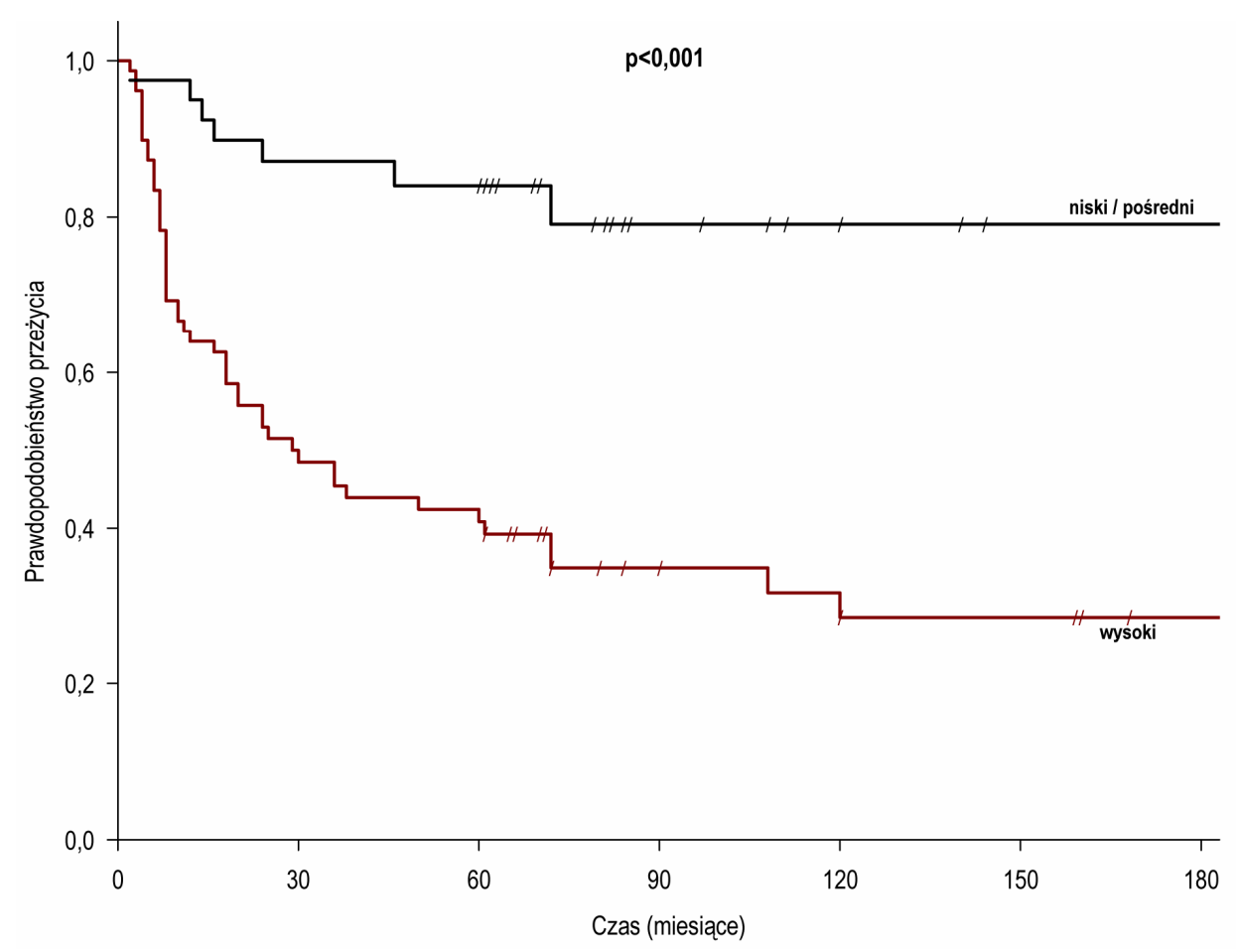

Ryc. 21. Wyniki leczenia w zależności od stopnia złośliwości nowotworu

Kolejnym analizowanym czynnikiem był wynik badania histologicznego usuniętych węzłów chłonnych śródśliniankowych i szyjnych (regionalnych). W tabeli XXXV i na rycinie 22 przedstawiono wyniki leczenia z uwzględnieniem przerzutów 
do śródśliniankowych, a w tabeli XXXVI i na rycinie 23 do szyjnych węzłów chłonnych. Przeżycie bezobjawowe uzyskano u 52 na 92 chorych $(56,5 \%)$ bez przerzutów i u 2 spośród 17 (11,8\%) z przerzutami do węzłów śródśliniankowych. Szansa wyleczenia była 9,8 razy większa w grupie chorych bez przerzutów w porównaniu z grupą chorych, u których stwierdzono przerzuty. Różnice pomiędzy odsetkami przeżyć w obu grupach są statystycznie znamienne.

Tabela XXXV

Wyniki leczenia z uwzględnieniem przerzutów do śródśliniankowych węzłów chłonnych

\begin{tabular}{ccccc}
\hline $\begin{array}{c}\text { Wézły chłonne } \\
\text { śódśliniankowe }\end{array}$ & \multicolumn{2}{c}{ 5- letnie DFS } & OR & $\mathrm{p}$ \\
\hline $\begin{array}{c}\text { Bez przerzutów } \\
(\mathrm{n}=92)\end{array}$ & 52 & 56,5 & & \\
$\begin{array}{c}\mathrm{Z} \text { przerzutami } \\
(\mathrm{n}=17)\end{array}$ & 2 & 11,8 & $(2,1-45,1)$ & 0,0007 \\
\hline
\end{tabular}

DFS disease-free survival, przeżycie bezobjawowe; OR - iloraz szans; 95\% CI - 95\% przedział ufności dla OR

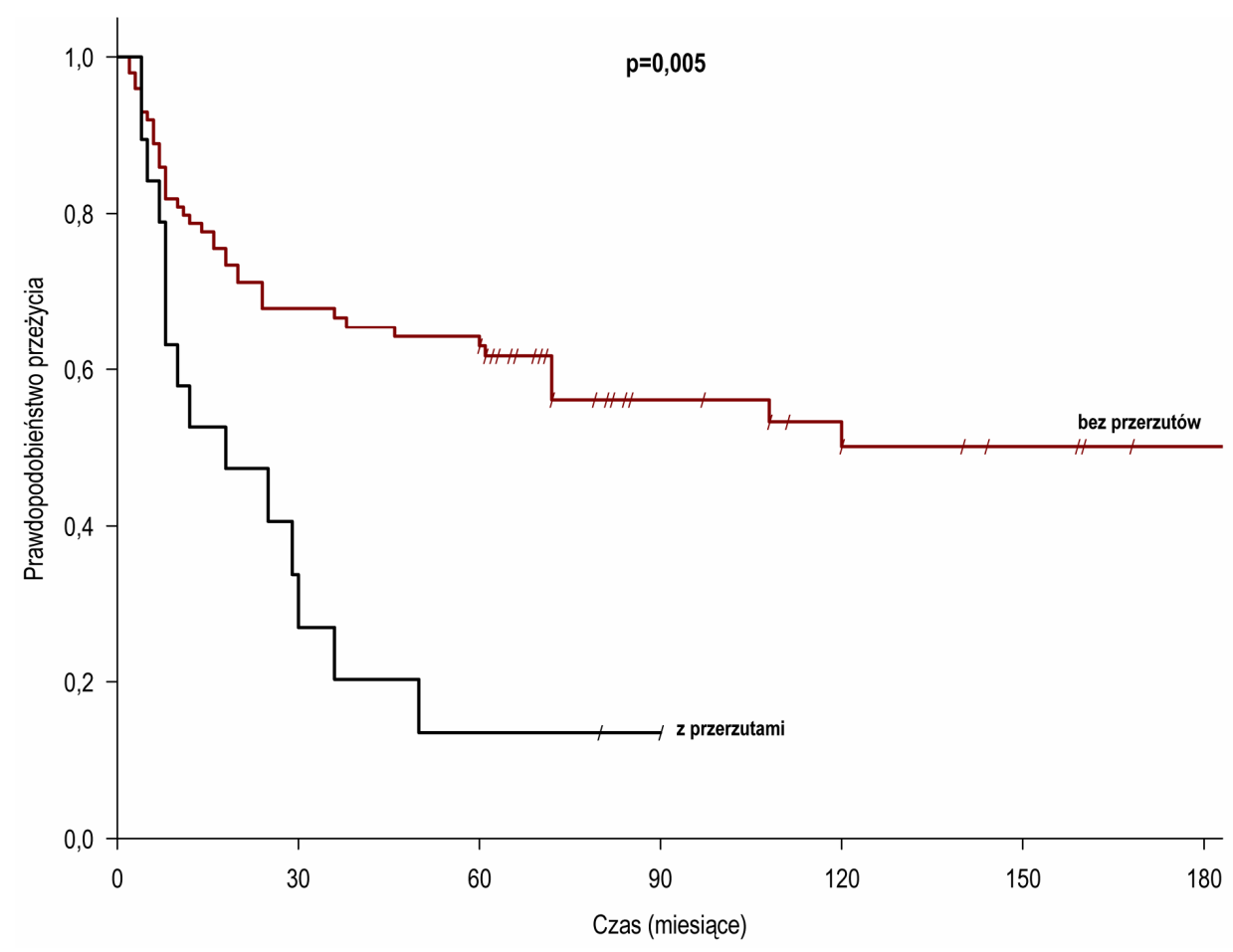

Ryc. 22. Wyniki leczenia z uwzględnieniem przerzutów do śródśliniankowych węzłów chłonnych 
W grupie pacjentów bez przerzutów do regionalnych węzłów chłonnych wyleczenie uzyskano u 33 spośród 54 (61,1\%), natomiast 5-letnie przeżycie uzyskano tylko u 7 na 37 chorych $(18,9 \%)$ z przerzutami. Szansa wyleczenia była 6,7 razy większa w grupie chorych bez przerzutów w porównaniu z grupą chorych, u których badanie histologiczne wykazało przerzuty. Różnice pomiędzy odsetkami przeżyć w obu grupach są statystycznie znamienne.

Tabela XXXVI

Wyniki leczenia z uwzględnieniem przerzutów do regionalnych węzłów chłonnych

\begin{tabular}{|c|c|c|c|c|}
\hline \multirow[t]{2}{*}{ Regionalne węzły chłonne } & \multicolumn{2}{|c|}{ 5- letnie DFS } & \multirow{2}{*}{$\begin{array}{c}\text { OR } \\
(95 \% \mathrm{CI})\end{array}$} & \multirow[t]{2}{*}{$\mathrm{p}$} \\
\hline & $\mathrm{n}$ & $\%$ & & \\
\hline $\begin{array}{l}\text { Bez przerzutów } \\
(\mathrm{n}=54)\end{array}$ & 33 & 61,1 & 6,7 & \\
\hline $\begin{array}{l}Z \text { przerzutami } \\
(\mathrm{n}=37)\end{array}$ & 7 & 18,9 & $(2,5-18,1)$ & 0,0007 \\
\hline
\end{tabular}

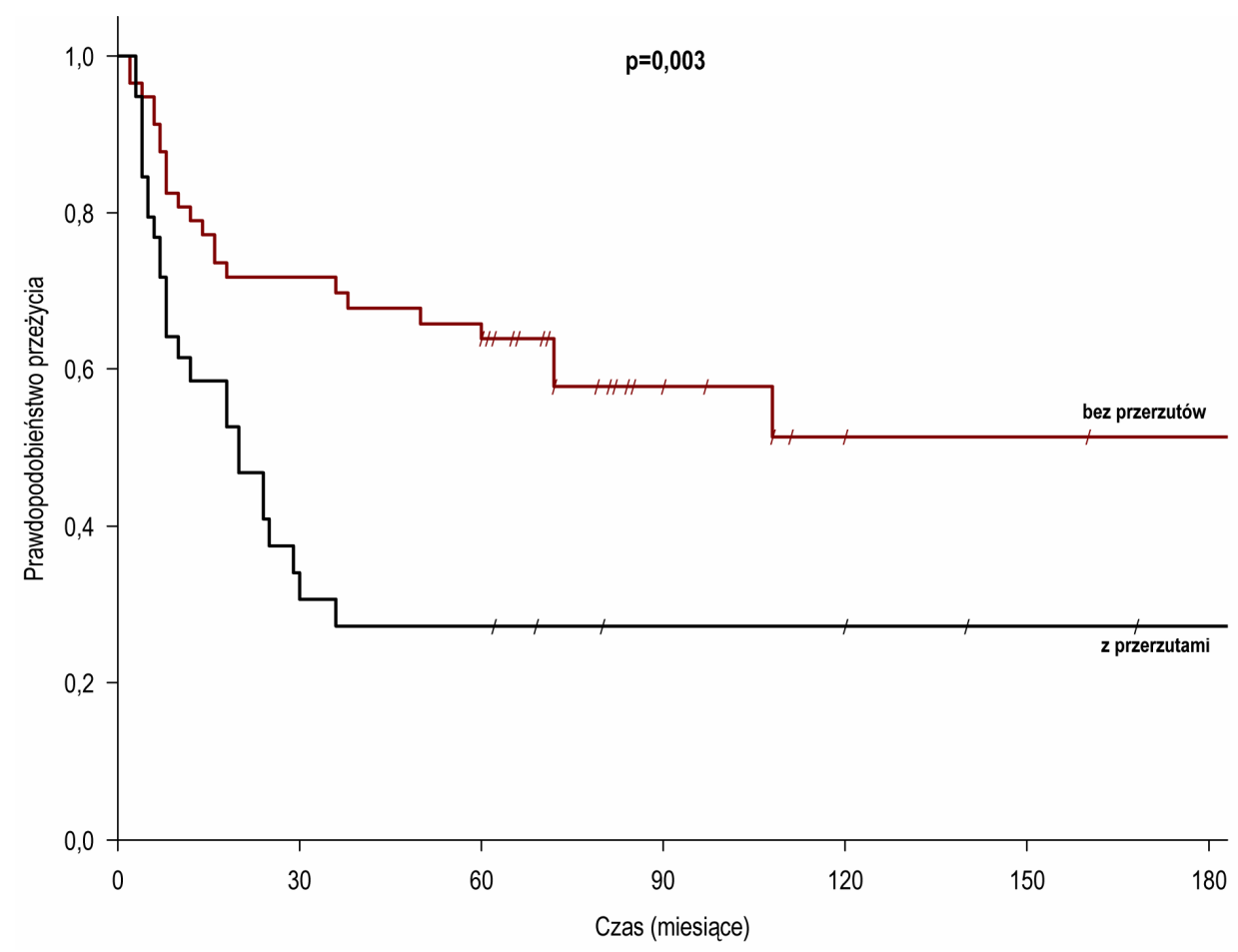

Ryc. 23. Wyniki leczenia z uwzględnieniem przerzutów do regionalnych węzłów chłonnych 
Dodatkowo w grupie chorych z czwartym stopniem zaawansowania narządowego zbadano wpływ naciekania nerwu twarzowego oraz naciekania skóry na 5-letnie przeżycie, co zostało przedstawione w tabelach XXXVII i XXXVIII oraz na rycinach 24 i 25 . Wyleczenie uzyskano u 5 na 20 chorych $(25,0 \%)$ z T4, ale bez nacieku nerwu twarzowego i u 4 spośród 28 (14,3\%) z jego naciekiem. Szansa wyleczenia choroby wydaje się być około 2 razy większa w grupie chorych z czwartym stopniem zaawansowania narządowego bez nacieku nerwu twarzowego w porównaniu z grupą chorych z T4 i naciekiem nerwu, jednakże różnice pomiędzy odsetkami przeżyć w obu grupach są statystycznie nieznamienne.

\section{Tabela XXXVII}

Wyniki leczenia w grupie chorych z czwartym stopniem zaawansowania narządowego z uwzględnieniem naciekania nerwu twarzowego

\begin{tabular}{|c|c|c|c|c|}
\hline \multirow{2}{*}{$\begin{array}{c}\text { Naciek nerwu VII } \\
\text { w zaawansowaniu T4 }\end{array}$} & \multicolumn{2}{|c|}{ 5- letnie DFS } & \multirow{2}{*}{$\begin{array}{c}\text { OR } \\
(95 \% \mathrm{CI})\end{array}$} & \multirow{2}{*}{$\mathrm{p}$} \\
\hline & $\mathrm{n}$ & $\%$ & & \\
\hline Nie & 5 & 25,0 & \multirow{3}{*}{$\begin{array}{c}2,0 \\
(0,5-8,7)\end{array}$} & \multirow{3}{*}{0,348} \\
\hline$(\mathrm{n}=20)$ & & & & \\
\hline $\begin{array}{c}\text { Tak } \\
(\mathrm{n}=28)\end{array}$ & 4 & 14,3 & & \\
\hline
\end{tabular}




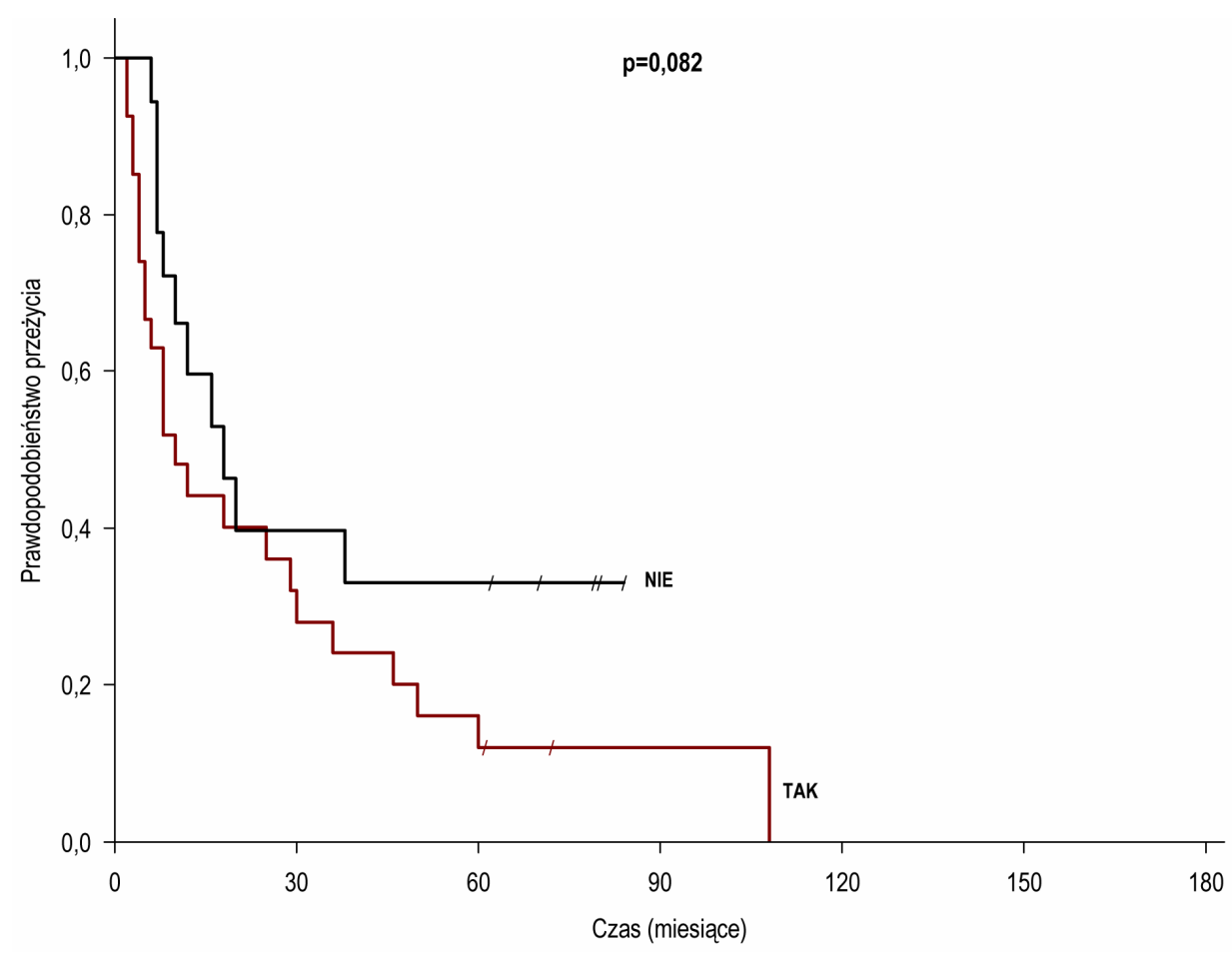

Ryc. 24. Wyniki leczenia w grupie chorych z czwartym stopniem zaawansowania narządowego z uwzględnieniem naciekania nerwu twarzowego

W grupie chorych z czwartym stopniem zaawansowania narządowego odsetek wyleczeń był wyższy u pacjentów z naciekaniem skóry (5/21 chorych, 23,8\%) w porównaniu z grupą bez jej zajęcia (4/27 pacjentów, 14,8\%). Szansa 5-letniego bezobjawowego przeżycia była porównywalna w obu grupach. Różnice pomiędzy odsetkami przeżyć w obu grupach są statystycznie nieznamienne.

Tabela XXXVIII

Wyniki leczenia w grupie chorych z czwartym stopniem zaawansowania narządowego z uwzględnieniem naciekania skóry

\begin{tabular}{ccccc}
\hline $\begin{array}{c}\text { Naciekanie skóry w } \\
\text { zaawansowaniu T4 }\end{array}$ & \multicolumn{2}{c}{ 5- letnie DFS } & $\begin{array}{c}\text { OR } \\
(95 \% \mathrm{CI})\end{array}$ & $\mathrm{p}$ \\
\hline $\begin{array}{c}\text { Nie } \\
(\mathrm{n}=27)\end{array}$ & 4 & 14,8 & & \\
$\begin{array}{c}\text { Tak } \\
(\mathrm{n}=21)\end{array}$ & 5 & 23,8 & $(0,2-4,6)$ & 0,428 \\
\hline
\end{tabular}

DFS disease-free survival, przeżycie bezobjawowe; OR - iloraz szans; 95\% CI - 95\% przedział ufności dla OR 


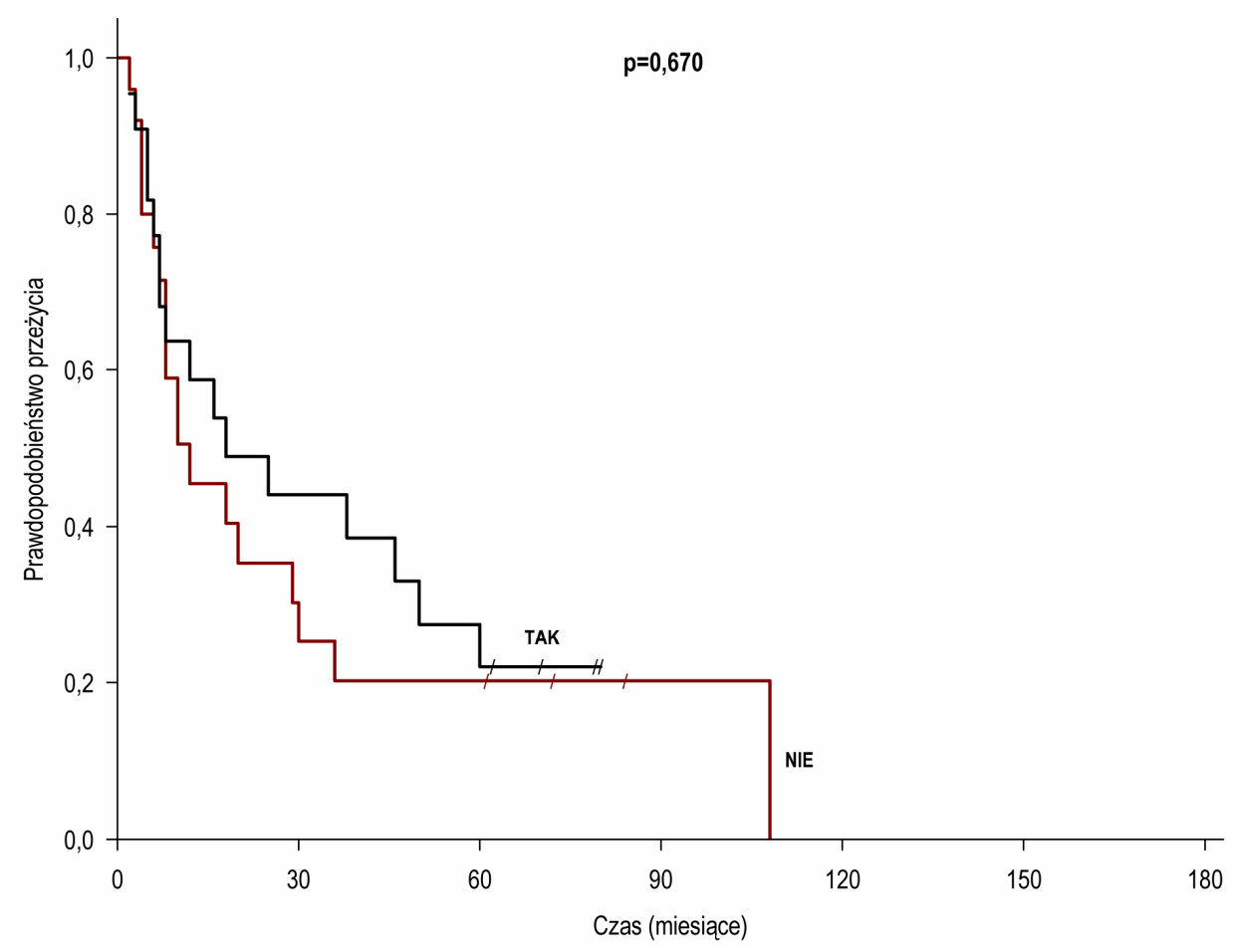

Ryc. 25. Wyniki leczenia w grupie chorych z czwartym stopniem zaawansowania narządowego z uwzględnieniem naciekania skóry

Celem poznania przydatności prognostycznej badanych parametrów wykonano analizę wieloczynnikową ich wpływu na 5-letnie bezobjawowe przeżycie (wyleczenie). W tabeli XXXIX przedstawiono związek między objawami i odchyleniami w badaniu klinicznym a wyleczeniem w analizie wieloczynnikowej. Niezależnymi czynnikami wpływającymi istotnie statystycznie na prawdopodobieństwo wyleczenia były zaburzenie czynności nerwu twarzowego i kliniczne cechy nacieku skóry. Występowanie niedowładu lub porażenia nerwu twarzowego zwiększa 4 krotnie ryzyko niepowodzenia leczenia, a kliniczne zajęcie skóry 3 krotnie. Pozostałe ocenianie czynniki okazały się nie być istotne statystycznie w ocenianym modelu wieloczynnikowym. 
Tabela XXXIX

Związek między objawami i odchyleniami w badaniu klinicznym a wyleczeniem w analizie wieloczynnikowej

\begin{tabular}{|c|c|c|c|c|c|}
\hline & Beta & HR & $-95 \% \mathrm{CI}$ & $+95 \% \mathrm{CI}$ & $\mathrm{p}$ \\
\hline $\begin{array}{l}\text { Zaburzenie czynności } \\
\text { nerwu VII }\end{array}$ & 1,39 & 4,01 & 2,20 & 7,32 & 0,00001 \\
\hline Naciek skóry & 1,09 & 2,99 & 1,56 & 5,70 & 0,0009 \\
\hline $\begin{array}{l}\text { Powiększone węzły } \\
\text { chłonne szyi }\end{array}$ & 0,45 & 1,57 & 0,90 & 2,74 & 0,114 \\
\hline Ból & 0,39 & 1,48 & 0,85 & 2,60 & 0,168 \\
\hline Brak ruchomości guza & 0,30 & 1,36 & 0,77 & 2,39 & 0,295 \\
\hline Szybki wzrost guza & $-0,27$ & 0,76 & 0,41 & 1,39 & 0,375 \\
\hline
\end{tabular}

W tabeli XL przedstawiono związek między naciekaniem poszczególnych struktur anatomicznych przez nowotwór a wyleczeniem w analizie wieloczynnikowej. Niezależnymi czynnikami wpływającymi istotnie statystycznie na prawdopodobieństwo 5-letniego bezobjawowego przeżycia były naciek żuchwy, nerwu twarzowego i skóry. Stwierdzenie nacieku żuchwy zwiększa 4,13 razy ryzyko niepowodzenia leczenia. Naciekanie nerwu twarzowego i skóry przez nowotwór zmniejsza szanse na wyleczenie odpowiednio 2,38 i 2,04 razy. Pozostałe oceniane czynniki okazały się nie być istotne statystycznie w ocenianym modelu wieloczynnikowym. 
Tabela XL

Związek między naciekaniem poszczególnych struktur anatomicznych przez nowotwór a wyleczeniem w analizie wieloczynnikowej

\begin{tabular}{lccccc}
\hline & Beta & HR & $-95 \%$ CI & $+95 \% \mathrm{CI}$ & $\mathrm{p}$ \\
\hline Naciek żuchwy & 1,42 & 4,13 & 1,22 & 13,92 & 0,022 \\
Naciek nerwu twarzowego & 0,87 & 2,38 & 1,38 & 4,11 & 0,002 \\
Naciek podstawy czaszki & 0,81 & 2,25 & 0,45 & 11,26 & 0,323 \\
Naciek skóry & 0,71 & 2,04 & 1,04 & 4,00 & 0,037 \\
$\begin{array}{l}\text { Naciek przestrzeni } \\
\text { przygardłowej }\end{array}$ & 0,56 & 1,76 & 0,86 & 3,57 & 0,120 \\
Naciek mięśnia żwacza & 0,42 & 1,52 & 0,80 & 2,89 & 0,202 \\
$\begin{array}{l}\text { Naciek przewodu } \\
\text { słuchowego zewn. }\end{array}$ & 0,06 & 1,06 & 0,40 & 2,79 & 0,909 \\
\hline \multicolumn{1}{l}{ Beta- współczynnik regresji. HR - iloraz szans. 95CI - 95\% przedział ufności dla HR. }
\end{tabular}

W tabeli XLI przedstawiono związek między parametrami zależnymi od nowotworu a wyleczeniem $\mathrm{w}$ analizie wieloczynnikowej. Zaawansowanie narządowe i stopień złośliwości guza były niezależnymi czynnikami wpływającymi istotnie statystycznie na wyleczenie. Każdy kolejny stopień zaawansowanie narządowego zwiększał ryzyko niepowodzenia leczenia blisko dwukrotnie $(1,78)$, natomiast wysoki stopień złośliwości nowotworu zwiększał je 1,5 razy. Zaawansowanie regionalne nie wpływało w sposób istotny statystycznie w ocenianym modelu wieloczynnikowym na wyleczenie.

Tabela XLI

Związek między parametrami zależnymi do nowotworu a wyleczeniem w analizie wieloczynnikowej

\begin{tabular}{lccccc}
\hline & Beta & HR & $-95 \%$ CI & $+95 \%$ CI & $\mathrm{p}$ \\
\hline $\begin{array}{l}\text { Zaawansowanie } \\
\text { narządowe }\end{array}$ & 0,58 & 1,78 & 1,29 & 2,45 & 0,0005 \\
$\begin{array}{l}\text { Zaawansowanie } \\
\text { regionalne }\end{array}$ & 0,39 & 1,48 & 0,84 & 2,61 & 0,170 \\
$\begin{array}{l}\text { Stopień złośliwości } \\
\text { ne,38 }\end{array}$ & 1,47 & 1,12 & 1,92 & 0,006 \\
\hline
\end{tabular}

Beta- współczynnik regresji. HR - iloraz szans. 95CI - 95\% przedział ufności dla HR 
W tabeli XLII przedstawiono związek między wybranymi parametrami kliniczno-patologicznymi a wyleczeniem w analizie wieloczynnikowej. Niezależnymi czynnikami wpływającymi istotnie statystycznie na prawdopodobieństwo wyleczenia były wiek, zaawansowanie kliniczne oraz przerzuty do węzłów chłonnych szyi. Ryzyko niepowodzenia leczenia wzrastało o liczbę kolejnych lat życia (1,02 na każdy rok). Kolejny wyższy stopień zaawansowanie klinicznego zwiększał ryzyko nawrotu choroby 1,82 razy, natomiast obecność przerzutów do węzłów chłonnych szyi podwyższała je 2,29 razy. Pozostałe ocenianie czynniki okazały się nie być istotne statystycznie w ocenianym modelu wieloczynnikowym.

Tabela XLII

Związek między wybranymi parametrami kliniczno-patologicznymi a wyleczeniem w analizie wieloczynnikowej

\begin{tabular}{lccccc}
\hline & Beta & HR & $-95 \% \mathrm{CI}$ & $+95 \% \mathrm{CI}$ & $\mathrm{p}$ \\
\hline Wiek & 0,02 & 1,02 & 1,00 & 1,04 & 0,018 \\
Płeć & 0,46 & 1,58 & 0,90 & 2,79 & 0,114 \\
$\begin{array}{l}\text { Zaawansowanie } \\
\text { kliniczne }\end{array}$ & 0,60 & 1,82 & 1,26 & 2,62 & 0,001 \\
$\begin{array}{l}\text { Przerzuty do węzłów } \\
\text { chłonnych szyi }\end{array}$ & 0,83 & 2,29 & 1,26 & 4,14 & 0,006 \\
$\begin{array}{l}\text { Margines mikroskopowy } \\
\text { Beta- współczynnik regresji. HR - iloraz szans. 95CI - 95\% przedział ufności dla HR }\end{array}$ & 0,06 & 1,06 & 0,83 & 1,55 & 0,747 \\
\end{tabular}




\subsection{Niepowodzenie leczenia}

Wśród niepowodzeń leczenia wyodrębniono wznowę miejscową, przerzuty do regionalnych węzłów chłonnych (tzw. wznowa węzłowa) oraz przerzuty odległe. U części chorych doszło do wznowy wieloogniskowej, a więc jednoczasowego wystapienia wznowy miejscowej i/lub węzłowej i/lub przerzutu odległego. Spośród 109 chorych z co najmniej 5 letnim okresem obserwacji, nawrót choroby obserwowano u 55 (50,5\%). Wznowa miejscowa wystapiła u 18 chorych (16,5\%). U 16 pacjentów $(14,7 \%)$ w toku obserwacji ujawniły się przerzuty odległe, bez cech nawrotu miejscowego lub węzłowego. W kolejnych 17 przypadkach nawrót choroby miał charakter wieloogniskowy (wznowa miejscowo-węzłowa - 5, wznowa miejscowa i przerzut odległy - 4, wznowa węzłowa i przerzut odległy - 3, wznowa miejscowo-węzłowa i przerzut odległy - 5). Izolowana wznowa węzłowa wystapiła jedynie u 4 chorych (3,7\%). Rodzaje niepowodzenia leczenia zostały przedstawione w tabeli XLII. Rycina 26 obrazuje rodzaje i współwystępowanie nawrotów choroby nowotworowej.

Tabela XLII

Rodzaj niepowodzenia leczenia

\begin{tabular}{lcc}
\hline Rodzaj niepowodzenia leczenia & $\mathrm{n}$ & $\%$ \\
\hline Wznowa miejscowa & 18 & 16,5 \\
Wznowa węzłowa & 4 & 3,7 \\
Przerzuty odległe & 16 & 14,7 \\
Wznowa wieloogniskowa & 17 & 15,6 \\
\hline Łącznie & 55 & 50,5 \\
\hline
\end{tabular}




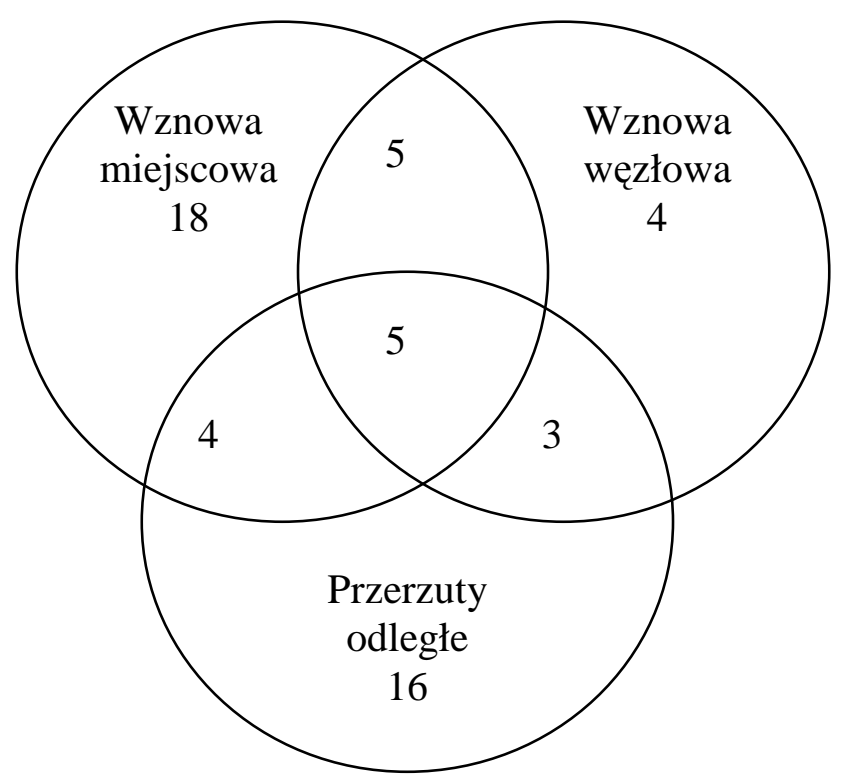

Ryc. 26. Rodzaje i współwystępowanie nawrotów choroby nowotworowej

Przerzuty odległe w liczbie 34 ujawniły się u 28 chorych. Najczęściej były to przerzuty do płuc, następnie kości, wątroby, mózgu, pozaregionalnych węzłów chłonnych oraz u jednego chorego do skóry. Lokalizację przerzutów odległych przedstawia tabela XLIII.

Tabela XLIII

Lokalizacja przerzutów odległych

\begin{tabular}{ll}
\hline Lokalizacja & $\mathrm{n}$ \\
\hline Płuca & 17 \\
Kości* & 6 \\
Wątroba & 4 \\
Mózg & 3 \\
Węzły chłonne (pozaregionalne)** & 3 \\
Skóra & 1 \\
\hline Razem & $34 * * *$ \\
\hline \multicolumn{1}{c}{$*$ czaszka, kręosłup, żebra, miednica } & \\
$\quad * *$ śódpiersiowe, pachowe & \\
$\quad * *$ 34 lokalizacje u 28 chorych &
\end{tabular}

Większość, bo 45 (81,8\%) nawrotów wystąpiła w ciągu pierwszych 3 lat obserwacji. Rycina 27 przedstawia liczbę chorych z nawrotami choroby w kolejnych latach obserwacji. Czas wystapienia wznowy miejscowej wahał się od 2 do 108 miesięcy 
(średnio 21,8), regionalnej - od 6 do 88 miesięcy (średnio 23,7). Przerzuty odległe były stwierdzane od 2 do 84 miesięcy (średnio 22,8) od zakończenia pierwotnego leczenia.

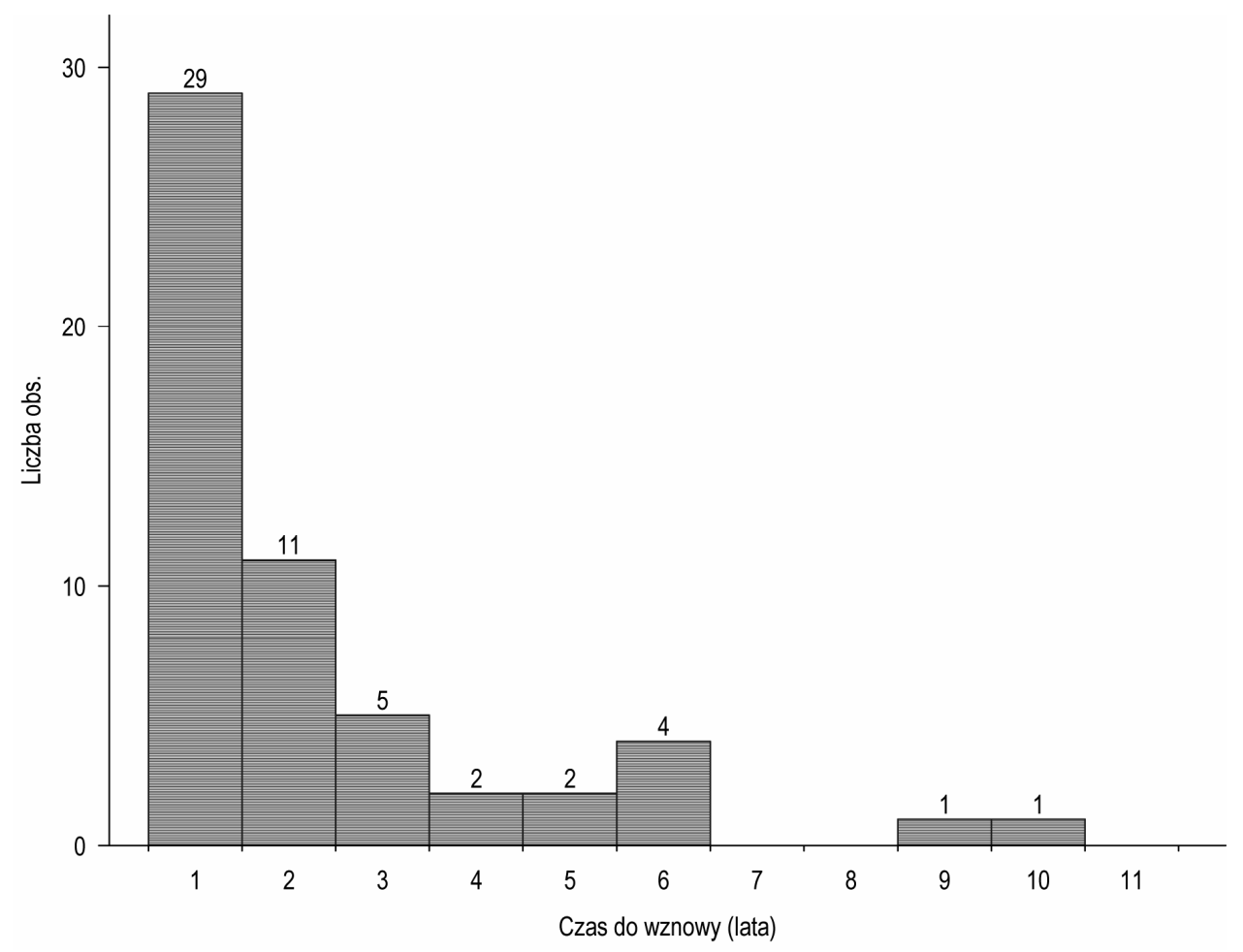

Ryc. 27. Liczba chorych z nawrotami nowotworu w kolejnych latach obserwacji

Liczba chorych, u których wystąpił nawrót choroby nowotworowej była zróżnicowana w zależności od zaawansowania klinicznego, stopnia złośliwości i utkania histologicznego raka ślinianki, co zostało przedstawione w tabeli XLIV. Największy odsetek nawrotów miejscowych obserwowano w IV i II stopniu zaawansowania klinicznego - $23(44,2 \%)$ i $8(26,7 \%)$, a także u chorych z nowotworami o utkaniu gruczolakoraka bliżej nieokreślonego - 11 (50,0\%).

Wyraźna różnica między częstością wznów miejscowych i przerzutów odległych występuje również między grupą raków o wysokim w porównaniu z rakami o pośrednim/niskim stopniu złośliwości. Odsetek chorych z przerzutami odległymi 
wzrasta wraz ze stopniem zaawansowania klinicznego. Przerzuty odległe najczęściej występowały w złośliwym gruczolaku wielopostaciowym (42,8\%), a zdecydowanie rzadziej w raku śluzowo-naskórkowym $(10,0 \%)$. Natomiast nie zaobserwowano tak wyraźnych różnic w liczbie wznów węzłowych w zależności od zaawansowania klinicznego (z wyjątkiem stopnia I) oraz od stopnia złośliwości. Wznowa regionalna najrzadziej występowała u pacjentów z gruczolakorakiem bliżej nieokreślonym.

Tabela XLIV

Rodzaj niepowodzenia leczenia w zależności od zaawansowania klinicznego, stopnia złośliwości i utkania histologicznego

\begin{tabular}{|c|c|c|c|c|c|c|c|}
\hline & \multirow[b]{2}{*}{$\mathrm{n}$} & \multicolumn{2}{|c|}{$\begin{array}{l}\text { Wznowa } \\
\text { miejscowa }\end{array}$} & \multicolumn{2}{|c|}{$\begin{array}{l}\text { Wznowa } \\
\text { węzłowa }\end{array}$} & \multicolumn{2}{|c|}{$\begin{array}{c}\text { Przerzuty } \\
\text { odległe }\end{array}$} \\
\hline & & $\mathrm{n}$ & $\%$ & $\mathrm{n}$ & $\%$ & $\mathrm{n}$ & $\%$ \\
\hline Całość & 109 & 32 & 29,3 & 17 & 15,6 & 28 & 25,7 \\
\hline \multicolumn{8}{|l|}{ Zaawansowanie kliniczne } \\
\hline I & 9 & 0 & & 1 & & 1 & \\
\hline II & 30 & 8 & 26,7 & 5 & 16,7 & 5 & 16,7 \\
\hline III & 18 & 1 & 5,5 & 3 & 16,7 & 4 & 22,2 \\
\hline IV & 52 & 23 & 44,2 & 8 & 15,4 & 18 & 34,6 \\
\hline \multicolumn{8}{|l|}{ Stopień złośliwości } \\
\hline Wysoki & 76 & 27 & 35,5 & 13 & 17,1 & 27 & 35,5 \\
\hline Pośredni/niski & 33 & 5 & 15,1 & 4 & 12,1 & 1 & 3,0 \\
\hline \multicolumn{8}{|l|}{ Utkanie histologiczne } \\
\hline Gruczolakorak BNO & 22 & 11 & 50,0 & 2 & 9,1 & 6 & 27,3 \\
\hline RwGW & 21 & 5 & 23,8 & 4 & 19,0 & 9 & 42,8 \\
\hline Rak śluzowo-naskórkowy & 20 & 5 & 25,0 & 4 & 20,0 & 2 & 10,0 \\
\hline Rak gruczołowo-torbielowaty & 18 & 5 & 27,8 & 3 & 16,7 & 5 & 27,8 \\
\hline Rak zrazikowokomórkowy & 8 & 1 & & 2 & & 1 & \\
\hline Rak niezróżnicowany & 8 & 2 & & 1 & & 3 & \\
\hline Rak płaskonabłonkowy & 6 & 2 & & 0 & & 1 & \\
\hline Inne & 6 & 1 & & 1 & & 1 & \\
\hline
\end{tabular}

W 22 przypadkach wznowy miejscowej i 16 wznowy węzłowej podjęto leczenie, którego rodzaje przedstawia tabela XLV. 10 nawrotów miejscowych 
i 12 regionalnych leczono wyłącznie chirurgicznie lub metodą skojarzoną (z radiolub chemioterapia). W pozostałych przypadkach stosowano radioterapię, radiochemioterapię lub paliatywną chemioterapię. Leczenie chirurgiczne nawrotu miejscowego i regionalnego zależało od zakresu przebytej pierwotnej operacji. U chorych po parotidektomii częściowej zachowawczej polegało ono na wycięciu guza wraz z pozostałością ślinianki przyusznej i gałęziami nerwu twarzowego w przypadku jego naciekania. W leczeniu chirurgicznym wznów miejscowych po radykalnych, całkowitych parotidektomiach stosowano miejscowe wycięcie nowotworu w marginesie tkanek otaczających (skóra, mięśnie, żuchwa). Reoperacje węzłowe polegały na selektywnym wycięciu węzłów przerzutowych, często ze strukturami nielimfatycznymi, takimi jak żyła szyjna wewnętrzna, mięsień mostkowoobojczykowo-sutkowy, nerw dodatkowy, nerw podjęzykowy (o ile zachowano je w trakcie pierwotnego leczenia).

Tabela XLV

Sposób leczenia wznowy węzłowej i miejscowej

\begin{tabular}{|c|c|c|c|c|c|c|c|c|}
\hline \multirow{3}{*}{$\begin{array}{l}\text { Rodzaj } \\
\text { wznowy }\end{array}$} & \multirow{3}{*}{ Chir } & \multicolumn{6}{|c|}{ Sposób leczenia } & \multirow[t]{3}{*}{ Razem } \\
\hline & & Chir & Chir & RT & ChRT & ChT & Bez & \\
\hline & & RT & ChT & & & & (brak zgody) & \\
\hline Miejscowa & 4 & 5 & 1 & 4 & 1 & 7 & $10(3)$ & 32 \\
\hline Węzłowa & 5 & 5 & 2 & 0 & 1 & 3 & 1 & 17 \\
\hline
\end{tabular}




\section{OMÓWIENIE}

\subsection{Dane kliniczno-patologiczne}

Wiek chorych w naszym materiale wahał się od 11 do 90 lat. Według danych z piśmiennictwa światowego najmłodszy chory leczony z powodu raka ślinianki przyusznej miał 4 [50], a najstarszy 100 lat [109]. Najniższą średnią wieku chorych wynoszącą 49 lat przedstawił Lima i wsp., natomiast najwyższą Olejniczak i wsp.67,7 lat [55, 73]. W większości prac średnia wieku pacjentów wynosi około 60 lat, co jest wartością zbliżoną do średniej wieku chorych w naszym materiale - 58 lat $[16,34,39,43,48,80,81,86,114,124] . \mathrm{W}$ analizowanym materiale przeważali chorzy między 51 a 80 rokiem życia ze szczytem zachorowań w 7 (kobiety) i 6 (mężczyźni) dekadzie życia, podobna struktura wieku występowała w materiale przedstawionym przez Pietniczkę-Załęską i wsp. oraz Wittena i wsp. [79, 120], natomiast u Leversteina i wsp. większość stanowili chorzy w 8 dekadzie życia [54]. Chorzy poniżej 20 roku życia stanowili w naszym materiale tylko 2,3\%. Również w pracy Wahlberga i wsp. jedynie 2,0\% pacjentów było w wieku poniżej 19 lat, co potwierdza stosunkową rzadkość pierwotnych raków ślinianki przyusznej w tej grupie wiekowej [116]. Na uwagę zasługuje materiał Shapiro i wsp. przedstawiający 85 pierwotnych raków ślinianki przyusznej u chorych poniżej 18 roku życia (średnia wieku około13 lat) [93].

W analizowanej grupie było 53,4\% kobiet i 46,6\% mężczyzn, stosunek kobiet do mężczyzn wynosił 1,1:1. Odwrotna tendencja płci występuje w wynikach opublikowanych przez innych autorów, w których przeważają mężczyźni [34, 43, 50, 54, $55,77,80,81,86,109,112,114,120,124]$, od $51 \%$ u Tullio i wsp. do 59\% w materiale Wittena i wsp. [114, 120], gdzie stosunek kobiet do mężczyzn wynosił 
1:1,4. W kilku zestawieniach występuje również przewaga kobiet $[16,39,48,75$, 79], jednak jest ona mniejsza niż w naszym materiale, a odsetek kobiet wynosi $51 \%$ u Carrillo i wsp. oraz 52\% u Huanga i wsp. [16, 48]. Przewagę kobiet w naszym materiale można wytłumaczyć między innymi tym, iż większy odsetek mężczyzn niż kobiet został zdyskwalifikowany z leczenie operacyjnego z powodu zaawansowania nowotworu i chorób współistniejących.

W większości prac dane dotyczące objawów i odchyleń w badaniu chorych z rakiem ślinianki przyusznej nie zostały szczegółowo scharakteryzowane. W pracy omawiającej objawy nowotworów ślinianki przyusznej Wong wyszczególnił te, które budziły podejrzenie procesu złośliwego. Do objawów złośliwości zaliczył powiększenie węzłów chłonnych szyi, niedowład lub porażenie nerwu twarzowego, naciek i owrzodzenie skóry, ból, szybki wzrost guza, jego unieruchomienie i znaczną twardość [121].

W naszym materiale obecność guza ślinianki przyusznej stwierdzono u 96,9\% chorych, co jest zgodne z wynikami innych autorów (od 80\% do 100\%) $[16,39,50,77,80,85,86,112,120]$. W materiale przedstawionym przez Leversteina i wsp. oraz przez Kelleya i wsp. guz ślinianki przyusznej bez innych współistniejących objawów stwierdzono odpowiednio u 49\% i 74\% chorych [50, 54]. Jednakże najwyższa liczba chorych z guzem bez towarzyszących innych objawów występowała w materiale Huanga i wsp. oraz Theriaulta i wsp. - odpowiednio $78 \%$ i $83 \%$ pacjentów [48, 112]. Ponadto Godballe i wsp. podają, że u 9\% chorych guz ślinianki przyusznej został stwierdzony przypadkowo w trakcie ogólnego badania fizykalnego lub w badaniach obrazowych wykonywanych z innych powodów [39]. W naszym materiale guz był jedynym objawem tylko u 20,6\% pacjentów, co świadczy o zdecydowanie wyższym zaawansowaniu klinicznym u naszych chorych. Należy tutaj pod- 
kreślić, że rak ślinianki przyusznej może manifestować się wyłącznie jako wolno rosnący guz, a brak objawów wskazujących na jego złośliwy charakter może odwlekać rozpoczęcie leczenia. Istotne jest również to, że w naszym materiale u 2,3\% chorych guz miał charakter nawrotu miejscowego (złośliwego) po uprzednio usuniętym gruczolaku wielopostaciowym. Kolejnymi ważnymi objawami związanymi z guzem były dynamika jego wzrostu oraz ruchomość względem podłoża. Szybkie powiększanie się guza podawało 46,5\% leczonych przez nas pacjentów. Unieruchomienie guza stwierdzono u kolejnych 33,6\%, w piśmiennictwie opisywano je u $18 \%$ do $50 \%$ pacjentów $[80,85]$.

Ból był drugim pod względem częstości objawem i występował u 40,4\% pacjentów. $\mathrm{W}$ innych pracach liczba chorych $\mathrm{z}$ dolegliwościami bólowymi waha się od $7 \%$ do $59 \%[11,16,39,43,48,50,77,79,80,85,109,120,124]$. Rafla podaje dodatkowo, że u $6 \%$ chorych występowała otalgia, a w materiale Pohara i wsp. u 3\% pacjentów ból głowy [80, 85]. Inni autorzy nie wyszczególniają charakteru bólu. W naszym materiale u 7,6\% chorych ból manifestował się jako otalgia, co jest wartością zbliżoną do danych przedstawionych przez Rafla [85].

Powiększone węzły chłonne szyi stwierdzono u 32,0\% chorych, z czego u ponad połowy z nich w postaci pojedynczego węzła mniejszego niż $3 \mathrm{~cm}$. Odsetek chorych $\mathrm{z}$ powiększonymi węzłami chłonnymi waha się $\mathrm{w}$ piśmiennictwie od 15,5\% do $34,2 \%[11,39,54,77,86,109,112,124]$.

Kolejnym częstym objawem było zaburzenie czynności nerwu twarzowego, które występowało u 20,6\% chorych. Odsetek pacjentów z niedowładem lub porażeniem nerwu twarzowego według zestawień polskich i światowych jest bardzo zróżnicowany $[11,16,34,39,43,48,50,55,77,80,85,86,109,120,124]$, od $7,4 \%$ w materiale przedstawionym przez Kelleya i wsp. do $40 \%$ w pracy Pietniczki-Załęskiej 
i wsp. [50, 79]. Zwraca uwagę fakt, że w materiale 85 chorych w wieku poniżej 18 roku życia przedstawionym przez Shapiro i wsp, tylko u jednego $(1,1 \%)$ wystapił niedowład nerwu twarzowego [93]. W naszym materiale całkowite porażenie nerwu twarzowego obserwowano u 7,6\% chorych, co jest wartością zbliżoną do wyników przedstawionych przez Terhaarda i wsp. (7\%), ale znacznie mniejszą niż w pracy Godballe`a i wsp. - 14\% [39, 109]. W pracy Leversteina i wsp. zaburzenie czynności nerwu twarzowego wystapiło u $25 \%$ chorych, z czego połowę stanowili pacjenci z gruczolakorakiem bliżej nieokreślonym [54]. Terhaard i wsp. zbadali czynniki wpływające na przedoperacyjną funkcję nerwu twarzowego. W analizie wieloczynnikowej wykazali zależność między czynnością nerwu twarzowego przed leczeniem chirurgicznym a wiekiem, naciekiem skóry, zaawansowaniem regionalnym oraz lokalizacją w płacie głębokim ślinianki. Natomiast nie zaobserwowali związku między płcią chorych, utkaniem histologicznym raka, czasem trwania objawów oraz obecnością nacieku kości [109]. Naciek skóry występował w naszym materiale u 19,8\% chorych (owrzodzenie stwierdzono u 6,1\%), wartości te mieszczą się w zakresie występującym w piśmiennictwie - od $9,4 \%$ do $28 \%$ chorych (owrzodzenie $3 \%$ do 9,44\%) $[11,16,34,80,85,109]$. Zaburzenia czucia pod postacią parastezji podawało 9,9\% chorych. Inne rzadsze objawy i odchylenia w badaniu występujące w naszym materiale to szczękościsk (3,8\%), asymetria gardła (3\%), nacieczenie ujścia lub krwawienie z przewodu wyprowadzającego ślinianki (1,5\%) oraz porażenie nerwu językowo-gardłowego (1,5\%). Z wyżej wymienionych odchyleń jedynie w materiale przedstawionym przez Pohara i wsp. u 7\% chorych występowało porażenie nerwu IX [80].

Według Wonga, ryzyko procesu złośliwego wzrasta proporcjonalnie do liczby objawów złośliwości i wynosi od około $20 \%$ u pacjentów bez tych objawów do 
$100 \%$ u chorych z 4 takimi objawami [121]. Jednakże w naszym materiale 20,6\% chorych nie prezentowało żadnego, a kolejne $25,9 \%$ wyłącznie jeden objaw złośliwości; wyniki te potwierdzają konieczność zachowania ostrożności w klinicznym różnicowaniu między zmianami łagodnymi i złośliwymi ślinianki przyusznej. McGuirt i wsp. określili trafność badania klinicznego w rozpoznawaniu złośliwego charakteru guza ślinianki przyusznej na 85\% [61].

W naszym materiale występowały wyraźne różnice w liczbie objawów wskazujących na złośliwy charakter nowotworu z uwzględnieniem stopnia jego złośliwości. W grupie chorych z rakami o wysokim stopniu złośliwości w porównaniu z pacjentami z nowotworami o pośredniej lub niskiej złośliwości częściej występował ból (odpowiednio 47,1\% i 26,1\%), upośledzenie funkcji nerwu twarzowego (28,0\% vs $4,7 \%)$, powiększenie węzłów chłonnych $(34,8 \%$ vs $26,1 \%)$, a także zajęcie skóry (21,3\% vs $16,6 \%$, w tym owrzodzenie w 7,8\% vs $2,3 \%)$, jak również parastezje okolicy guza i/lub policzka - 14,2\% vs $7,8 \%$ chorych. W pracy Zbärena i wsp. znaleziono podobne porównanie. Wykazali oni wyraźne różnice w występowaniu niedowładu lub porażenia nerwu twarzowego oraz powiększonych węzłów chłonnych u chorych z rakami o wysokim stopniu złośliwości w porównaniu z pacjentami z nowotworami o niskim stopniu złośliwości (odpowiednio $22 \%$ vs $10 \%$ oraz $28 \%$ vs $14 \%$ ), natomiast nie stwierdzili różnić w występowaniu dolegliwości bólowych między tymi grupami [124].

Czas trwania objawów przedstawiany w literaturze polskiej i światowej jest bardzo zróżnicowany - od 1 do 480 miesięcy [11, 54, 86, 120]. W materiale Wittena i wsp. u $45 \%$ chorych objawy trwały ponad 6 miesięcy, u kolejnych $10 \%$ od roku do 2 lat, a u 15,0\% ponad 5 lat [120]. Również Leverstein i wsp. podają, że u 21,5\% leczonych przez nich chorych czas trwania objawów wynosił ponad 12 miesięcy 
[54]. Długi wywiad w rakach ślinianki przyusznej można wytłumaczyć powolnym wzrostem nowotworów o niskim stopniu złośliwości lub zezłośliwieniem wieloletniego gruczolaka wielopostaciowego. W pracy Bienia i wsp. czas objawów wahał się od 2 do 48 miesięcy (średnio 16 miesięcy), natomiast w materiale przedstawionym przez Leversteina i wsp. wynosił 36 miesięcy $[11,54]$. W naszym materiale średni czas trwania objawów przed zgłoszeniem się chorego do lekarza wynosił 51,3 miesięcy, ale w przypadku objawów sugerujących proces złośliwy - 4 miesiące. Po wyłączeniu grupy chorych $\mathrm{z}$ rakiem $\mathrm{w}$ gruczolaku wielopostaciowym (z wywiadem średnio 140 miesięcznym) średni czas trwania objawów wynosił 25,4 miesiące, co jest wartością zbliżoną do podawanych przez innych autorów [11, 54, 86, 120].

W ciagu 30 lat, z których pochodzi nasz materiał nastapił bardzo znaczny postęp w zakresie technik obrazowania - od sialografii, poprzez ultrasonografię do tomografii komputerowej i tomografii metodą rezonansu magnetycznego. Sialografię wykonano u 19 chorych, jedynie u jednego z nich wykazała cechy złośliwości guza (5,3\% wyników prawdziwie dodatnich). Obecnie jest to metoda o znaczeniu historycznym. Badanie USG wykonano u 61,8\% chorych, uzyskując informacje odnośnie wielkości guza, jego struktury wewnętrznej i ograniczenia oraz stanu regionalnych węzłów chłonnych. Złośliwy charakter nowotworu na podstawie obrazu USG rozpoznano u 46,9\% chorych. Odsetek ten jest porównywalny z wynikami innych autorów. Kopeć i wsp. określili czułość badania ultrasonograficznego w wykrywaniu złośliwego charakteru guza na 52\% [52]. Czułość badania USG w publikacji Bozzato i wsp. wynosiła 46,2\% [13]. Burduk i wsp. podkreślają wysoką wartość tego badania w diagnostyce różnicowej nowotworów ślinianek, a Yonetsu i wsp. wykazali 81\% trafność USG w różnicowaniu między gruczolakiem wielopostaciowym a rakiem $[13,122]$. Nowoczesne metody obrazowania TK i MR wykonano u odpowiednio 
$22,1 \%$ i $6,9 \%$ chorych. Pozwoliły one na bardziej precyzyjną ocenę rozległości procesu nowotworowego i potwierdzenie jego złośliwego charakteru. Radiologiczne cechy złośliwości guzów ślinianki przyusznej stwierdzono w badaniach TK i MR odpowiednio w 79,3\% i 77,7\% przypadków. Niektórzy autorzy uważają, że badanie TK ma wartość przede wszystkim w ocenie umiejscowienia i rozległości nowotworu przy niskiej czułości w różnicowaniu ich charakteru $[9,51]$. Według Berga i wsp., przy użyciu tomografii komputerowej możliwe jest wykrywanie zmian wieloogniskowych, ocena położenia guza względem żyły zażuchwowej i pośrednio nerwu VII oraz stanu regionalnych węzłów chłonnych [9]. Wyniki pracy McGuirta i wsp. były podobne do obserwacji własnych, gdyż na podstawie badania TK lub MR u 84\% chorych z rakiem stwierdzili jego złośliwy charakter [61]. Tak wysoką czułość tych badań można wytłumaczyć tym, iż u większości chorych wykonywano je w nowotworach o dużym stopniu zaawansowania i/lub klinicznym podejrzeniem ich złośliwego charakteru. Som i wsp. dowiedli, iż badanie metodą MR wykazuje większą czułość niż TK w wykrywaniu raka w gruczolaku wielopostaciowym, zwłaszcza przy ujemnym wyniku BAC [97]. Natomiast Goto i wsp. wykazali zdecydowaną wyższość badania MR nad USG w ocenie umiejscowienia guza (wewnątrz lub zewnątrz ślinianki), a także w określeniu jego kształtu i ograniczenia [40]. Badanie pozytonowej tomografii emisyjnej (PET), które jest najbardziej zaawansowaną technologicznie metodą diagnostyczną (nie było wykonywane u naszych chorych), wykazuje, według danych z piśmiennictwa czułość od $75 \%$ do $100 \%$ w wykrywaniu złośliwego charakteru nowotworu ślinianki przyusznej. Jednakże przy niskiej specyficzności (20\% do 43\% wyników fałszywie dodatnich) i bardzo wysokich kosztach ma one bardzo ograniczone zastosowanie w diagnostyce guzów gruczołów ślinowych $[61,115]$. 
Przedoperacyjną diagnostykę w postaci biopsji aspiracyjnej cienkoigłowej (BAC) wykonano u 67,9\% chorych. Na jej podstawie rozpoznano złośliwy charakter nowotworu u $56,2 \%$ chorych - wynik prawdziwie dodatni, natomiast brak nowotworu lub nowotwór łagodny (wynik fałszywie ujemny) u 39,3\% pacjentów. W 4,5\% przypadków BAC była niediagnostyczna. Pełną zgodność rozpoznania cytologicznego z histopatologicznym uzyskano tylko u 14,6\% chorych. Podobne wyniki przedstawili Tullio i wsp., Zurrida i wsp. oraz Lin i wsp. - odpowiednio 57\%, 61\% i 63\% wyników prawdziwie dodatnich $[56,114,125]$. Jednakże odsetek wyników fałszywie ujemnych BAC w pracach dwóch ostatnich autorów był znacznie mniejszy (25\% i $18,5 \%)$, przy bardzo wysokiej liczbie biopsji niediagnostycznych $(13,9 \%$ i $18,5 \%)$ $[56,114,125]$. Odsetek wyników prawdziwie dodatnich BAC w pracach polskich autorów wahał się od $70 \%$ do $75 \%$ [11, 79]. Na podstawie wyników przedstawionych w literaturze światowej BAC cechuje się czułością od 74\% do 85\% [1, 20, 61, 117, 123]. Pełna zgodność rozpoznania cytologicznego z histopatologicznym w pracy Zbärena i wsp. wynosiła 35\%, a w materiale Berga i wsp. - 50\% [9, 123]. Niezadowalające wyniku BAC w naszym materiale można wytłumaczyć faktem, że była ona wykonywana przeważnie poza naszym ośrodkiem, przez patologów nie mających należytego doświadczenia w ocenie cytologicznej guzów gruczołów ślinowych oraz rozwojem techniki BAC w ciągu ostatnich 30 lat, z których pochodzi nasz materiał kliniczny. Zgodzić się należy ze stwierdzeniem Berga i wsp., że BAC ma największe znaczenie w odróżnieniu zmian zapalnych od nowotworowych (szczególnie w przypadku szybkiego powiększania się guza i dolegliwości bólowych), w planowaniu zakresu leczenia i uzyskaniu na nie zgody pacjenta (resekcja nerwu twarzowego, operacja węzłowa), a także u chorych z przeciwwskazaniami ogólnymi i dużym ryzykiem powikłań zabiegu [9]. 
Śródoperacyjne badanie histologiczne wykonano u 50,4\% chorych. Złośliwy charakter nowotworu stwierdzono u 84,8\% z nich, jednakże pełną zgodność z ostatecznym rozpoznaniem histopatologicznym w trybie zwykłym uzyskano tylko w 30,3\%. Nieco gorsze wyniki przedstawili Lin i wsp. (77,8\% prawdziwie dodatnich) [56]. W pracy Zbärena i wsp. czułość badania doraźnego wynosiła 93\% (przy 95\% specyficzności), w ich materiale bardzo wysoka była również zgodność wyniku badania śródoperacyjnego z rozpoznaniem w trybie zwykłym - 72\% [123]. Idealne rezultaty przedstawili Arabi Mianroodi i wsp., w ich materiale czułość i specyficzność badania śródoperacyjnego wynosiły 100\% [1].

Uważa się, że celem badania śródoperacyjnego jest potwierdzenie lub wykluczenie złośliwego charakteru nowotworu, co pozwala uniknąć niedostatecznego lub nadmiernego leczenia (under- $i$ overtreatment) oraz określenie radykalności zabiegu (marginesy chirurgiczne). Pełna zgodność wyniku tego badania z ostatecznym rozpoznaniem histologicznym ma marginalne znacznie, jednakże bardzo pożądane jest określenie stopnia złośliwości raka.

W naszym materiale dominował wysoki stopień zaawansowania narządowego i niski regionalnego. Stopień T3 i T4 stwierdzono łącznie u 58,0\%, a N0 u 67,9\% chorych. W piśmiennictwie odsetek chorych z poszczególnymi stopniami zaawansowania miejscowego jest bardzo zróżnicowany, natomiast, podobnie jak w niniejszym zestawieniu, zdecydowanie dominowali pacjenci bez powiększonych węzłów chłonnych (N0), którzy stanowili od 60,6\% do 83,0\% [16, 39, 77, 109, 112, 120]. W naszym materiale odsetek chorych ze stopniem N1 i N2 wynosił odpowiednio $16,8 \%$ i $15,3 \%$, nie było natomiast pacjentów z trzecim stopniem zaawansowania regionalnego. Podobna tendencję zauważa się w piśmiennictwie, gdzie odsetek pacjentów z N3 jest bardzo mały (od 0 do 5,5\%) [16, 39, 77, 86]. Natomiast zwraca 
uwagę większa liczba chorych z zaawansowaniem N2 niż z N1 [16, 39, 77, 109]. Brak powiększonych węzłów chłonnych, nawet przy wysokim zaawansowaniu narządowym, wydaje się być cechą charakterystyczną raków ślinianki przyusznej. Jednakże wskazane jest wykonanie USG i/ lub TK celem potwierdzenie ujemnego wyniku badania klinicznego węzłów chłonnych.

Wysoki (III i IV) stopień zaawansowania klinicznego stwierdzono łącznie u 64,1\% naszych chorych, co jest wartością zbliżoną do danych przedstawionych przez Pietniczkę-Załęską i wsp. (67,7\%) [79]. Natomiast u innych autorów przeważali chorzy z I i II stopniem zaawansowania klinicznego (od 52,4\% do 74\%) [34, 39, $54,55,77,80,114]$.

Drugi nowotwór złośliwy występował u $16,5 \%$ chorych podczas co najmniej 5 letniego okresu obserwacji. U 22,2\% z nich miał charakter synchroniczny. Dominowały raki skóry głowy (m.in. nos, małżowina uszna) o utkaniu podstawnokomórkowym lub płaskonabłonkowym, jednakże tylko u jednego chorego drugie ognisko pierwotne rozwinęło się w obrębie narządów głowy i szyi (tarczyca). Pozostałe lokalizacje to płuca, żołądek, jelito grube, gruczoł krokowy oraz nerka. Dwaj pacjenci zmarli z powodu drugiego nowotworu, w tym chory, u którego dwa niezależne ogniska gruczolakoraka rozwinęły się po 20 i 26 latach od zakończenia leczeniu raka ślinianki przyusznej. W materiale Wittena i wsp. drugi pierwotny nowotwór złośliwy występował u 12,3\% chorych leczonych z powodu raka ślinianki przyusznej. Podobnie jak u naszych pacjentów, dominowały nowotwory złośliwe skóry (rak podstawnokomórkowy, czerniak złośliwy) i tylko u jednego chorego drugie ognisko pierwotne zlokalizowane było w obrębie narządów głowy i szyi (krtań) [120].

W analizowanej grupie rozpoznano na podstawie badania histologicznego materiału operacyjnego 14 różnych typów histologicznych. Gruczolakorak bliżej 
nieokreślony, rak w gruczolaku wielopostaciowym i rak śluzowo-naskórkowy występowały najczęściej, odpowiednio $19,0 \%, 19,0 \%$ i 18,3\%. Nieco rzadziej rozpoznawano raka gruczołowo-torbielowatego - 14,5\%. Rak zrazikowokomórkowy, niezróżnicowany i płaskonabłonkowy występowały u odpowiednio 8,4\%, 6,9\%, 5,3\% chorych. Pozostałe siedem podtypów raków rozpoznano łącznie u 8,4\% pacjentów, były to rak przewodowy ślinianek, rak nabłonkowo-mioepitelialny i torbielakogruczolak oraz po jednym przypadku gruczolakoraka podstawnokomórkowego, raka jasnokomórkowego bliżej nieokreślonego, gruczolakoraka śluzowego i raka łojowego. Odsetek chorych z poszczególnymi typami raków ślinianki przyusznej według danych z literatury polskiej i światowej jest bardzo zróżnicowany. Podobnie jak w analizowanym materiale dominują cztery typy - rak śluzowo-naskórkowy, gruczolakorak bliżej nieokreślony, rak gruczołowo-torbielowaty oraz rak w gruczolaku wielopostaciowym $[16,34,39,43,48,54,55,75,77,79,80,81,85,86,109,112,114$, 116, 120, 124]. Występowanie raka śluzowo-naskórkowego wahało się od 4,4\% w materiale Rafla do 34,6\% w pracy Carrillo i wsp. [16, 85]. Najniższy odsetek chorych z gruczolakorakiem bliżej nieokreślonym przedstawił Pedersen i wsp. - 10,0\%, najwyższy Rafla (40,3\%) [77, 85]. Rak w gruczolaku wielopostaciowym stanowił od 4,0\% w materiale Carrillo i wsp. oraz Tullio i wsp. do 29,0\% u Harbo i wsp. [16, 43, 114]. Występowanie raka gruczołowo-torbielowatego wahało się od 8,9\% (Rafla) do 20,2\% w materiale Gallo i wsp. [34, 85]. Rak zrazikowokomórkowy stanowił od 7\% (Wittem i wsp.) do $27 \%$ (Godballe i wsp.) [39, 120]. Odsetek chorych z rakiem niezróżnicowanym był najniższy w materiale Godballe`a i wsp.- 1\%, a najwyższy w pracy Rafla $(19,4 \%)$ [39, 85]. Rak płaskonabłonkowy występował od 0,8\% w zestawieniu Limy i wsp. do 16,9\% w materiale Gallo i wsp. [34, 55]. Częstość występowania raka przewodowego ślinianek wahała się od 1\% (Pohar i wsp.) do 9\% (Tul- 
lio i wsp.) [80, 114]. Inne typu histologiczne raków występowały od $2 \%$ do $12 \%$ chorych [75, 109]. Odsetek wszystkich typów histologicznych w naszym materiale mieścił się w zakresie średnich wartości przedstawionych w literaturze. Tak szeroki zakres występowania poszczególnych typów histologicznych raków ślinianki przyusznej można wytłumaczyć zmiennością geograficzną, ale przede wszystkim trudnościami w postawieniu precyzyjnego rozpoznania zgodnego ze zmieniającą się klasyfikacją histologiczną tych nowotworów. Niektórzy autorzy podkreślają potrzebę rewizji rozpoznania histologicznego. W materiale Godballe`a i wsp., po ponownej ocenie preparatów histologicznych dokonanej przez dwóch niezależnych patologów, 12\% guzów okazało się być zmianami przerzutowymi do ślinianki przyusznej, a w kolejnych $12 \%$ zmieniono rozpoznanie na inny podtyp raka [39]. W pracy Poortena i wsp. po ponownym przejrzeniu preparatów histologicznych rozpoznanie zmieniono aż w 25\% [81]. Wysoki odsetek chorych z rakiem płaskonabłonkowym, rakiem niezróżnicowanym oraz gruczolakorakiem bliżej nieokreślonym w pracach niektórych autorów można wytłumaczyć przerzutowym charakterem tych nowotworów.

W literaturze polskiej i światowej występuje podział na dwa (wysoki i niski) lub trzy (wysoki, pośredni, niski) stopnie złośliwości, co więcej, te same typy nowotworów w różnych pracach zaliczane są do odmiennych stopni złośliwości. W naszym materiale dominowały zdecydowanie raki o wysokim stopniu złośliwości 67,9\%, raki o pośrednim i niskim stopniu złośliwości stwierdzono odpowiednio u 6,1\% i 25,9\% chorych. Odsetek chorych z wysokim stopniem złośliwości, według danych z piśmiennictwa, waha się od $41 \%$ do $72,7 \%$ [34, 80, 114, 124].

Podobnie jak w naszym materiale częstość występowania raków zaliczanych do pośredniego stopnia złośliwości jest w piśmiennictwie niska, od 10\% (Lima 
i wsp.) do $18 \%$ (w pracy Pedersena i wsp.) [55, 77]. Przewaga raków o wysokim stopniu złośliwości (a więc najbardziej agresywnych klinicznie) w naszym materiale miała znaczny wpływ na obraz całej analizowanej grupy chorych. W tym podtypie częściej występowały objawy złośliwości, guzy te miały zazwyczaj wyższe zaawansowanie kliniczne, a więc częściej zachodziła konieczność bardziej radykalnego leczenia, co z kolei wpływało na gorsze jego wyniki.

Przerzuty do węzłów chłonnych szyi stwierdzono u 41,6\% naszych pacjentów, u których wykonano operację węzłową. Według danych z piśmiennictwa, odsetek chorych z przerzutami do węzłów chłonnych w przebiegu raka ślinianki przyusznej waha się od 9\% w materiale Tullio i wsp. do 53\% w pracy Stennerta i wsp. [34, $43,55,77,80,85,86,104,109,114,120,124]$.

Przerzuty w węzłach N0 stwierdzono w naszym materiale w 30,3\% przypadków, natomiast w pracach innych autorów stwierdzano je u 9\% do 48\% chorych [3, 34, 50, 55, 86, 104, 120, 124]. Przerzuty w węzłach N1 i N2 występowały odpowiednio u 54,5\% i 65,0\% leczonych przez nas chorych. Według danych z piśmiennictwa, odsetek chorych z przerzutami węzłowymi przy zaawansowaniu regionalnym N1 - N3 wahał się od 16\% w materiale Armstronga i wsp. do $100 \%$ w opracowaniu Kelleya i wsp. [3, 50]. Gallo i wsp. określili w swojej pracy bardziej szczegółowo częstość występowania przerzutów węzłowych - 71,4\% w stopniu N1 i 100\% w zaawansowaniu N2 [34]. Wysoki odsetek przerzutów węzłowych, zwłaszcza utajonych, w naszym materiale był zgodny z wynikami przedstawianymi przez większość autorów.

W analizowanym materiale przerzuty węzłowe najczęściej występowały w raku śluzowo-naskórkowym, gruczolakoraku (bliżej nieokreślonym) oraz raku w gruczolaku wielopostaciowym - odpowiednio 52,4\%, 50,0\% i 47,4\%. Przerzuty 
węzłowe w czwartym co do częstości raku gruczołowo-torbielowatym stwierdzono tylko u 14,3\% chorych. W rzadszych nowotworach przerzuty do węzłów chłonnych występowały u 2 spośród 3 chorych z rakiem przewodowym ślinianek, odpowiednio w 3 z 8 i 2 z 6 przypadków raka niezróżnicowanego i płaskonabłonkowego oraz u 2 z 8 pacjentów z rakiem zrazikowokomórkowym. Według danych z piśmiennictwa, przerzuty do węzłów chłonnych występowały najczęściej w gruczolakoraku bliżej nieokreślonym (od 22\% do 50\%), raku niezróżnicowanym (od 21\% do 64\%) oraz raku płaskonabłonkowym (od $20 \%$ do $68 \%$ ) $[3,7,43,54,85,86,104,112$, 120]. Wielu autorów podaje również wysoki odsetek przerzutów węzłowych u chorych z rakiem śluzowo-naskórkowym [2, 7, 43, 86], chociaż w materiale Theriaulta i wsp. występowały one tylko w 9\% przypadków [112]. Ponadto Regis de Brito Santos i wsp. na podstawie własnego materiału zwracają uwagę na bardzo wysokie ryzyko przerzutów węzłowych u pacjentów z rakiem przewodowym ślinianek [86]. Przerzuty węzłowe w raku w gruczolaku wielopostaciowym wahały się od 5\% w materiale Theriault i wsp. do $25 \% \mathrm{w}$ pracy Wittena i wsp. $[112,120]$. W pracach Stengerta i wsp. oraz Theriaulta i wsp. najniższy odsetek chorych z przerzutami do węzłów chłonnych występował w rakach gruczołowo-torbielowatym i zrazikowokomórkowym $[104,112]$. Odsetek przerzutów węzłowych w poszczególnych typach histologicznych raka ślinianki przyusznej u leczonym przez nas chorych mieścił się, z wyjątkiem raka w gruczolaku wielopostaciowym, w zakresie podawanym w piśmiennictwie. Wysoką częstość przerzutów do węzłów chłonnych u naszych chorych z tym rakiem można wytłumaczyć wysokim stopniem złośliwości komponenty złośliwej gruczolaka wielopostaciowego i zaawansowaniem miejscowym w zdecydowanej większości przypadków. 
Odsetek chorych z przerzutami do węzłów chłonnych różnił się w naszym materiale w zależności od stopnia złośliwości. W nowotworach o wysokim stopniu złośliwości przerzuty węzłowe stwierdzono u 50,6\% chorych (z czego u 34,8\% utajone), natomiast w grupie pacjentów z rakami o pośrednim i niskim stopniu złośliwości występowały one u 19,3\% pacjentów (w tym u 20\% z N0). Wyniki własne są zgodne z przedstawianymi przez innych autorów: w materiale Armstronga i wsp. przerzuty węzłowe występowały u $49 \%$ chorych $\mathrm{z}$ rakami o wysokim stopniu oraz u $16 \%$ chorych z rakami o niskim lub pośrednim stopniu złośliwości [3]. W materiale Zbärena i wsp. odsetek chorych z przerzutami węzłowymi był również zróżnicowany w zależności od stopnia złośliwości raka. U pacjentów z rakami o wysokim stopniu złośliwości oraz $\mathrm{w}$ grupie $\mathrm{z}$ nowotworami o niskim lub pośrednim stopniu złośliwości wynosił on odpowiednio 36\% vs 15\% (zaawansowanie N1-N3) oraz $37 \%$ vs $10 \%$ w N0 [124]. W naszym materiale odsetek chorych z przerzutami do węzłów chłonnych był wyraźnie zróżnicowany w zależności od stopnia zaawansowania narządowego i wahał się od $14,3 \%$ w T1 do 50,9\% w stopniu T4. W materiale Armstronga i wsp. częstość przerzutów węzłowych w zależności od cechy $\mathrm{T}$ wynosiła od $7 \%$ w T1 do $24 \%$ w T4, natomiast w pracy Stennerta i wsp. przerzuty stwierdzono aż u 29\% chorych w stopniu T1, u 54\% w T2, a w T3 i T4 odpowiednio u $65 \%$ i $54 \%$ pacjentów $[3,104]$. W niniejszym zestawieniu najwięcej utajonych przerzutów węzłowych stwierdzono w stopniu T2 - 34,8\% oraz w T4 (34,5\%), w zaawansowaniu T3 ich częstość była mniejsza (22,2\%), natomiast w T1 nie występowały. W pracy Regis de Brito Santosa i wsp. nie zaobserwowano podobnej tendencji, gdyż 76,5\% utajonych przerzutów węzłowych stwierdzono w zaawansowaniu narządowym T3 lub T4 [86]. Według danych z piśmiennictwa, ryzyko przerzutów węzłowych w raku ślinianki przyusznej zależy od stopnia jego złośliwości, utkania 
histologicznego, zaawansowania narządowego (wielkości guza, czynności nerwu twarzowego oraz obecności naciekania pozagruczołowego) [3, 10, 104]. Regis de Brito Santos i wsp. stwierdzili ponadto, że desmoplazja, martwica i naciekanie okołonerwowe również zwiększają częstość przerzutów do węzłów chłonnych [86]. Obserwacje własne i innych autorów potwierdzają konieczność wykonywania operacji węzłowych (elektywnych i terapeutycznych) w raku ślinianki przyusznej, zwłaszcza w przypadku wysokiego zaawansowania narządowego, wysokiego stopnia złośliwości oraz utkania histologicznego związanego z dużym ryzykiem przerzutów węzłowych, gdy uzyskano takie informacje na podstawie BAC i/lub badania śródoperacyjnego.

\subsection{Sposób leczenia}

W naszym materiale 44,3\% chorych było leczonych wyłącznie chirurgicznie, a u 55,7\% zastosowano uzupełniające napromieniania. Parotidektomię zachowawczą wykonano u 42,7\% chorych, półzachowawczą u 16,0\% pacjentów, a radykalną u 41,2\%. Odsetek chorych, u których z powodu raka wykonano operację całkowicie oszczędzającą nerw twarzowy waha się w piśmiennictwie od $56 \%$ do $70 \%$, ponadto część autorów wyróżnia również parotidektomię półzachowawczą - od 5\% do $28 \%$ [16, 34, 50, 114]. Wyższy odsetek zabiegów radykalnych w naszym materiale związany jest z faktem, że u 58,0\% chorych stwierdzono trzeci i czwarty stopień zaawansowania narządowego. Istotne jest również to, że w latach 80-tych dominowały parotidektomie radykalne, natomiast po 1990 roku zaczęły przeważać operacje zachowawcze, co jest zgodne z tendencją wykonywania zabiegów oszczędzających nerw twarzowy w przeciągu ostatnich 30 lat. Obecnie uważa się, że parotidektomię rady- 
kalną należy wykonywać wyłącznie w przypadkach przedoperacyjnego porażenia lub stwierdzonego śródoperacyjnie naciekania tego nerwu [54, cyt. wg 82].

U 82,4\% pacjentów wycięcie ślinianki uzupełniono operacją węzłową na szyi, z czego u 50,3\% był to zabieg elektywny. Według danych z piśmiennictwa, operacje węzłowe wykonywano u 26,7\% do 48,2\% chorych [16, 34, 50, 86, 114]. Natomiast odsetek chorych poddanych uzupełniającym napromienianiom wahał się do 33,1\% do $78,4 \%[34,50,54,86,114]$.

Najczęstszym powikłaniem leczenia operacyjnego było zaburzenie czynności nerwu twarzowego, które wystąpiło u 58,4\% chorych, z czego u 7,8\% miało charakter trwały. Porażenie nerwu twarzowego w następstwie parotidektomii radykalnej nie zostało zaliczone w niniejszej pracy do powikłań. Przejściowy niedowład nerwu twarzowego stwierdzono u wszystkich chorych po całkowitym usunięciu miąższu ślinianki i u 21,9\% pacjentów po parotidektomi częściowej. Przemijające zaburzenie czynności nerwu twarzowego w pracach innych autorów występowało u 23,1\% do $40,1 \%$ operowanych chorych $[16,25]$. Natomiast trwałe zaburzenie czynności nerwu VII, według danych z piśmiennictwa, stwierdzono u $2 \%$ do $20 \%$ chorych po parotidektomii zachowawczej (w tym całkowite porażenie u 4\% do 15\%) [25, 54, 77, 109]. Według Huanga i wsp., wysokie ryzyko pooperacyjnego niedowładu nerwu twarzowego jest związane z wielkością guza powyżej $4 \mathrm{~cm}$, lokalizacją w płacie głębokim oraz śródoperacyjnymi cechami jego naciekania, natomiast nie zależy od wieku i płci chorego oraz utkania histologicznego nowotworu [48]. Wyniki te mogą tłumaczyć wyższy niż u innych autorów odsetek chorych z przejściowym niedowładem nerwu VII w naszym materiale, gdyż u większości leczonych przez nas pacjentów występował co najmniej jeden z powyższych czynników ryzyka. Ellingson i wsp. wykazali również, że przemijający niedowład nerwu twarzowego po parotidektomii zacho- 
wawczej występuje częściej w grupie chorych z nowotworami złośliwymi w porównaniu z pacjentami ze zmianami łagodnymi, jednakże odsetek trwałego upośledzenia czynności tego nerwu jest jednakowy w obu tych grupach [25].

Krwiak w ranie, zakażenie lub martwicę płata skórnego obserwowano łącznie w 14,5\% przypadków. Kolejnym powikłaniem, które dotyczyło 8,4\% chorych była retencja śliny w ranie lub przetoka ślinowa. Ponadto u 7 pacjentów wystapił szczękościsk, z czego u 2 bez uprzednich zaburzeń w otwierania jamy ustnej. Odsetek tych powikłań w materiale innych autorów był niższy, co prawdopodobnie związane jest z większym zakresem operacji u naszych chorych, a także innymi czynnikami takimi jak wiek, stan odżywienia, choroby współistniejące [16, 77].

Zespół Frey (pocenie smakowe) rozpoznano u 9,0\% chorych w toku dalszej obserwacji, natomiast w pracy Pedersena i wsp. powikłanie to rozpoznano u $4 \%$ pacjentów [77]. Wydaje się, że rzeczywisty odsetek chorych z zespołem Frey jest niemożliwy do oszacowania w badaniu retrospektywnym.

\subsection{Wyniki leczenia oraz wartość rokownicza wybranych czynników}

W analizowanym materiale 5-letnie przeżycie zależne od choroby oraz przeżycie całkowite wynosiły 57,0\%, natomiast przeżycie bezobjawowe 50,0\%. Szacunkowa wartość 10-letniego bezobjawowego i całkowitego przeżycia wynosiła odpowiednio $41,0 \%$ i 34,0\%. W pracach innych autorów 5-letnie bezobjawowe przeżycie było wyższe niż u naszych chorych i wahało się od $60 \%$ do $77 \%[39,54,77,98$, 124]. Według danych z piśmiennictwa 5-letnie przeżycie zależne od choroby wynosiło od $59 \%$ do $72 \%$, a przeżycie całkowite od $52 \%$ do $71 \%$ pacjentów leczonych z powodu raka ślinianki przyusznej [34, 39, 55, 80, 112]. 
W materiale Carrillo i wsp. 10-letnie przeżycie całkowite i bezobjawowe wynosiło odpowiednio 74\% i 60\% - wyniki te są dużo lepsze niż własne [16]. Gorsze wyniki leczenia u naszych chorych można wytłumaczyć wyższym odsetkiem pacjentów z III i IV stopniem zaawansowania klinicznego i wysokim stopniem złośliwości raka (przeżycie bezobjawowe i zależne od choroby), a co za tym idzie, większym ryzykiem wystąpienia wznowy miejscowo-węzłowej i/lub przerzutów odległych, a także chorobami współistniejącymi i wiekiem (przeżycie całkowite).

Wykonano analizę jednoczynnikową parametrów klinicznych i patologicznych celem poznania ich wpływu na 5-letnie bezobjawowe przeżycie (wyleczenie) oraz ich przydatności prognostycznej. Na podstawie jej wyników wykazano, że wiek równy lub powyżej 60 lat oraz płeć męska były związane w sposób statystycznie znamienny z niekorzystnym rokowaniem i zmniejszały szanse wyleczenia odpowiednio 2,4 i 2,6 razy.

Spośród objawów nowotworu czynnikiem najbardziej wpływającym na wyniki leczenia był niedowład lub porażenie nerwu twarzowego, gdyż jego obecność zmniejszała szanse na wyleczenie 9,7 razy. Kolejnymi czynnikami związanymi z niekorzystnym rokowaniem były naciek skóry, obecność powiększonych węzłów chłonnych na szyi oraz unieruchomienie guza, ponieważ pogarszały je odpowiednio 4,0, 3,4 i 3,1 razy. Dolegliwości bólowe i dynamika wzrostu guza nie wpływały w sposób istotny statystycznie na wyniki leczenia. Również liczba objawów złośliwości miała znaczenie prognostyczne, gdyż stwierdzono różnice statystycznie znamienne w wyleczeniu pomiędzy chorymi bez tych objawów w porównaniu z pacjentami z jednym lub dwoma oraz z grupa z co najmniej trzema objawami złośliwości (odpowiednio $71,4 \%$ vs $51,8 \%$ vs $31,2 \%$ ). W analizie jednoczynnikowej stwierdzono ponadto znamienne różnice w odsetku wyleczonych chorych w zależności od wielkość guza. 
Szansa nawrotu choroby była 2,9 razy większa u pacjentów z guzem większym niż 4 $\mathrm{cm}$ w porównaniu z chorymi ze zmianą $<4 \mathrm{~cm}$. Zaawansowanie narządowe wpływało w sposób istotny na 5-letnie bezobjawowe przeżycie, ponieważ istniały różnice w wyleczeniu chorych z poszczególnymi jego stopniami (T1 - 81,8\%, T2 - 74,3\%, T3 - 66,7\%,T4 - 18,7\%). Stopień T4 wiązał się z 12,2 razy gorszym rokowaniem w porównaniu z zaawansowaniem T1-T3. W analizie jednoczynnikowej stwierdzono również istotne różnice w wyleczeniu w zależności od stopnia zaawansowania klinicznego (I - 88,9\%, II - 73,3\%, III - 73,2\%, IV - 21,5\%). Chorzy z zaawansowaniem klinicznym I-III mieli 11,4 razy większą szansę na wyleczeniu w porównaniu z pacjentami z IV stopniem. W analizie jednoczynnikowej różnice znamienne statystycznie w wyleczeniu stwierdzono wyłącznie pomiędzy pacjentami z T4 w porównaniu z chorymi T1-T3 (zaawansowanie narządowe) oraz między grupą ze stopniem IV w porównaniu z chorymi z I-III (zaawansowanie kliniczne).

Z niekorzystnym rokowaniem związane było również zajęcie przestrzeni przygardłowej, naciekanie mięśni, a także naciekanie pozagruczołowe (odpowiednio 9,8, 3,5 i 5,4 razy mniejsze szanse wyleczenia). Chorzy, u których nowotwór zlokalizowany był w płacie powierzchownym mieli 2,8 razy większą szansę wyleczenia w porównaniu z pacjentami z rakiem obejmującym płat głęboki lub cały gruczoł. Nie stwierdzono natomiast różnic istotnych statystycznie w wyleczeniu u chorych z zaawansowaniem T4 w zależności od obecności naciekania nerwu VII lub skóry.

Spośród wyników pooperacyjnego badania histologicznego największy wpływ na wyleczenie miała obecność przerzutów do węzłów chłonnych śródśliniankowych oraz szyjnych, które odpowiednio 9,8 i 6,7 razy zmniejszały jego szanse. Wysoki stopień złośliwości raka wiązał się z 8,2 razy większym ryzykiem nawrotu choroby w porównaniu z grupą chorych z nowotworami o niskim lub pośrednim 
stopniu złośliwości. Mniejszy wpływ na szansę 5-letniego bezobjawowego przeżycia miał stan marginesów chirurgicznych, wątpliwy lub dodatni zwiększał ryzyko niepowodzenia leczenia 3,1 razy w porównaniu z ujemnym marginesem.

Wyniki analizy jednoczynnikowej innych autorów potwierdzają obserwacje własne. Według danych z piśmiennictwa istotny statystycznie wpływ na 5-letnie przeżycie maja następujące czynniki: wiek [7, 16, 55, 80, 112], płeć męska [50], niedowład lub porażenie nerwu twarzowego [39, 43, 50, 55, 77, 80, 109, 112], zaawansowanie narządowe [16, 39, 43, 50, 55], zaawansowanie regionalne [43], zaawansowanie kliniczne [7, 39,54, 55, 77, 80, 112], stopień złośliwości [7, 16, 43, 55, 77, 114, 124], przerzuty do węzłów chłonnych szyi [7, 39, 50, 55, 112], stan marginesów chirurgicznych $[16,114]$ oraz naciekanie pozagruczołowe [43, 77]. Natomiast Godballe i wsp., odmiennie niż w niniejszej pracy, wykazali, że również ból jest czynnikiem wpływającym w sposób istotny statystycznie na wyleczenie [39]. Ponadto w wielu pracach stwierdzono znamienne statystycznie różnice w wyleczeniu w zależności od utkania histologicznego raka [16, 39, 43, 55, 80, 112], a Witten i wsp. oraz Pedersen i wsp. wykazali, że rak w gruczolaku wielopostaciowym wiązał się z najgorszym rokowaniem $[77,120]$. Pohar i wsp. stwierdzili również na podstawie wyników analizy jednoczynnikowej, że naciekanie okołonerwowe było istotnym statystycznie czynnikiem rokowniczym [80].

Celem poznania przydatności prognostycznej badanych parametrów wykonano analizę wieloczynnikową ich wpływu na 5-letnie bezobjawowe przeżycie (wyleczenie). Wśród objawów i odchyleń w badaniu klinicznym występujących w raku ślinianki przyusznej, takich jak zaburzenie czynności nerwu VII, naciek skóry, powiększone węzły chłonne szyi, ból oraz unieruchomienie i szybki wzrost guza, niezależnymi czynnikami wpływającymi istotnie statystycznie na prawdopodobieństwo 
wyleczenia jest niedowład lub porażenie nerwu twarzowego oraz naciek skóry. Spośród struktur anatomicznych zajętych przez nowotwór, naciek żuchwy, nerwu twarzowego i skóry okazały się być niezależnymi czynnikami wpływającymi istotnie statystycznie na prawdopodobieństwo 5-letniego bezobjawowego przeżycia. Pozostałe oceniane czynniki, takie jak naciek postawy czaszki, przestrzeni przygardłowej, mięśnia żwacza oraz przewodu słuchowego zewnętrznego okazały się nie być istotne statystycznie w ocenianym modelu wieloczynnikowym. Wśród parametrów zależnych od nowotworu, zaawansowanie narządowe i stopień złośliwości guza były niezależnymi czynnikami wpływającymi istotnie statystycznie na wyleczenie. Zaawansowanie regionalne nie wpływało w sposób istotny statystycznie w ocenianym modelu wieloczynnikowym na wyleczenie. Z parametrów kliniczno-patologicznych, takich jak wiek, płeć, zaawansowanie kliniczne, obecność przerzutów do węzłów chłonnych szyi oraz stan marginesów mikroskopowych niezależnymi czynnikami wpływającymi istotnie statystycznie na prawdopodobieństwo wyleczenia były wiek, zaawansowanie kliniczne oraz zajęcie regionalnych węzłów chłonnych. Pozostałe ocenianie czynniki okazały się nie być istotne statystycznie w ocenianym modelu wieloczynnikowym. W pracach innych autorów na postawie wyników analizy wieloczynnikowej uznano za istotne statystycznie następujące czynniki rokownicze: wiek [7, 80, 112], zaawansowanie narządowe [3, 43, 55], zaawansowanie regionalne [43], zaawansowanie kliniczne [7, 54, 55, 80, 112], stopień złośliwości [3, 7, 43, 55], przerzuty do regionalnych węzłów chłonnych $[7,50,54,112]$, stan marginesów chirurgicznych [114] oraz naciekanie pozagruczołowe [43]. Terhaard i wsp. wykazali ponadto, iż porażenie nerwu twarzowego jest niezależnym czynnikiem wpływającym na częstość wznów regionalnych i przeżycie bezobjawowe [109]. Na podstawie analizy wieloczynnikowej Poorten i wsp. stworzyli czterostopniową skalę prognostycz- 
ną. Uwzględnia ona zarówno czynniki przed jak i pooperacyjne, takie jak wiek, obecność dolegliwości bólowych, czynność nerwu twarzowego, zaawansowanie narządowe i kliniczne, stan marginesów chirurgicznych, naciekanie skóry i okołonerwowe. Według tej skali, 5-letnie bezobjawowe przeżycie waha się od 95\% dla stopnia pierwszego do $42 \%$ w stopniu czwartym [81]. Skala ta została rozwinięta na podstawie danych uzyskanych z ośrodków w Holandii, Belgii i Niemczech. Zawiera ona cztery stopnie ryzyka nawrotu choroby na podstawie czynników przedoperacyjnych (wiek, ból, zaawansowanie narządowe i regionalne, naciek skóry, czynność nerwu twarzowego), jak również cztery stopnia ryzyka z uwzględnieniem czynników pooperacyjnych, takich jak wiek, zaawansowanie narządowe i regionalne, naciek skóry, naciekanie nerwu VII, naciekanie okołonerwowe, stan marginesów chirurgicznych. Według tej skali, 5-letnie bezobjawowe przeżycie wynosi od $94 \%$ do $42 \%$ z uwzględnieniem czynników przedoperacyjnych oraz od 93\% do $40 \%$ na podstawie czynników pooperacyjnych [83]. Powyższe wyniki potwierdzają obserwacje własne dotyczące niezależnych czynników rokowniczych w raku ślinianki przyusznej.

\subsection{Niepowodzenie leczenia}

W naszym materiale niepowodzenie leczenia pod postacią nawrotu nowotworu obserwowano u 50,5\% pacjentów. Wyniki własne są porównywalne z wynikami innych autorów - od 33\% do 53,5\% [16, 55, 112]. Wznowa miejscowa wystapiła u $16,5 \%$ leczonych przez nas chorych. Nawrót choroby miał charakter wieloogniskowy u 15,6\% pacjentów, a u kolejnych 14,7\% ujawniły się przerzuty odległe (bez cech wznowy miejscowej lub węzłowej). Izolowana wznowa węzłowa w naszym materiale była bardzo rzadka - jedynie u 3,7\% chorych. Odsetek chorych ze wznową 
miejscową w piśmiennictwie wynosił od $13 \%$ w materiale Zbärena i wsp. do $28 \%$ u Harbo i wsp. [43, 55, 86, 114, 120, 124]. Wznowa węzłowa występowała w pracach innych autorów u 3,7\% do $19 \%$ chorych $[43,55,86,124]$. Wznowa wieloogniskowa, według danych z piśmiennictwa, była przyczyną niepowodzenia leczenia u $4 \%$ do $23 \%$ (miejscowo-węzłowa) oraz u $4 \%$ do 9,6\% chorych (wznowa miejscowo-węzłowa i przerzut odległy) $[34,54,55,80,124]$. Odsetek chorych, u których wystąpiły przerzuty odległe w wynikach innych autorów wynosił od $5 \%$ do $26,6 \%$ [34, 39, 43, 54, 55, 77, 80, 85, 86, 112, 114, 124]. Liczba pacjentów z poszczególnymi rodzajami nawrotów nowotworu w naszym materiale jest zbliżona do średnich wartości podawanych w piśmiennictwie.

Według Gallo i wsp., najważniejszym czynnikiem wpływającym na niepowodzenie leczenia jest przerzut odległy. W analizie jednoczynnikowej wykazali oni, że podwyższone ryzyko ich wystąpienia jest związane z obecnością przerzutów węzłowych, wysokim zaawansowaniem klinicznym i stopieniem złośliwości guza, naciekaniem pozagruczołowym oraz zaburzeniem czynności nerwu twarzowego. W analizie wieloczynnikowej udowodnili natomiast, iż niezależnymi czynnikami ryzyka przerzutów odległych są zaawansowanie kliniczne, wielkość guza, obecność nacieku skóry, mięśni lub kości oraz niedowład lub porażenie nerwu VII [34].

Przerzuty odległe w liczbie 34 ujawniły się u 28 naszych chorych. Najczęściej były to przerzuty do płuca, następnie do kości, wątroby, mózgu, pozaregionalnych węzłów chłonnych oraz do skóry. W pracy Zbärena i wsp. przerzuty odległe u części pacjentów $(15,1 \%)$ również miały charakter wieloogniskowy [124]. Przerzuty odległe w zestawieniach innych autorów, podobnie jak w naszym materiale, były najczęściej zlokalizowane w płucach $(42,4 \%$ do $100 \%$ chorych), kościach (9\% $30 \%)$, wątrobie $(7,7 \%$ - 19\%) oraz mózgu $(6 \%$ - 12,1\%). Rzadziej dotyczyły węzłów 
chłonnych śródpiersia, skóry, śledziony, nadnerczy i nerek [16, 34, 39, 55, 77, 114, $120,124]$.

Ponad $80 \%$ nawrotów u naszych chorych wystapiło w ciagu pierwszych 3 lat obserwacji. Czas wystąpienia wznowy miejscowej wahał się od 2 do 108 miesięcy (średnio 21,8), regionalnej - od 6 do 88 miesięcy (średnio 23,7). Przerzuty odległe występowały w okresie od 2 do 84 miesięcy (średnio 22,8) od zakończenia pierwotnego leczenia. Czas wystąpienia poszczególnych rodzajów nawrotu nowotworu był podobny w pracach innych autorów. W materiale Wittena i wsp. 2/3 wznów miejscowych obserwowano w ciagu pierwszych 2 lat [120]. Zbären i wsp. podają, że średni czas pojawienia się wznowy miejscowej wynosił 18 miesięcy, wznowy węzłowej 20 miesięcy, a przerzutów odległych - 19 miesięcy od zakończenia leczenia [124]. Natomiast w materiale Regis De Brito Santosa i wsp. wznowa miejscowa i/lub węzłowa występowała później - między 34 a 153 miesiącem katamnezy (średnio po 37,8 miesiącach) [86].

Odsetek chorych, u których wystąpił nawrót choroby nowotworowej był zróżnicowany w zależności od zaawansowania klinicznego, stopnia złośliwości i utkania histologicznego raka ślinianki. Najwięcej nawrotów miejscowych obserwowano w IV i II stopniu zaawansowania klinicznego (odpowiedni u 44,2\% i 26,7\% chorych). W grupie pacjentów z III stopniem zaawansowanie klinicznego wznowa miejscowa wystąpiła tylko u 5,5\% z nich, natomiast nie obserwowano jej w stopniu I. Odwrotną tendencję obserwowali Tullio i wsp., którzy wznowę miejscową stwierdzili w połowie przypadków T1 lub T2 [114]. U naszych chorych nie obserwowano istotnych różnic w liczbie wznów węzłowych między II, III i IV stopniem zaawansowania klinicznego, wzrastała natomiast częstość przerzutów odległych wraz z kolejnymi jego stopniami. 
W naszym materiale występowała znaczna różnica między częstością wznów miejscowych $\mathrm{w}$ rakach o wysokim stopniu złośliwości $\mathrm{w}$ porównaniu $\mathrm{z}$ rakami o pośrednim/niskim stopniu złośliwości (odpowiednio 35,5\% vs 15,1\%). Nie obserwowano natomiast tak dużych rozbieżności w przypadku wznów węzłowych $(17,1 \%$ vs $12,1 \%)$. Odwrotną tendencję stwierdzili u swoich chorych Zbären i wsp., wśród których nie obserwowano istotnych różnic w odsetku wznów miejscowych $(12,5 \%$ vs $14 \%$ ), obserwowano natomiast znaczne różnice w częstości wznów węzłowych w rakach o wysokim stopniu złośliwości w porównaniu z nowotworami o niskiej złośliwości (16\% vs 6\%) [124]. Odsetek przerzutów odległych u leczonych przez nas chorych był wyraźnie zróżnicowany w zależności od stopnia złośliwości i wynosił 35,5\% w grupie z rakami o wysokim stopniu złośliwości i tylko 3\% u pacjentów z nowotworami o niski lub pośrednim stopniu złośliwości. Podobne różnice wykazali Zbären i wsp. (16\% vs 4,1\%) oraz Gallo i wsp. (30,6 vs 17,9\%) [34, 124].

W naszym materiale najwięcej wznów miejscowych obserwowano u chorych z gruczolakorakiem - 50,0\%, rzadziej stwierdzano je w raku gruczołowotorbielowatym $(27,8 \%)$, raku śluzowo-naskórkowym $(25,0 \%)$, raku w gruczolaku wielopostaciowym $(23,8 \%)$ oraz raku płaskonabłonkowym (u 2 z 6 pacjentów). Podobna tendencja występowała w zestawieniu Wittena i wsp. [120].

Wznowa regionalna u naszych chorych najczęściej występowała w raku śluzowo-naskórkowym oraz raku w gruczolaku wielopostaciowym (odpowiednio $20,0 \%$ i $19,0 \%)$, nieco rzadziej w raku gruczołowo-torbielowatym $(16,7 \%)$ i tylko u 9,1\% pacjentów z gruczolakorakiem bliżej nieokreślonym. W materiale Harbo i wsp., podobnie jak w naszym, wznowę węzłową najczęściej obserwowano u pacjentów z rakiem śluzowo-naskórkowym - 29\%, natomiast odmiennie niż w analizowanym materiale wystapiła ona u $28 \%$ chorych z gruczolakorakiem i u $21 \%$ 
z rakiem niezróżnicowanym [43]. Powyższe różnice w odsetkach wznów miejscowych i regionalnych można wytłumaczyć odmiennym zaawansowaniem klinicznym i stopniem złośliwości raków. Istotny jest również rodzaj pierwotnego leczenia postępowanie względem nerwu VII, wykonanie (zakres) operacji węzłowej oraz stosowanie uzupełniającego napromieniania.

Przerzuty odległe w naszym materiale najczęściej występowały w złośliwym gruczolaku wielopostaciowym (42,8\%), rzadziej w raku niezróżnicowanym, raku gruczołowo-torbielowatym oraz gruczolakoraku. W raku śluzowo-naskórkowym stwierdzono je jedynie u 10\% pacjentów. Terhaard i wsp. wykazali, że występowanie przerzutów odległych w raku ślinianki przyusznej zależy od jego utkania histologicznego [109]. W materiale Pedersena i wsp., podobnie jak w naszym, przerzuty odległe najczęściej stwierdzano u chorych z rakiem w gruczolaku wielopostaciowym [77]. Również wyniki innych autorów były zbliżone do własnych. Największy odsetek przerzutów odległych występował w raku gruczołowo-torbielowatym (24\%64\%), raku niezróżnicowanym (23\%-63,6\%), raku w gruczolaku wielopostaciowym (17\%-43\%) oraz w gruczolakoraku (18\%-35,5\%). Przerzuty odległe w raku śluzowonaskórkowym w piśmiennictwie stwierdzano w 11\% do 17,2\% przypadków [30, 34, $39,85,114,120]$. Gallo i wsp. podają również częste występowanie przerzutów odległych u chorych z rakiem płaskonabłonkowym oraz zrazikowokomórkowym. (około $19 \%$ ) [34].

Leczenie podjęto u 68,7\% naszych chorych ze wznową miejscową i u 94,1\% ze wznową regionalną. Wyłącznie chirurgicznie lub metodą skojarzoną z radiolub chemioterapią leczono 31,2\% wznów miejscowych i 70,6\% nawrotów węzłowych. W pozostałych przypadkach stosowano radioterapię, radiochemioterapię lub paliatywną chemioterapię. W materiale Leversteina i wsp. leczenie chirurgiczne 
lub skojarzone zastosowano u 33,3\% chorych ze wznową miejscową lub miejscowowęzłową [54]. Wyniki te potwierdzają własne obserwacje dotyczące ograniczonych możliwości zastosowania leczenia chirurgicznego w przypadku nawrotów miejscowych raka ślinianki przyusznej. 


\section{WNIOSKI}

Na podstawie analizy danych kliniczno-patologicznych oraz oceny wyników leczenia chorych z pierwotnym rakiem ślinianki przyusznej można przedstawić poniższe wnioski:

1. Analizowany materiał 131 chorych charakteryzuje się następującymi cechami:

- rak ślinianki przyusznej występuje najczęściej w średnim i starszym wieku, z niewielką przewagą kobiet;

- w części przypadków rak ślinianki może manifestować się wyłącznie jako wolno rosnący guz;

- objawy złośliwości wiążą się z wysokim zaawansowaniem klinicznym;

- najczęstszy typ histologiczny to: gruczolakorak bliżej nieokreślony, rak w gruczolaku wielopostaciowym, rak śluzowo-naskórkowy oraz rak gruczołowo-torbielowaty; dominują raki o wysokim stopniu złośliwości (high grade)

- stopień złośliwości nowotworu jest czynnikiem mającym największy wpływ na przebieg kliniczny;

- przerzuty do węzłów chłonnych szyi rozpoznano u 41\% chorych, w tym u $30 \%$ pacjentów z węzłami N0, co wskazuje na konieczność wykonywania elektywnych operacji węzłowych;

- lokalizacja guza w płacie głębokim ślinianki wiąże się z dużym ryzykiem wystąpienia pooperacyjnego niedowładu nerwu twarzowego;

2. 5-letnie przeżycie bezobjawowe (DFS) uzyskano u 50,0\% chorych, natomiast 5letnie przeżycie zależne od choroby (DSS) oraz przeżycie całkowite (OS) wynosiły 57,0\%. Przyczyną niepowodzenia leczenia były wznowa miejscowa, przerzuty odległe lub wznowa wieloogniskowa. 
3. Czynniki wpływające istotnie statystycznie na wyniki leczenia to: wiek chorych, stopień złośliwości raka, zaawansowanie narządowe i kliniczne, porażenie nerwu twarzowego, naciekanie skóry, naciekanie żuchwy oraz przerzuty do węzłów chłonnych szyi. 


\section{STRESZCZENIE}

Rak ślinianki przyusznej należy do najbardziej heterogenicznych pod względem budowy histologicznej i przebiegu klinicznego nowotworów występujących u człowieka. Mimo stałego postępu w diagnostyce i leczeniu, stanowi duże wyzwanie dla onkologów i chirurgów głowy i szyi.

Celem pracy była analiza danych kliniczno-patologicznych chorych z tym nowotworem, ocena odległych wyników leczenia oraz czynników rokowniczych.

Materiał stanowiło 131 chorych leczonych w Klinice Chorób Uszu, Nosa, Gardła i Krtani Gdańskiego UM w latach 1978 - 2008.

$\mathrm{W}$ analizowanej grupie obserwowano niewielką przewage kobiet $(53,4 \%)$. Stosunek K:M = 1,1:1. Średnia wieku wynosiła 58 lat. Najczęstszymi objawami i odchyleniami w badaniu były: obecność guza (96,9\%), ból (40,4\%), powiększone węzły chłonne szyi (32,0\%), niedowład lub porażenie nerwu VII (20,6\%) oraz naciek skóry $(19,8 \%)$. U około 1/5 chorych nie występowały objawy wskazujące na złośliwy charakter nowotworu. Średni czas trwania objawów (obecność guza) wynosił 51,3 miesięcy, a w przypadku objawów sugerujących proces złośliwy 4 miesiące. Cechy złośliwości guza na podstawie badania USG stwierdzono w 46,9\% przypadków. Badanie metodą TK lub MR pozwalało na bardziej precyzyjną niż USG ocenę rozległości procesu nowotworowego i potwierdzenie jego złośliwego charakteru (około 80\% wyników prawdziwie dodatnich). Czułość BAC w wykrywaniu złośliwego charakteru nowotworu wynosiła 56,2\%. Śródoperacyjne badanie histologiczne cechowało się 84,8\% czułością i 30,3\% zgodnością z ostatecznym rozpoznaniem histopatologicznym. Do oceny zaawansowania raków stosowano klasyfikację TNM. W materiale przeważali chorzy z trzecim i czwartym stopniem zaawansowania narządowego - łącznie 58,0\% i zaawansowaniem N0 (67,9\%). Nie było żadnego chorego z najwyższym stopniem (N3) zaawansowania regionalnego. Drugi pierwotny nowotwór złośliwy rozpoznano u 16,5\% chorych, najczęściej zlokalizowany był w skórze i miał charakter metachroniczny. W materiale dominowały raki o wysokim stopniu złośliwości (67,9\%), raki o pośrednim i niskim stopniu złośliwości stwierdzono u odpowiednio $6,1 \%$ i $25,9 \%$ chorych. Najczęściej występowały nowotwory o utkaniu gruczolakoraka bliżej nieokreślonego (19,0\%), raka w gruczolaku wielopostaciowym $(19,0 \%)$, raka śluzowo-naskórkowego $(18,3 \%)$ oraz raka gruczołowo- 
torbielowatego $(14,5 \%)$. Przerzuty do regionalnych węzłów chłonnych stwierdzono u 41,5\% chorych, z czego u 30,3\% chorych z zaawansowaniem N0.

W naszym materiale $44,3 \%$ chorych było leczonych wyłącznie chirurgicznie, a u 55,7\% zastosowano uzupełniające napromieniania. Parotidektomię zachowawczą wykonano u 42,7\% chorych, półzachowawczą u 16,0\% pacjentów, a radykalną u 41,2\%. U 82,4\% pacjentów wycięcie ślinianki uzupełniono operacją węzłową szyi, w tym u 50,3\% wykonano zabieg elektywny. Przemijający niedowład nerwu twarzowego był najczęstszym powikłaniem leczenia chirurgicznego (58,4\%), w większości przypadków związany był z umiejscowieniem guza w płacie głębokim. U 7,8\% uszkodzenie nerwu VII miało charakter trwały. Pozostałymi powikłaniami były krwiak w ranie, zakażenie lub martwica płata skórnego (14,5\%), przetoka ślinowa $(8,4 \%)$, szczękościsk (5,3\%) oraz zespół Frey $(9,0 \%)$.

Odległe wyniki leczenia opracowano na podstawie danych uzyskanych od 109 chorych, po wyłączeniu 12, który żyją a czas ich obserwacji był mniejszy niż 5 lat oraz 10 pacjentów, których dalszych losów nie zdołano ustalić. 5-letnie przeżycie zależne od choroby oraz przeżycie całkowite wynosiły po $57,0 \%$, natomiast przeżycie bezobjawowe 50,0\%. Szacunkowa wartość 10- i 15-letniego przeżycia bez objawów choroby wynosiła odpowiednio 41,0\% i 38,0\%. Przyczyną niepowodzenia leczenia były: wznowa miejscowa $(16,5 \%)$, wieloogniskowa $(15,6 \%)$ lub przerzut odległy $(14,7 \%)$. Izolowana wznowa węzłowa wystąpiła tylko u 3,7\% chorych. Leczenie podjęto w $68,7 \%$ przypadków wznów miejscowych i 94,1\% wznów regionalnych. Wyłącznie chirurgicznie lub metodą skojarzoną z radio- lub chemioterapią leczono 31,2\% wznów miejscowych i 70,6\% nawrotów węzłowych. W pozostałych przypadkach stosowano radioterapię, radiochemioterapię lub paliatywną chemioterapię.

Analizie jednoczynnikowej poddano 22 wybrane cechy kliniczne i patologiczne w celu określenia ich przydatności prognostycznej. Za poziom istotności statystycznej przyjęto $\mathrm{p}<0,05$. Na podstawie jej wyników wykazano, że wiek $\geq 60$ lat oraz płeć męska były związane w sposób statystycznie znamienny z niekorzystnym rokowaniem i zmniejszały szanse wyleczenia odpowiednio 2,4 i 2,6 razy. Spośród objawów czynnikiem najbardziej wpływającym na wyniki leczenia był niedowład lub porażenie nerwu twarzowego, gdyż jego obecność zmniejszała szanse na wyleczenie 9,7 razy. Kolejnymi czynnikami związanymi z niekorzystnym rokowaniem były naciek skóry, obecność powiększonych węzłów chłonnych szyi oraz unieru- 
chomienie guza, ponieważ pogarszały je odpowiednio 4,0, 3,4 i 3,1 razy. Dolegliwości bólowe i dynamika wzrostu guza nie wpływały w sposób istotny statystycznie na wyniki leczenia. Również liczba objawów złośliwości miała znaczenie prognostyczne, gdyż stwierdzono różnice statystycznie znamienne w wyleczeniu pomiędzy chorymi bez tych objawów w porównaniu z pacjentami z jednym lub dwoma oraz $\mathrm{z}$ tymi, u których występowały co najmniej trzy objawy złośliwości (odpowiednio 71,4\% vs $51,8 \%$ vs $31,2 \%$ ). W analizie jednoczynnikowej stwierdzono ponadto znamienne różnice w odsetku wyleczonych chorych w zależności od wielkości guza. Szansa nawrotu choroby była 2,9 razy większa u pacjentów z guzem większym niż $4 \mathrm{~cm}$ w porównaniu $\mathrm{z}$ chorymi ze zmianą $\leq 4 \mathrm{~cm}$. Zaawansowanie narządowe wpływało w sposób istotny na 5-letnie bezobjawowe przeżycie, ponieważ istniały różnice w wyleczeniu chorych z poszczególnymi jego stopniami (T1 - 81,8\%, T2 - 74,3\%, T3 - 66,7\%, T4 - 18,7\%). Stopień T4 wiązał się z 12,2 razy gorszym rokowaniem w porównaniu z zaawansowaniem T1-T3. W analizie jednoczynnikowej stwierdzono również istotne różnice w wyleczenie w zależności od stopnia zaawansowania klinicznego (I - 88,9\%, II - 73,3\%, III - 73,2\%, IV - 21,5\%). Chorzy z zaawansowanie klinicznym I-III mieli 11,4 razy większą szansę na wyleczeniu w porównaniu z pacjentami z IV stopniem. W analizie jednoczynnikowej różnice znamienne statystycznie w wyleczeniu stwierdzono wyłącznie pomiędzy pacjentami z T4 w porównaniu z chorymi T1-T3 (zaawansowanie narządowe) oraz między grupą ze stopniem IV w porównaniu z chorymi z I-III (zaawansowanie kliniczne). Z niekorzystnym rokowaniem związane było również zajęcie przestrzeni przygardłowej, naciekanie mięśni, a także naciekanie pozagruczołowe (odpowiednio 9,8, 3,5 i 5,4 razy mniejsze szanse wyleczenia). Chorzy, u których nowotwór zlokalizowany był w płacie powierzchownym mieli 2,8 razy większą szansę wyleczenia w porównaniu z pacjentami z rakiem obejmującym płat głęboki lub cały gruczoł. Nie stwierdzono natomiast istotnych statystycznie różnic $\mathrm{w}$ wyleczeniu u chorych z zaawansowaniem T4 w zależności od obecności naciekania nerwu VII lub skóry. Spośród wyników pooperacyjnego badania histologicznego największy wpływ na wyleczenie miała obecność przerzutów do węzłów chłonnych śródśliniankowych oraz szyjnych, które odpowiednio 9,8 i 6,7 razy zmniejszały jego szanse. Wysoki stopień złośliwości raka wiązał się z 8,2 razy większym ryzykiem nawrotu choroby w porównaniu z grupą chorych z nowotworami o niskim lub pośrednim stopniu złośliwości. Mniejszy wpływ na szansę 5-letniego bezobjawowego przeżycia miał stan marginesów chirurgicz- 
nych, wątpliwy lub dodatni zwiększał ryzyko niepowodzenia leczenia 3,1 razy w porównaniu z ujemnym marginesem.

Na podstawie analizy wieloczynnikowej stwierdzono, że wśród objawów niezależnymi czynnikami rokowniczymi okazały się być niedowład/porażenie nerwu twarzowego oraz naciek skóry, zaś wśród struktur anatomicznych zajętych przez nowotwór - naciekanie żuchwy, nerwu twarzowego i skóry. Wśród parametrów zależnych od nowotworu niezależnymi czynnikami, wpływającymi istotnie statystycznie na wyleczenie, były zaawansowanie narządowe i stopień złośliwości guza, zaś spośród parametrów kliniczno-patologicznych - wiek, zaawansowanie kliniczne oraz przerzuty do węzłów chłonnych szyi. 


\section{SUMMARY}

The parotid carcinoma is one of the most heterogenic neoplasms, in regard to histological structure and clinical course. Despite development of the diagnostics tools and treatment methods, it remains a challenge for oncologists and head and neck surgeons.

The aim of this study was to analyze clinical and pathological data of the patients with parotid gland carcinoma as well as to assess treatment results and prognostic factors.

The material consisted of 131 patients treated in the Department of Otolaryngology of Medical University of Gdańsk between 1978 and 2008.

A small predominance of women $(53,4 \%)$ was observed in the investigated group. Female to male ratio was 1,1:1. The average age was 58 years. The most common symptoms and clinical findings were: presence of a tumor $(96,9 \%)$, pain $(40,4 \%)$, cervical lymphadenopathy $(32,0 \%)$, facial nerve palsy $(20,6 \%)$, skin infiltration $(19,8 \%)$. There were no symptoms or signs of malignancy in about $1 / 5$ of the patients. The average duration of the symptoms (presence of a tumor) was 51,3 months and in case of symptoms suggesting malignancy -4 months. Findings indicating potential malignancy in ultrasonography were found in $46,9 \%$ of the cases. MR and CT imaging enabled more precise than ultrasonography estimation of the extension and confirmation of its malignant character (about $80 \%$ true positive results). Sensitivity of the FNAC in detection of malignant character of neoplasm averaged $56,2 \%$. Frozen section featured with $84,8 \%$ sensitivity and 30,3\% accuracy when compared to the final histological diagnosis. The stage of the cancer was assessed according to TNM classification. There was a predominance of the patients with T3/T4 (in total 58,0\%) and N0 stage $(67,9 \%$ ). There were no patients with N3 stage. The second malignant primary occurred in $16,5 \%$ of the patients with the most common localization in the skin. The high grade carcinomas were the most frequent $(67,9 \%)$, intermediate and low grade carcinomas were observed respectively in $6,1 \%$ and $25,9 \%$. The most common histological types were: adenocarcinoma not other specified (19,0\%), carcinoma ex pleomorphic adenoma (19,0\%), mucoepidermoid carcinoma $(18,3 \%)$ and adenoid cystic carcinoma (14,5\%). Regional lymph node metastases were found in $41,5 \%$ of the patients and in 30,3\% of them with N0 stage. 
In $44,3 \%$ of cases the treatment was limited only to the surgical procedure and in remaining $55,7 \%$ of cases the complementary radiation therapy was applied. Conservative parotidectomy was performed in $42,7 \%$ of the patients, semiconservative in $16,0 \%$ and radical in $41,2 \%$. The parotid surgery was followed by neck dissection in $82,4 \%$ of the patients, elective neck dissection was performed in $50,3 \%$ of them. Transient facial nerve palsy was the most frequent complication of the surgical treatment $(58,4 \%)$ and was connected with the localization of the tumor in the deep lobe in most of the cases. The permanent facial nerve lesion was observed in $7,8 \%$. The other complications were: wound haematoma, infection or skin flap necrosis $(14,5 \%)$, salivary fistula $(8,4 \%)$, trismus $(5,3 \%)$ and Frey`s syndrome $(9,0 \%)$.

The treatment results were assessed in the group of 109 patients, after exclusion of 12, who are alive but their follow-up period was shorter than 5 years, and 10 lost to follow-up. 5-year overall and disease-specific survival were observed in $57,0 \%$ of the patients and 5-years disease-free survival was achieved in 50,0\%. Estimated value of 10 - and 15-year disease-free survival was $41,0 \%$ and $38,0 \%$ respectively. The treatment failures were: local $(16,5 \%)$, multifocal $(15,6 \%)$ recurrences or distant metastasis $(14,7 \%)$. Isolated regional recurrence occurred only in $3,7 \%$ of the patients. Salvage treatment was performed in $68,7 \%$ of local and in $94,1 \%$ of regional recurrences. Surgery alone or with combination of radio- or chemotherapy was applied in $31,2 \%$ of local and $70,6 \%$ of regional recurrences. The remaining cases were treated with radiation therapy, radiochemotherapy or palliative chemotherapy.

Univariate analysis included 22 clinical and pathological features to assess their prognostic value was done. Age $\geq 60$ years and male gender were statistically significant $(\mathrm{p}<0,05)$ and correlated with poor prognosis and decreased chance for recovery respectively 2,4 and 2,6 times. Facial nerve palsy was the factor with the highest influence on the treatment result among all symptoms, because its presence decreased the chance for recovery 9,7 times. Skin infiltration, cervical lymphadenopathy and tumor fixation were other factors connected with poor prognosis (worse 4,0, 3,4 and 3,1 times respectively). Pain and rapid tumor enlargement had no statistically significant influence on the treatment results. The numbers of symptoms or signs of malignancy had a prognostic value too. 5-years disease-free survival was achieved in $71,4 \%$ without, in $51,8 \%$ with one or two and in $31,2 \%$ patients with at 
least three symptoms or signs of malignancy. Furthermore, statistically significant differences in percentage of cured patients in regard to the tumor size were found in univariate analysis. A chance for a recurrence was 2,9 times higher in patients with a tumor larger than $4 \mathrm{~cm}$ in comparison to persons with $\leq 4 \mathrm{~cm}$ lesion. T-status had important influence on the 5-years disease-free survival, because there were significant differences in treatment result between its stages (T1-81,8\%, T2-74,3\%, T3$66,7 \%$, T4-18,7\%). T4 stage was connected with 12,2 times worse prognosis in comparison to T1-T3. Statistically significant differences in recovery regarding the clinical stage were found in univariate analysis (I - 88,9\%, II -73,3\%, III -73,2\%, IV $21,5 \%$ ). Patients with stage I-III had 11,4 times a higher chance for recovery in comparison to patients with stage IV. Parapharyngeal space involvement, muscle infiltration and extraparenchymal extension were connected with poor prognosis in our material (respectively 9,8, 3,5 and 5,4 times a smaller chance for recovery). The patients with tumor localized in superficial lobe had 2,8 times higher chance for recovery in comparison to persons with cancer involving deep lobe or the whole gland. No statistically significant differences were found in treatment result in patients with T4 stage regarding a presence of facial nerve or skin infiltration. Among histological examination results, the presence of cervical or intraglandular lymph node metastases had the highest influence on recovery, which decreased the chance 9,8 and 6,7 times respectively. High grade of the carcinoma was connected with 8,2 times higher risk of a recurrence in comparison with low or intermediate grade neoplasm. The state of surgical margins had lower influence on the 5-year disease-free survival, uncertain or positive increased 3,1 times the risk of treatment failure in comparison to negative margin.

In multivariate analysis it was proved that the independent prognostic factors among symptoms and signs were facial nerve palsy and skin infiltration, among anatomic structures involved by the neoplasm - mandible, facial nerve and skin infiltration. T-stage and grade had the statistically significant influence on the treatment result among tumor related factors as well as age, stage and lymph node metastases among clinical and pathological features. 


\section{PIŚMIENNICTWO}

1. Arabi Mianroodi AA, Sigston EA, Vallance NA. Frozen section for parotid surgery: should it become routine? ANZ J Surg, 2006, 76, 736-739.

2. Armstrong JG, Harrison LB, Spiro RH, Fass DE, Strong EW, Fuks ZY. Malignant tumors of major salivary gland origin. A matched-pair analysis of the role of combined surgery and postoperative radiotherapy. Arch Otolaryngol Head Neck Surg, 1990, 116, 290-293.

3. Armstrong JG, Harrison LB, Thaler HT, Friedlander-Klar H, Fass DE, Zelefsky MJ, Shah JP, Strong EW, Spiro RH. The indications for elective treatment of the neck in cancer of the major salivary glands. Cancer, 1992, 69, 615-619.

4. Auvinen A, Hietanen M, Luukkonen R, Koskela RS. Brain tumors and salivary gland cancers among cellular telephone users. Epidemiology, 2002, 13, 356359.

5. Barnes L, Eveson JW, Reichart P, Sidransky D [red.] World Health Organization classification of tumours. Pathology and genetics of head and neck tumours. IARC, Lyon, 2005.

6. Barnes L, Rao U, Krause J, Contis L, Schwartz A, Scalamogna P. Salivary duct carcinoma. Part I. A clinicopathologic evaluation and DNA image analysis of 13 cases with review of the literature. Oral Surg Oral Med Oral Pathol, 1994, 78, 64-73.

7. Bell RB, Dierks EJ, Homer L, Potter BE. Management and outcome of patients with malignant salivary gland tumors. J Oral Maxillofac Surg, 2005, 63, 917928.

8. Belsky JL, Takeichi N, Yamamoto T, Cihak RW, Hirose F, Ezaki H, Inoue S, Blot WJ. Salivary gland neoplasms following atomic radiation: additional cases and reanalysis of combined data in a fixed population, 1957-1970. Cancer, $1975,35,555-559$.

9. Berg HM, Jacobs JB, Kaufman D, Reede DL. Correlation of fine needle aspiration biopsy and CT scanning of parotid masses. Laryngoscope, 1986, 96, 13571362. 
10. Bhattacharyya N, Fried MP. Nodal metastasis in major salivary gland cancer: predictive factors and effects on survival. Arch Otolaryngol Head Neck Surg, 2002, 128, 904-908.

11. Bień S, Żyłka S, Mierzwa T, Okła S. Wartość oceny klinicznej i patologicznej w diagnostyce przedoperacyjnej nowotworów ślinianki przyusznej. Otolaryngol Pol, 1999, 53 Supl 30, 318-320.

12. Bień S. Standardy postępowania diagnostycznego i terapeutycznego w leczeniu nowotworów gruczołów ślinowych. Otorynolaryngologia, 2003, 2, 1-11.

13. Bozzato A, Zenk J, Greess H, Hornung J, Gottwald F, Rabe C, Iro H. Potential of ultrasound diagnosis for parotid tumors: analysis of qualitative and quantitative parameters. Otolaryngol Head Neck Surg, 2007, 137, 642-646.

14. Burduk PK, Betlejewski S, Burduk D, Burzyńska-Makuch M, Motyl D, Nawrot M, Boroń Z. Diagnostyka USG w chorobach dużych gruczołów ślinowych. Otolaryngol Pol, 1999, 53 Supl 30, 329-332.

15. Carinci F, Farina A, Pelucchi S, Calearo C, Fini-Storchi O, Merlo R, Pastore A. Parotid gland carcinoma: 1987 and 1997 UICC T classifications compared for prognostic accuracy at 5 years. Eur Arch Otorhinolaryngol, 2001, 258, 150154.

16. Carrillo JF, Vázquez R, Ramírez-Ortega MC, Cano A, Ochoa-Carrillo FJ, Oñate-Ocaña LF. Multivariate prediction of the probability of recurrence in patients with carcinoma of the parotid gland. Cancer, 2007, 15, 2043-2051.

17. Cheuk W, Chan JK. Advances in salivary gland pathology. Histopathology, 2007, 51, 1-20.

18. Cheuk W, Chan JK. Salivary gland tumors. W: Diagnostic Histopathology of Tumors. Fletcher CDM [red.]. Churchill Livingstone, 2000.

19. Colmenero C, Patron M, Sierra I. Acinic cell carcinoma of the salivary glands. A review of 20 new cases. J Craniomaxillofac Surg, 1991, 19, 260-266.

20. Costas A, Castro P, Martín-Granizo R, Monje F, Marrón C, Amigo A. Fine needle aspiration biopsy (FNAB) for lesions of the salivary glands. Br J Oral Maxillofac Surg, 2000, 38, 539-542.

21. Dalke K, Betlejewski S, Janicka-Beuth L, Grygiel M, Winiarski P. Guzy nowotworowe ślinianek przyusznych w materiale Bydgoskiej Kliniki Otolaryngologii w latach 1980-1994. Otolaryngol Pol, 1995, 49 Supl 20, 48-53. 
22. Deschler DG, Day T. [red.] Pocket guide to TNM staging of head and neck cancer and neck dissection classification. American Academy of Otolaryngology-Head and Neck Surgery Foundation, Inc, Alexandria, 2008.

23. Dimery IW, Jones LA, Verjan RP, Raymond AK, Goepfert H, Hong WK. Estrogen receptors in normal salivary gland and salivary gland carcinoma. Arch Otolaryngol Head Neck Surg, 1987, 113, 1082-1085.

24. Dori S, Trougouboff P, David R, Buchner A. Immunohistochemical evaluation of estrogen and progesterone receptors in adenoid cystic carcinoma of salivary gland origin. Oral Oncol, 2000, 36, 450-453.

25. Ellingson TW, Cohen JI, Andersen P. The impact of malignant disease on facial nerve function after parotidectomy. Laryngoscope, 2003, 113, 1299-1303.

26. Ellis GL, Auclair PL, Gnepp DR. Surgical Pathology of the Salivary Glands. WB Saunders, Philadelphia, 1991.

27. Ellis GL, Auclair PL. Tumours of the salivary glands. 3rd ed. Armed Forces Institute of Pathology, Washington, 1996.

28. Ellis GL, Corio RL. Acinic cell adenocarcinoma. A clinicopathologic analysis of 294 cases. Cancer, 1983, 52, 542-549.

29. Eneroth CM, Hamberger CA. Principles of treatment of different types of parotid tumors. Laryngoscope, 1974, 84, 1732-1734.

30. Eneroth CM. Incidence and prognosis of salivary-gland tumours at different sites. A study of parotid, submandibular and palatal tumours in 2632 patients. Acta Otolaryngol, 1970, 263, 174-178.

31. Eneroth CM. Salivary gland tumors in the parotid gland, submandibular gland, and the palate region. Cancer, 1971, 27, 1415-1418.

32. Eveson JW, Cawson RA. Salivary gland tumours. A review of 2410 cases with particular reference to histological types, site, age and sex distribution. $\mathbf{J}$ Pathol, 1985, 146, 51-58.

33. Foote FW, Frazell EL. Tumors of the major salivary glands. W: Atlas of Tumor Pathology, Armed Forces Institute of Pathology, 1954.

34. Gallo O, Franchi A, Bottai GV, Fini-Storchi I, Tesi G, Boddi V. Risk factors for distant metastases from carcinoma of the parotid gland. Cancer, 1997, 80, 844-851.

35. Gierek T, Majzel K, Jura-Szołtys E, Śląska-Kaspera A, Witkowska M, Klimczak-Gołąb L. Analiza histokliniczna guzów ślinianek przyusznych u chorych 
operowanych w okresie 20 lat w Klinice Laryngologii ŚlAM w Katowicach. Otolaryngol Pol, 2007, 61, 399-403.

36. Gnepp DR, Corio RL, Brannon RB. Small cell carcinoma of the major salivary glands. Cancer, 1986, 58, 705-714.

37. Gnepp DR. Malignant mixed tumors of the salivary glands: a review. Pathol Annu, 1993, 28, 279-328.

38. Gnepp DR. Sebaceous neoplasms of salivary gland origin: a review. Pathol Annu, 1983, 18, 71-102.

39. Godballe C, Schultz JH, Krogdahl A, Møller-Grøntved A, Johansen J. Parotid carcinoma: impact of clinical factors on prognosis in a histologically revised series. Laryngoscope, 2003, 113, 1411-1417.

40. Goto TK, Yoshiura K, Nakayama E, Yuasa K, Tabata O, Nakano T, Kawazu T, Tanaka T, Miwa K, Shimizu M, Chikui T, Okamura K, Kanda S. The combined use of US and MR imaging for the diagnosis of masses in the parotid region. Acta Radiol, 2001, 42, 88-95.

41. Guimaraes DS, Amaral AP, Prado LF, Nascimento AG. Acinic cell carcinoma of salivary glands: 16 cases with clinicopathologic correlation. J Oral Pathol Med, 1989, 18, 396-399.

42. Guzzo M, Andreola S, Sirizzotti G, Cantu G. Mucoepidermoid carcinoma of the salivary glands: clinicopathologic review of 108 patients treated at the National Cancer Institute of Milan. Ann Surg Oncol, 2002, 9, 688-695.

43. Harbo G, Bundgaard T, Pedersen D, Søgaard H, Overgaard J. Prognostic indicators for malignant tumours of the parotid gland. Clin Otolaryngol Allied Sci, 2002, 27, 512-516.

44. Harish K. Management of primary malignant epithelial parotid tumors. Surg Oncol, 2004, 13, 7-16.

45. Hermanek P, Sobin LH [red.]. UICC TNM classification of malignant tumours. $4^{\text {th }}$ ed. Springer-Verlag, Berlin, 1987.

46. Hoffman DA, McConahey WM, Fraumeni JFJr, Kurland LT. Cancer incidence following treatment of hyperthyroidism. Int J Epidemiol, 1982, 11, 218-224.

47. Horn-Ross PL, Ljung BM, Morrow M. Environmental factors and the risk of salivary gland cancer. Epidemiology, 1997, 8, 414-419. 
48. Huang CC, Tseng FY, Chen ZC, Hsu CJ, Ko JY, Lou PJ, Chen YS. Malignant parotid tumor and facial palsy. Otolaryngol Head Neck Surg, 2007, 136, 778782.

49. Keller AZ. Residence, age, race and related factors in the survival and associations with salivary tumors. Am J Epidemiol, 1969, 90, 269-277.

50. Kelley DJ, Spiro RH. Management of the neck in parotid carcinoma. Am J Surg, 1996, 172, 695-697.

51. Klonowski S, Smajkiewicz L, Semczuk B, Kupisz K, Horoch A. Zastosowanie tomografii komputerowej w ocenie topograficznej guzów ślinianek. Otolaryngol Pol, 1991, 45, 327-332.

52. Kopeć T, Szmeja Z. Wartość badania ultrasonograficznego we wstępnym różnicowaniu guzów ślinianek. Otolaryngol Pol, 1999, 53 Supl 30, 332-334.

53. Leung SY, Chung LP, Yuen ST, Ho CM, Wong MP, Chan SY. Lymphoepithelial carcinoma of the salivary gland: in situ detection of Epstein-Barr virus. J Clin Pathol, 1995, 48, 1022-1027.

54. Leverstein H, van der Wal JE, Tiwari RM, Tobi H, van der Waal I, Mehta DM, Snow GB. Malignant epithelial parotid gland tumours: analysis and results in 65 previously untreated patients. Br J Surg, 1998, 85, 1267-1272.

55. Lima RA, Tavares MR, Dias FL, Kligerman J, Nascimento MF, Barbosa MM, Cernea CR, Soares JR, Santos IC, Salviano S. Clinical prognostic factors in malignant parotid gland tumors. Otolaryngol Head Neck Surg, 2005, 133, 702708.

56. Lin AC, Bhattacharyya $\mathrm{N}$. The utility of fine needle aspiration in parotid malignancy. Otolaryngol Head Neck Surg, 2007, 136, 793-798.

57. Luna MA. Salivary glands. W: Head and Neck Surgical pathology. Pilch BZ [red.] Lippincott Williams \& Wilkins, 2000.

58. Mancuso TF, Brennan MJ. Epidemiological considerations of cancer of the gallbladder, bile ducts and salivary glands in the rubber. J Occup Med, 1970, $12,333-341$.

59. Martinelli M, Martini F, Rinaldi E, Caramanico L, Magri E, Grandi E, Carinci F, Pastore A, Tognon M. Simian virus 40 sequences and expression of the viral large $\mathrm{T}$ antigen oncoprotein in human pleomorphic adenomas of parotid glands. Am J Pathol, 2002, 161, 1127-1133. 
60. Matsuba HM, Thawley SE, Devineni VR, Levine LA, Smith PG. High-grade malignancies of the parotid gland: effective use of planned combined surgery and irradiation. Laryngoscope, 1985, 95, 1059-1063.

61. McGuirt WF, Keyes JW Jr, Greven KM, Williams DW 3rd, Watson NE Jr, Cappellari JO. Preoperative identification of benign versus malignant parotid masses: a comparative study including positron emission tomography. Laryngoscope, 1995, 105, 579-584.

62. Mihailescu D, Shore-Freedman E, Mukani S, Lubin J, Ron E, Schneider AB. Multiple neoplasms in an irradiated cohort: pattern of occurrence and relationship to thyroid cancer outcome. J Clin Endocrinol Metab, 2002, 87, 32363241.

63. Milham SJr . Cancer mortality pattern associated with exposure to metals. Ann N Y Acad Sci, 1976, 271, 243-249.

64. Miller AS, Harwick RD, Alfaro-Miranda M, Sundararajan M. Search for correlation of radon levels and incidence of salivary gland tumors. Oral Surg Oral Med Oral Pathol, 1993, 75, 58-63.

65. Modan B, Chetrit A, Alfandary E, Tamir A, Lusky A, Wolf M, Shpilberg O. Increased risk of salivary gland tumors after low-dose irradiation. Laryngoscope, 1998, 108, 1095-1097.

66. Muscat JE, Wynder EL. A case/control study of risk factors for major salivary gland cancer. Otolaryngol Head Neck Surg, 1998, 118, 195-198.

67. Nagao K, Matsuzaki O, Saiga H, Sugano I, Shigematsu H, Kaneko T, Katoh T, Kitamura T. Histopathologic studies of undifferentiated carcinoma of the parotid gland. Cancer, 1982, 50, 1572-1579.

68. Nagao T, Gaffey TA, Olsen KD, Serizawa H, Lewis JE. Small cell carcinoma of the major salivary glands: clinicopathologic study with emphasis on cytokeratin 20 immunoreactivity and clinical outcome. Am J Surg Pathol, 2004, 28, 762-770.

69. Nascimento AG, Amaral AL, Prado LA, Kligerman J, Silveira TR. Adenoid cystic carcinoma of salivary glands. A study of 61 cases with clinicopathologic correlation. Cancer, 1986, 57, 312-319.

70. Nascimento AG, Amaral LP, Prado LA, Kligerman J, Silveira TR. Mucoepidermoid carcinoma of salivary glands: a clinicopathologic study of 46 cases. Head Neck Surg, 1986, 8, 409-417. 
71. Nouraei SA, Hope KL, Kelly CG, McLean NR, Soames JV. Carcinoma ex benign pleomorphic adenoma of the parotid gland. Plast Reconstr Surg, 2005, 116, 1206-1213.

72. Numata T, Muto H, Shiba K, Nagata H, Terada N, Konno A Evaluation of the validity of the 1997 International Union Against Cancer TNM classification of major salivary gland carcinoma. Cancer, 2000, 89, 1664-1669.

73. Olejniczak I, Kozłowski Z, Dabrowska K, Łukomski M. Guzy ślinianki przyusznej - obraz kliniczny, sposób postępowania i wyniki leczenia. Otolaryngol Pol, 2008, 62, 446-450.

74. Olszański W, Mazurkiewicz M, Gołąbek W, Kłos A. Operacje nowotworów złośliwych ślinianek przyusznych. Otolaryngol Pol, 2000, 54 Supl 31, 278-279.

75. Ostman J, Anneroth G, Gustafsson H, Tavelin B. Malignant salivary gland tumours in Sweden 1960-1989 - an epidemiological study. Oral Oncol, 1997, 33, 169-176.

76. Ożdziński W, Narożny W, Dębniak E, Kozłowski J. Nowotwory złośliwe ślinianki przyusznej. Otolaryngol Pol, 1995, 49 Supl 20, 245-248.

77. Pedersen D, Overgaard J, Søgaard H, Elbrønd O, Overgaard M. Malignant parotid tumors in 110 consecutive patients: treatment results and prognosis. Laryngoscope, 1992, 102, 1064-1069.

78. Perzin KH, Gullane P, Clairmont AC. Adenoid cystic carcinomas arising in salivary glands: a correlation of histologic features and clinical course. Cancer, $1978,42,265-282$.

79. Pietniczka-Załęska M, Kukwa A. Guzy ślinianki przyusznej w materiale Kliniki Otolaryngologii w Warszawie w latach 1990-2006. Otolaryngol Pol, 2008, 62, 395-399.

80. Pohar S, Gay H, Rosenbaum P, Klish D, Bogart J, Sagerman R, Hsu J, Kellman R. Malignant parotid tumors: presentation, clinical/pathologic prognostic factors, and treatment outcomes. Int J Radiat Oncol Biol Phys, 2005, 61, 112 118.

81. Poorten VV, Balm AJ, Hilgers FJ, Tan IB, Loftus-Coll BM, Keus RB, van Leeuwen FE, Hart AA. The development of a prognostic score for patients with parotid carcinoma. Cancer, 1999, 85, 2057-2067.

82. Poorten VV, Balm AJ, Hilgers FJ. Management of cancer of the parotid gland. Curr Opin Otolaryngol Head Neck Surg, 2002, 10, 134-144. 
83. Poorten VV, Hart A, Vauterin T, Jeunen G, Schoenaers J, Hamoir M, Balm A, Stennert E, Guntinas-Lichius O, Delaere P. Prognostic index for patients with parotid carcinoma: international external validation in a Belgian-German database. Cancer, 2009, 115, 540-550.

84. Preston-Martin S, Thomas DC, White SC, Cohen D. Prior exposure to medical and dental X-rays related to tumors of the parotid gland. J Natl Cancer Inst, 1988, 80, 943-949.

85. Rafla S. Malignant parotid tumors: natural history and treatment. Cancer, 1977, 40, 136-144.

86. Régis De Brito Santos I, Kowalski LP, Cavalcante De Araujo V, Flávia Logullo A, Magrin J. Multivariate analysis of risk factors for neck metastases in surgically treated parotid carcinomas. Arch Otolaryngol Head Neck Surg, 2001, 127, 56-60.

87. Ron E, Saftlas AF. Head and neck radiation carcinogenesis: epidemiologic evidence. Otolaryngol Head Neck Surg, 1996, 115, 403-408.

88. Sadetzki S, Oberman B, Mandelzweig L, Chetrit A, Ben-Tal T, Jarus-Hakak A, Duvdevani S, Cardis E, Wolf M. Smoking and risk of parotid gland tumors: a nationwide case-control study. Cancer, 2008, 112, 1974-1982.

89. Saw D, Lau WH, Ho JH, Chan JK, Ng CS. Malignant lymphoepithelial lesion of the salivary gland. Hum Pathol, 1986, 17, 914-923.

90. Seifert G, Miehlke A, Haubrich J, Chilla R. Diseases of the Salivary Glands: Pathology - Diagnosis - Treatment- Facial Nerve Surgery. Thieme PublishingGroup, Stuttgart, 1986.

91. Seifert G, Sobin LH. Histological typing of salivary gland tumours. W: World Health Organization. International classification of tumours. Springer-Verlag, Berlin, 1991.

92. Seifert G, Sobin LH. The World Health Organization's Histological Classification of Salivary Gland Tumors. A commentary on the second edition. Cancer, 1992, 70, 379-385.

93. Shapiro NL, Bhattacharyya N. Clinical characteristics and survival for major salivary gland malignancies in children. Otolaryngol Head Neck Surg, 2006, 134, 631-634. 
94. Shemen LJ, Huvos AG, Spiro RH. Squamous cell carcinoma of salivary gland origin. Head Neck Surg, 1987, 9, 235-240.

95. Sobin LH, Wittekind C [red.]. UICC TNM classification of malignant tumours. $5^{\text {th }}$ ed. Wiley, New York, 1997.

96. Sobin LH, Wittekind C [red.]. UICC TNM classification of malignant tumours. $6^{\text {th }}$ ed. Wiley, New York, 2002.

97. Som PM, Shugar JM, Sacher M, Stollman AL, Biller HF. Benign and malignant parotid pleomorphic adenomas: CT and MR studies. J Comput Assist Tomogr, 1988, 12, 65-69.

98. Spiro IJ, Wang CC, Montgomery WW. Carcinoma of the parotid gland. Analysis of treatment results and patterns of failure after combined surgery and radiation therapy. Cancer, 1993, 71, 2699-2705.

99. Spiro JD, Spiro RH. Salivary gland neoplasms. W: Principles and Practice of Head and Neck Oncology. Rhys Evans PH i wsp. [red.]. Martin Dunitz, 2003.

100. Spiro JD, Spiro RH. Cancer of the parotid gland: role of 7th nerve preservation. World J Surg, 2003, 27, 863-867.

101. Spiro RH, Huvos AG, Strong EW. Adenocarcinoma of salivary origin. Clinicopathologic study of 204 patients. Am J Surg, 1982, 144, 423-431.

102. Spiro RH, Huvos AG, Strong EW. Adenoid cystic carcinoma of salivary origin. A clinicopathologic study of 242 cases. Am J Surg, 1974, 128, 512-520.

103. Spitz MR, Sider JG, Newell GR, Batsakis JG. Incidence of salivary gland cancer in the United States relative to ultraviolet radiation exposure. Head Neck Surg, 1988, 10, 305-308.

104. Stennert E, Kisner D, Jungehuelsing M, Guntinas-Lichius O, Schröder U, Eckel HE, Klussmann JP. High incidence of lymph node metastasis in major salivary gland cancer. Arch Otolaryngol Head Neck Surg, 2003, 129, 720-723.

105. Sterman BM, Kraus DH, Sebek BA, Tucker HM. Primary squamous cell carcinoma of the parotid gland. Laryngoscope, 1990, 100, 146-148.

106. Swanson GM, Burns PB. Cancers of the salivary gland: workplace risks among women and men. Ann Epidemiol, 1997, 7, 369-374.

107. Szanto PA, Luna MA, Tortoledo ME, White RA. Histologic grading of adenoid cystic carcinoma of the salivary glands. Cancer, 1984, 54, 1062-1069. 
108. Takeichi N, Hirose F, Yamamoto H, Ezaki H, Fujikura T. Salivary gland tumors in atomic bomb survivors, Hiroshima, Japan. II. Pathologic study and supplementary epidemiologic observations. Cancer, 1983, 52, 377-385.

109. Terhaard C, Lubsen H, Tan B, Merkx T, van der Laan B, Baatenburg de Jong R, Manni H, Knegt P. Facial nerve function in carcinoma of the parotid gland. Eur J Cancer, 2006, 42, 2744-50. Erratum in: Eur J Cancer, 2007, 43, 1883.

110. Terhaard CH, van der Schroeff MP, van Schie K, Eerenstein SE, Lubsen H, Kaanders JH, Smeele LE, Burlage FR, van Den Ende PL, Baatenburg de Jong RJ. The role of radiotherapy in the treatment of malignant salivary gland tumors. Int J Radiat Oncol Biol Phys, 2005, 61, 103-111.

111. Thackray AC, Sobin LH. Histological typing of salivary gland tumours. W: World Health Organization. International classification of tumours. The organization, Geneva, 1972.

112. Theriault C, Fitzpatrick PJ. Malignant parotid tumors. Prognostic factors and optimum treatment. Am J Clin Oncol, 1986, 9, 510-516.

113. Tsai CC, Chen CL, Hsu HC. Expression of Epstein-Barr virus in carcinomas of major salivary glands: a strong association with lymphoepithelioma-like carcinoma. Hum Pathol, 1996, 27, 258-262.

114. Tullio A, Marchetti C, Sesenna E, Brusati R, Cocchi R, Eusebi V. Treatment of carcinoma of the parotid gland: the results of a multicenter study. J Oral Maxillofac Surg, 2001, 59, 263-270.

115. Uchida Y, Minoshima S, Kawata T, Motoori K, Nakano K, Kazama T, Uno T, Okamoto Y, Ito H. Diagnostic value of FDG PET and salivary gland scintigraphy for parotid tumors. Clin Nucl Med, 2005, 30, 170-176.

116. Wahlberg P, Anderson H, Biörklund A, Möller T, Perfekt R. Carcinoma of the parotid and submandibular glands-a study of survival in 2465 patients. Oral Oncol, 2002, 38, 706-713.

117. Webb AJ. Cytologic diagnosis of salivary gland lesions in adult and pediatric surgical patients. Acta Cytol, 1973, 17, 51-58.

118. Wierzbicka M, Szyfter W, Bień S, Maciejewski B, Składowski K, Milecki P. Zalecenia diagnostyczno-terapeutyczne dla wybranych nowotworów głowy i szyi. Guzy gruczołów ślinowych. Współcz Onkol, 2006, 5, 220-222. 
119. Williams RR, Horm JW. Association of cancer sites with tobacco and alcohol consumption and socioeconomic status of patients: interview study from the Third National Cancer Survey. J Natl Cancer Inst, 1977, 58, 525-547.

120. Witten J, Hybert F, Hansen HS. Treatment of malignant tumors in the parotid glands. Cancer, 1990, 65, 2515-2520.

121. Wong DSY. Signs and symptoms of malignant parotid tumours: an objective assessment. J R Coll Surg Edinb, 2001, 46, 91-95.

122. Yonetsu K, Ohki M, Kumazawa S, Eida S, Sumi M, Nakamura T. Parotid tumors: differentiation of benign and malignant tumors with quantitative sonographic analyses. Ultrasound Med Biol, 2004, 30, 567-574.

123. Zbären P, Guélat D, Loosli H, Stauffer E. Parotid tumors: Fine-needle aspiration and/or frozen section. Otolaryngol Head Neck Surg, 2008, 139, 811-815.

124. Zbären P, Schüpbach J, Nuyens M, Stauffer E, Greiner R, Häusler R. Carcinoma of the parotid gland. Am J Surg, 2003, 186, 57-62.

125. Zurrida S, Alasio L, Tradati N, Bartoli C, Chiesa F, Pilotti S. Fine-needle aspiration of parotid masses. Cancer, 1993, 15, 2306-2311.

Dziękuję dr Piotrowi Wiśniewskiemu z Kliniki Endokrynologii i Chorób Wewnętrznych Uniwersytetu Medycznego w Gdańsku za pomoc w obliczeniach statystycznych i przygotowaniu rycin. 